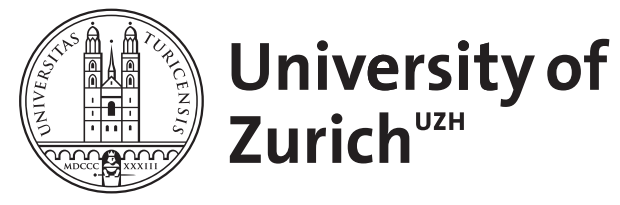

Zurich Open Repository and Archive

University of Zurich

University Library

Strickhofstrasse 39

CH-8057 Zurich

www.zora.uzh.ch

Year: 2010

A generic classification of the Restioneae (Restionaceae), southern Africa

Linder, H P ; Hardy, C R

DOI: https://doi.org/10.4102/abc.v40i1.178

Posted at the Zurich Open Repository and Archive, University of Zurich

ZORA URL: https://doi.org/10.5167/uzh-42745

Journal Article

Published Version

Originally published at:

Linder, H P; Hardy, C R (2010). A generic classification of the Restioneae (Restionaceae), southern Africa. Bothalia, 40(1):1-35.

DOI: https://doi.org/10.4102/abc.v40i1.178 


\title{
A generic classification of the Restioneae (Restionaceae), southern Africa
}

\author{
H.P. LINDER* and C.R. HARDY**
}

Keywords: Africa, generic classification, Restionaceae, Restioneae, taxonomy

\author{
ABSTRACT
}

We propose a new generic classification of the African Restionaceae, tribe Restioneae (subfamily Restionoideae), based on the phylogeny and on extensive morphological data. The phylogeny is based on both plastid sequence data and morphological data. We delimit the genera to be monophyletic, to minimize the nomenclatural changes, and to maximize the ability to diagnose the genera. We recognize eight genera, one of which with nine subgenera, in the tribe. Of the currently accepted genera, only three need changes. We provide descriptions for all genera and subgenera, and include a key to them. In this paper we erect one new genus, Soroveta, redelimit Platycaulos and Restio, and reduce Calopsis and Ischyrolepis to synonomy under Restio. We list the species which we recognize under each genus, make 37 new combinations, propose eight new names, and also describe eight new species that belong in these genera.

\section{CONTENTS}

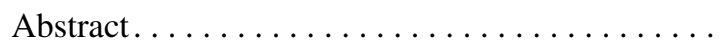

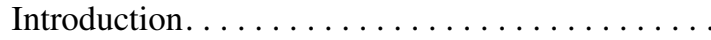

Delimiting genera $\ldots \ldots \ldots \ldots \ldots \ldots \ldots \ldots$

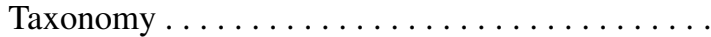

Artificial key to genera of Restioneae. . . . . . . . .

Soroveta-Platycaulos grade ...............

1. Soroveta .......................

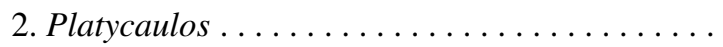

Staberoha-Elegia clade ................

3. Staberoha ......................

4. Thamnochortus ...................

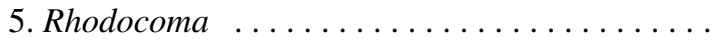

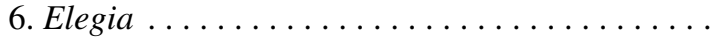

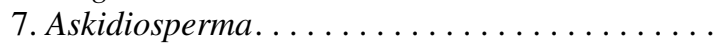

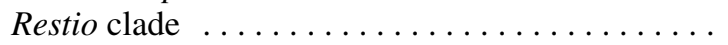

8. Restio. ......................

8.1 subgen. Simplicaulos . . . . . . . . . . .

8.2 subgen. Pendulostemon ...............

8.3 subgen. Craspedolepis . . . . . . . . . . .

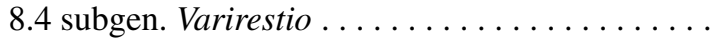

8.5 subgen. Calopsis . . . . . . . . . . . . . . . . .

8.6 subgen. Eremorestio . . . . . . . . . . . . . . .

8.7 subgen. Restio . . . . . . . . . . . . . . . . . . . . . . .

8.8 subgen. Locapsis . . . . . . . . . . . . . . . .

8.9 subgen. Ischyrolepis . . . . . . . . . . . . .

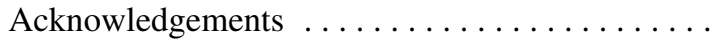

References ....................

Index . . . . . . . . . . . . . . . . . .

\section{INTRODUCTION}

The African Restionaceae (subfam. Restionoideae, \pm 350 species) comprise one of the dominant elements of the fynbos vegetation of the Cape Floristic Region (CFR,

\footnotetext{
* Institute of Systematic Botany, University of Zurich, Zurich 8008 , Switzerland.

** James C. Parks Herbarium, Department of Biology, Millersville University, P.O. Box 1002, Millersville, PA 17551, USA/Department of Botany, MRC-166, National Museum of Natural History, Smithsonian Institution, P.O. Box 37012, Washington, DC 20013, USA. MS. received: 2009-09-23.
}

Goldblatt 1978) (Taylor 1978; Rebelo et al. 2006), and is regarded as one of the most important clades of the larger Cape flora (Linder 2003). Within the African Restionaceae, the tribe Restioneae (Briggs \& Linder 2009) includes most species (288), all of which are endemic to sub-Saharan Africa or Madagascar. A user-friendly, maximally informative generic classification of the tribe is thus essential for the effective study of the Cape flora.

The taxonomy of the Restioneae has been investigated several times over the past centuries, using different data sets and different taxonomic concepts. Most of the publications from the 19th and 20th centuries were concerned with describing the many species which were brought to Europe by early collectors: for a summary, see Linder (1985). However, several publications also focused on the generic delimitations. In the 19th century, the morphology of the species was the primary evidence on which the generic delimitation was based, resulting in the classification proposed by Masters $(1878 ; 1897)$ and used by Pillans (1928). This was based heavily on the gynoecial characters and remained in use until 1984 (Adamson \& Salter 1950; Dyer 1976). Citing problems with the Masters classification, Gilg-Benedict (1930) based an alternative classification on the culm anatomical data of her husband, Gilg (1891), but this classification was unfortunately ignored. By 1980 it was evident that there were two major problems with the Masters-Pillans generic classification. Firstly, it did not effectively summarize the new anatomical and palynological data, and so was not natural in a phenetic sense. Secondly, many of the genera were clearly based on plesiomorphic features, and so could not be monophyletic. In 1984, Linder proposed a new generic classification, incorporating a much wider data base than had previously been used-including anatomical (Gilg 1891; Cutler 1969), palynological (Chanda 1966; Chanda \& Rowley 1967; Linder \& Ferguson 1985), and phytochemical (Harborne \& Clifford 1969; Harborne 1979; Harborne et al. 1985) data in addition to morphology. He also attempted to define monophyletic genera. However, this classification still contained problems. Firstly, the data sampling was not complete, and the eventual classification proposed was based on the congruence of partial data-set-specific cladograms. Secondly, for 
several genera, no explicit morphological or anatomical synapomorphies could be identified, and so these genera could not be justified in a classic Hennigian sense. The first set of problems was in the Elegia clade, where Chondropetalum lacked synapomorphies. Moline \& Linder (2005) solved this problem by combining Chondropetalum, Elegia and Dovea. The next set of problems was in the Restio clade. Under Restio, Linder noted: 'However, it is still not possible to demonstrate that Restio, as delimited here, is monophyletic'. Under Calopsis, Linder noted: 'the exact boundary between Restio and Calopsis is not yet resolved'. These problems remain unresolved.

Recently, Hardy et al. (2008) published an almost completely sampled phylogeny of the African Restionaceae (subfam. Restionoideae), expanding the previously published phylogeny for the nested Elegia group (Moline \& Linder 2005) to include a complete species sampling of the entire tribe Restioneae (Figures 1-5). This study corroborated earlier indications from a much more sparsely sampled phylogeny (Eldenäs \& Linder 2000) that several genera were para- or polyphyletic. It also provided the sampling density that enabled a test of the monophyly of all previously recognized genera, as well as the discovery of many new clades, some of which warrant description as new taxa. As such, the objective of this article is to integrate this new information into a revised generic classification of the Restioneae. In order to facilitate the use of the new generic classification, we list the species accepted under each genus and subgenus, and we simultaneously make all necessary new combinations, and formally describe several as yet undescribed species.

\section{DELIMITING GENERA}

\section{Theoretical criteria}

The criteria for the circumscription and ranking of genera have received little attention and most authors simply indicate that they follow the criteria proposed by Backlund \& Bremer (1998). These were expanded by Humphreys \& Linder (2009), who argued for larger genera, more consistent with the generic concept used by Bentham \& Hooker in Genera plantarum. Thus, genera are not necessarily the smallest monophyletic or diagnosable groups. These, they suggest, may be better recognized by formal infrageneric taxa. Our classification that follows represents our attempt to optimize our adherence to the following criteria: 1 , monophyly; 2 , diagnosability; 3, nomenclatural stability; and 4, informativeness.

1. Monophyly. All genera and subgenera recognized here, were resolved as (potentially) monophyletic (i.e. as clades) by Hardy et al. (2008; summarized in Figures 15). Monophyletic taxa contain a closed segment of evolutionary history; therefore, such taxa can be expected to have a much greater predictive power than taxa that are not monophyletic. Furthermore, monophyletic taxa are more comparable for evolutionary studies or conservation efforts which seek to account for phylogenetic diversity in addition to species diversity in management decisions.

However, in this context monophyly refers to the 'true' phylogeny. The data collected by phylogeneticists only allow us to estimate this phylogeny. These estimates con- tain several sources of error, two of which are pertinent to our study. Firstly, different genome partitions may reflect different phylogenetic histories (Doyle 1992; Maddison 1997). Such incongruent phylogenetic histories may result from the transfer of a chloroplast from one species to another during hybridization. In this case, a phylogeny based on the chloroplast plastid genome may not reflect the phylogeny of the nuclear genome. The second error may occur when stochastic variation in DNA base pairs results in the retrieval of clades. In this case, the shared DNA base pairs that lead to the retrieval of a clade are not the result of a common history. An extreme, and possibly quite rare form of this phenomenon results in long branch attraction (Felsenstein 1978). Much more common are nodes with relatively little statistical support.

The phylogenetic inferences of Hardy et al. (2008) were based on both parsimony and Bayesian analysis of a moderately large dataset consisting of plastid DNA sequences $( \pm 7.3 \mathrm{~Kb})$ and 150 morphological and anatomical characters for all 292 species and subspecies of the Restioneae. The robustness of these inferences, however, is limited by the inability of Hardy et al. (2008) to successfully generate nuclear DNA sequences. As such, the phylogenetic inferences of Hardy et al. (2008) were strongly influenced by evolutionary history of the plastid genome which, because of problems associated with phenomena such as introgressive hybridization (e.g. chloroplast capture) or lineage sorting, may not faithfully reflect the organismal phylogeny in all aspects (Doyle 1992; Maddison 1997). Additionally, a plastid-specific bias or imbalance in molecular evolutionary rates across the phylogeny could result in phylogenetic error unchecked by another, unlinked nuclear DNA dataset (e.g. Felsenstein 1978; Doyle 1992). Although the morphological and anatomical data are thought to provide phylogenetic signal under the influence of the nuclear genome and therefore independent of the plastid dataset, the relatively large size of the plastid dataset may have had a disproportionate influence on the resulting phylogenetic inferences. However, because the addition of our morphological data to the plastid data in a combined analysis resulted in increased support (via bootstrap and posterior probabilities) for most clades than did either data set alone (Hardy et al. 2008), we are confident that the phylogeny is a good approximation of the species phylogeny.

A second problem with our phylogeny is that several of the deeper nodes from the strict consensus trees have very low bootstrap support. This could mean that these nodes will not be retrieved if a larger dataset were to be generated.

2. Diagnosability. In addition to monophyletic groups, we sought to recognize genera that were diagnosable morphologically. Essential and differential morphological attributes can also be used for the assignation of species to the genera, and to develop a morphological concept of a genus. These characters were sought by using the parsimony options in Mesquite (Maddison \& Maddison 2003) to optimize the morphological and anatomical character matrix used in Hardy et al. (2008; available at http://herbarium.millersville.edu/pubs-support.php) over the complete cladogram from Hardy et al. (2008). We defined as diagnostic characters those character states that were optimized to the crown-node (base) of each clade that could be treated as a genus or subgenus, i.e. we ignored variation 
within the clade. We then coded these diagnostic characters (Table 1) for the clades into a new matrix (Table 2) and then mapped them onto a summary tree of the clades (Figure 1) using CLADOS (Nixon 1993). Morphological concepts and states were largely as used by Linder (1984), and are explained, illustrated, and fully documented in the interactive key to the species (Linder 2001a) (http://www. systbot.uzh.ch/Bestimmungsschluessel/Restionaceae. html). Species for which molecular data were not available (20 out of 289) were placed on the basis of morphological and anatomical data, by their inclusion in a cladistic analysis with the full data set. Essential and differential morphological and anatomical attributes were extracted from the morphological data set for each postulated clade. Essential attributes are typical (albeit sometimes with exceptions) of each clade, but not unique to it. Differential attributes, often as combinations of characters, are unique to each clade, and can be used to diagnose the clades. Differential attributes can be used to assign previously unstudied species to their appropriate clades.

A second important component of diagnosability is the ability of users to be able to assign species to the right genus without too complex a procedure, ideally even without having to use a hand-lens. Thus diagnosability that is only possible on anatomical attributes is not optimal.

3. Nomenclatural stability. Genera should be recognized at nodes that will minimize nomenclatural changes. Nomenclatural changes fall into three elements. Firstly, minimizing the number of new combinations: these are most common when genera are divided into segregate genera; in these instances the specific epithet stays the same. Secondly, reducing the number of new names that need to be proposed: these are most common when genera are combined, and result when a specific epithet is already occupied; these are much more confusing than new combinations, as the species now has a completely

TABLE 1.-Selected generic and subgeneric characters mapped onto trees in Figure 1. Character numbers above branch and state of character below branch

1. Culms: round or flattened $=0$; square or angular $=1$.

2. Culms branching: simple $=0$; branching $=1$.

3. Culms: round $=0$; compressed $=1$.

4. Sheaths apical half: as lower part $=0$; membranous and decaying $=1$.

5. Membranous sheath shoulders: absent $=0$; present $=1$.

6. Sheaths: persistent $=0$; caducous $=1$.

7. Floral bract apices: like body $=0$; with hollow cells $=1$.

8. Floral bracts: overtopping flowers $=0$; shorter than flowers $=1$.

9. Floral bracts: chartaceous, cartilaginous or bony $=0$; membranous $=1$.

10. Floral bracts transverse pitting: absent $=0$; present $=1$.

11. Male spikelets: erect $=0$; pendulous $=1$.

12. Anthers at anthesis: exserted from flowers $=0$; included in the flowers $=1$.

13. Female tepals (indumentum): glabrous $=0$; villous $=1$.

14. Female tepals (texture): papery (flexible, not transparent) $=1$; bony or cartilaginous (stiff) $=2$.

15. Female lateral tepals: as odd tepal $=0$; conduplicate $=1$; winged $=2$. [additive]

16. Number of styles: $1=0 ; 2=1 ; 3=2$. [additive].

17. Styles: free or on a stylopodium $=0$; fused to form a peg $=1$.

18. Number of ovary locules: $1=0 ; 2=1 ; 3=2$. [additive].

19. Ovary: dehiscent $=0$; indehiscent $=1$.

20. Central ground tissue cavities: none $=0 ;$ single $=1$; many $=2$. [additive]. different name (both genus and species have changed). Thirdly, frequent changes in the combinations: this results when there is a frequent changing of the generic concepts. In some circumstances no new formal names are required, but from the user point of view there are still changes.

A second consideration should be not only to minimize the number of nomenclatural changes required, but also to consider the nomenclatural consequences of future changes in our understanding of the phylogeny. Ideally, genera should be erected at nodes which are likely to remain robust to future additional data, be it new species or new data sources. Theoretically, at least, larger genera should be less sensitive to smaller changes in the phylogenetic hypothesis.

4. Informativeness. Genera should have a morphological and ecological 'coherence', and not consist of mere collections of species that happen to share a plastid genome. This maximizes the number of attributes that we can assign to a genus, and makes the genus concept more useful.

\section{Genera in the Restioneae}

With the cladistic and morphological data available for the Restioneae, several generic classifications for the Restioneae are possible. In order to facilitate the discussion here, we refer to the names of clades described later in the paper.

1. The maximal option is to include the whole subtribe in one genus. This genus would be strongly supported as being monophyletic by the plastid data (Eldenäs \& Linder 2000; Hardy et al. 2008), but would be difficult to diagnose, as the morphological characters separating Willdenowieae and Restioneae are cryptic anatomical and palynological attributes (Linder 1984), and the clade has no diagnostic attributes. The characters listed in Figure 1 as synapomorphies for the clade (the numbers of styles and carpels), should actually be listed under the Willde-

TABLE 2.-Matrix-representation of distribution of diagnostic or distinctive characters from Table 1 for proposed genera and subgenera of tribe Restioneae. Polymorphism codes as follows: $\mathrm{A}=$ states 0 and $1 ; \mathrm{B}=$ states 1 and $2 ; \mathrm{C}=$ states 0 and 2

\begin{tabular}{|c|c|c|c|c|}
\hline & 5 & 10 & 15 & 20 \\
\hline & & & & \\
\hline Willdenowieae & \multicolumn{4}{|c|}{0100000000000201001100} \\
\hline Soroveta & \multicolumn{4}{|c|}{0100000001000202010100} \\
\hline Platycaulos & \multicolumn{4}{|c|}{$01100000000002 \mathrm{~A} 2010000$} \\
\hline Elegia & \multicolumn{4}{|c|}{0000010100010212020001} \\
\hline Staberoha & \multicolumn{4}{|c|}{$00000000001101 \mathrm{~B} 20011 \mathrm{~A} 0$} \\
\hline Askidiosperma & \multicolumn{4}{|c|}{0000010010010212020000} \\
\hline Thamnochortus & \multicolumn{4}{|c|}{0001000000110220001210} \\
\hline Rhodocoma & \multicolumn{4}{|c|}{$00010001001102020202 \mathrm{~A} 0$} \\
\hline Restio subgen. Calopsis & \multicolumn{4}{|c|}{$110000000000 \mathrm{~A} 212001100$} \\
\hline Restio subgen. Craspedolepis & \multicolumn{4}{|c|}{0100001000001212010000} \\
\hline Restio subgen. Eremorestio & \multicolumn{4}{|c|}{$010000000000 \mathrm{~A} 112001000$} \\
\hline Restio subgen. Ischyrolepis & \multicolumn{4}{|c|}{$0100 \mathrm{~A} 000100011111 \mathrm{~A} 0100$} \\
\hline Restio subgen. Locapsis & \multicolumn{4}{|c|}{0100000000001112001100} \\
\hline Restio subgen. Pendulostemon & \multicolumn{4}{|c|}{0100000000100212010100} \\
\hline Restio subgen. Restio & \multicolumn{4}{|c|}{$010010000000 \mathrm{AB} 1200 \mathrm{~A} 100$} \\
\hline Restio subgen. Simplicaulos & \multicolumn{4}{|c|}{0000000000000212010100} \\
\hline Restio subgen. Varirestio & \multicolumn{4}{|c|}{$010000 \mathrm{~A} 00000 \mathrm{~A} 2120 \mathrm{C} 0100$} \\
\hline
\end{tabular}


nowieae - the Restioneae have the ancestral condition of three styles and three carpels. The genus would not be exceptionally large (some 300 species), but would be morphologically very heterogenous. It would require numerous name changes, and would lose on informativeness, as several very distinct genera, such as Elegia, Thamnochortus and Staberoha, would be lost. This broad approach has been followed in several Cape taxa, such as Erica (Oliver 2000) and Disa (Bytebier et al. 2007, 2008).

2. The minimal option is to retain all existing genera that were retrieved as monophyletic (i.e. Askidiosperma, Elegia, Ischyrolepis, Platycaulos, Rhodocoma, Staberoha and Thamnochortus), and split the remainder up into the smallest number of genera based on clades with at least $70 \%$ bootstrap support (named in Figures 1-5 as Restio subgen. Calopsis, Restio subgen. Craspedolepis, Restio subgen. Eremorestio, Restio subgen. Locapsis, Restio subgen. Pendulostemon, Restio subgen. Restio, Restio subgen. Simplicaulos, Restio subgen. Varirestio and Soroveta). Note that Platycaulos is here somewhat unusual, as this genus receives several species misplaced to Restio in the previous classifications. The recognition of more than one genus in the tribe implies that the basal branch leading to Restio ambiguus has to be recognized at generic level (as the genus Soroveta), as the node excluding this species from the rest of the tribe is very strongly supported. This results in 16 genera, all of which are strongly supported as being monophyletic by the combined plastid DNA and morphological datasets, but not all by the morphological dataset alone. There are great difficulties in diagnosing several of these clades. In some instances no essential or differential characters could be found (e.g. Restio subgen. Varirestio), in others (e.g. Restio subgen. Craspedolepis, Restio subgen. Eremorestio, Restio subgen. Locapsis, Restio s.str., Restio subgen. Simplicaulos) there are essential but no differential characters, i.e. they also occur in other genera albeit relatively rarely. As a result we can have a vague concept of the genus, but cannot key it out. Predictably, these smaller genera are mostly morphologically quite homogeneous. This approach requires more than 70 new combinations, but no new names.

The advantage of this approach is that the monophyly of all genera is strongly supported by the available phylogenetic hypothesis. However, there are two problems. The first is that the generic classification will not be user friendly, as it will be difficult to assign species to the genera, either in the field or in a herbarium. Secondly, there is a very heavy reliance on plastid data in the absence of nuclear DNA data (Doyle 1992). Any mistakes in the phylogeny will result in generic redelimitation.

3. The intermediate option is to retain all existing genera that are not proven to be para- or polyphyletic, and not to start with the assumption that all existing genera that are retrieved as monophyletic have to be retained. In this option, the distinctive and well-supported genera Askidiosperma, Elegia, Platycaulos, Rhodocoma, Soroveta, Staberoha and Thamnochortus are retained, and a larger Restio s.lat. is assembled. The major advantage of this option is that the two difficult segregates, Eremorestio and Varirestio, will not be recognized as distinct genera. Due to the structure of the phylogeny, in all these solutions, Ischyrolepis will need to be included in Restio s.lat., together with most species of Calopsis, as the nodes embedding these two genera within Restio s.lat. are strongly supported in the combined analysis. In the morphological phylogeny of Linder (1984) Ischyrolepis was not included in the Restio-Calopsis clade, due to its very different pollen morphology. A major insight from the molecular phylogeny is that the pollen data are not phylogenetically conservative, as a result Ischyrolepis is found to be nested in the Restio-Calopsis clade. Three variants of Restio s.lat. can be proposed:

3a. Include Calopsis s.str., Craspedolepis, Eremorestio, Ischyrolepis, Locapsis, Pendulostemon, Restio s.str., Simplicaulos and Varirestio in one genus. There is weak evidence that this grouping is paraphyletic: in the combined phylogeny, but with no bootstrap support, Pendulostemon groups with the Thamnochortus-Rhodocoma clade, and Simplicaulos with Staberoha). This large genus is easy to diagnose by exclusion (not Rhodocoma, Thamnochortus, Soroveta, Platycaulos, Elegia or Askidiosperma). It is the most conservative approach, requiring statistically significant evidence to dismantle a genus. The disadvantage of this classification is that there is no evidence for the monophyly of the genus Restio s.lat. (but also no evidence that it is not monophyletic). The advantage is that the genus is easy to recognize in the field and herbarium and that it is nomenclaturally conservative (if eventually there is sufficient evidence that to separate Simplicaulos and Pendulostemon will not require undoing a set of nomenclatural changes). The strongly supported monophyletic units can then be recognized as subgenera of Restio s.lat., these should be used for evolutionary investigations.

3b. As above, but retain Simplicaulos and Pendulostemon as distinct genera on the basis that there is weak evidence linking these to Staberoha and Thamnochortus respectively. It removes all evidence that Restio s.lat. could be paraphyletic, but there is also no evidence that the remaining Restio s.lat. is monophyletic. Pendulostemon can be readily diagnosed, but Simplicaulos lacks differential characters. The most important attribute is the unbranched culms: this is a highly variable character. The advantage is that no genera are recognized for which there is (even poorly supported) evidence for paraphyly. The disadvantages are two-fold: due to the low support values, it remains possible that additional datasets will group the two segregates again with Restio s.lat., leading to name changes. Furthermore, one of the two segregate genera cannot be keyed out.

3c. Recognize, in addition to Simplicaulos and Pendulostemon, also Craspedolepis. This leaves the rest of Restio s.lat. with positive (albeit weak) evidence of its monophyly, but it adds another genus that is difficult to diagnose. Frustratingly, Craspedolepis does have a striking essential character, a band of hollow (concave) cells at the apical margins of the floral bracts, but this is in some species poorly developed, and also occurs in a few species outside the genus. It is thus of little use as a differential character.

We follow here option $3 \mathrm{a}$, which recognizes eight genera in the tribe. The eight strictly monophyletic segregates of Restio s.lat. are recognized as subgenera. We hope that this will combine the need for strictly monophyletic taxa for evolutionary analysis (the subgenera), 


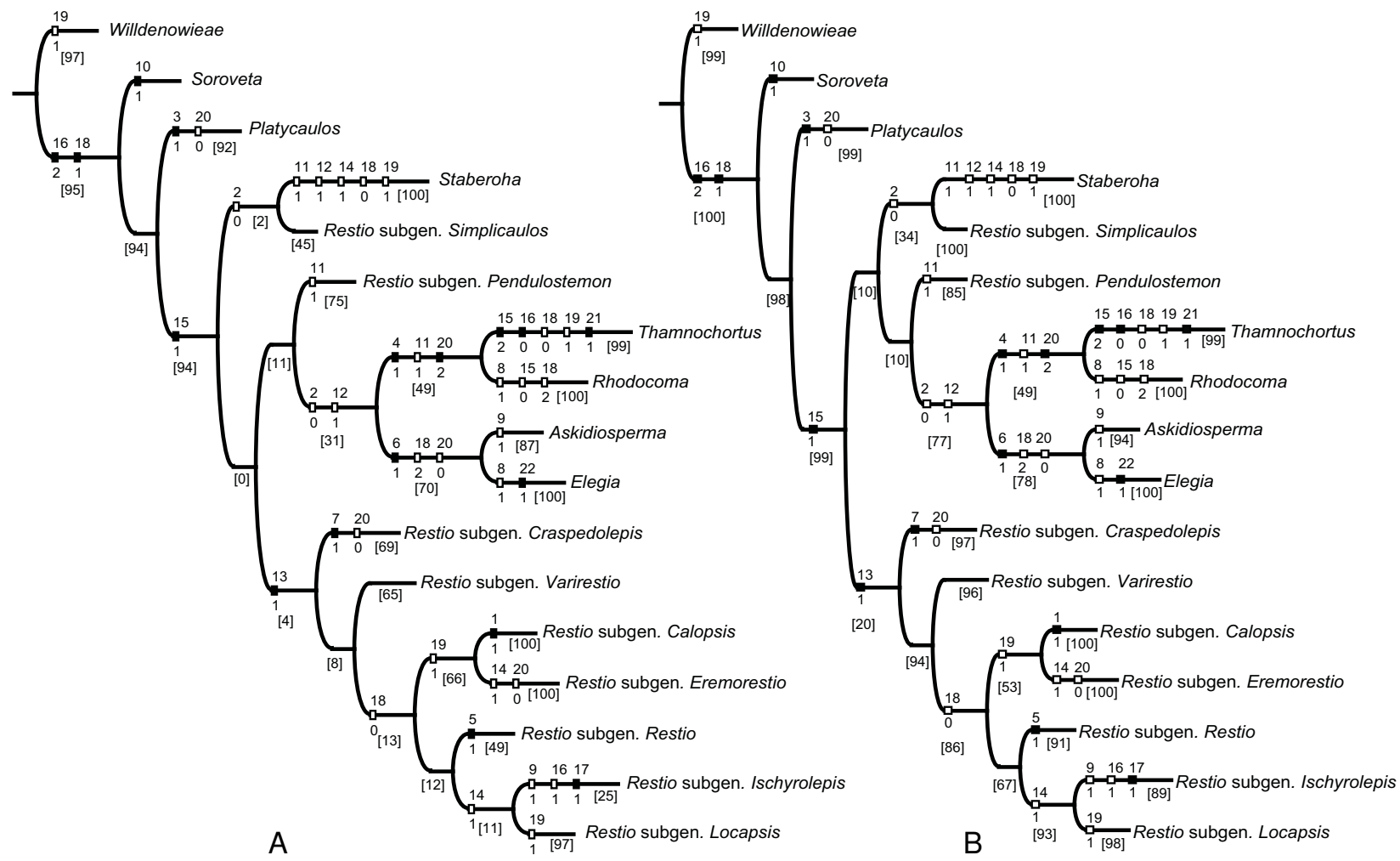

FIGURE 1.-Cladograms summarizing generic and subgeneric relationships in the Restioneae (Hardy et al. 2008). A, relationships in the strict consensus tree from the analysis of all 292 species and subspecies. B, relationships in the strict consensus tree from the analysis of 272 species and subspecies omitting 20 species/subspecies for which DNA data were lacking. Bootstrap percentage values (in square brackets) are based on the analysis of Hardy et al. (2008). Characters from Tables 1 and 2 are optimized using the slow (deltran) options in WinClada: the character number appears above the solid and open squares. The state of the character appears below the solid and open squares. An open square indicates a character that evolved at least twice, whereas a solid quare indicates a character that evolved only once.

with easy-to-recognize, nomenclaturally stable genera. It is important, though, that no taxa that are demonstrably para- or polyphyletic be recognized.

\section{TAXONOMY}

The full nomenclature and synonymy of the species is not repeated: it was published in 1985, consequently only the accepted species and their place of publica- tion is given. However, for the new combinations, the basionym and the type is indicated, as required. Again no full synonymy is presented. The complete synonymy, descriptions, illustrations to all species, and an interactive key is available online at http://www.systbot.uzh. ch/Bestimmungsschluessel/Restionaceae.html, or can be bought as a CD from the Bolus Herbarium, University of Cape Town. The species are presented in a 'natural' sequence, partially based on the phylogeny, partially based on their similarity.

\section{Artificial key to genera of Restioneae}

1a Floral bracts reddish brown, bony, with transverse lacunae

2a Male spikelets pendulous:

3a Ovary indehiscent; diaspore a nut enclosed in a persistent, papery to cartilaginous, perianth, which may be winged:

4a Male spikelets linear-oblong; female flowers with a single style exserted from floral bracts; perianth a firm winged or keeled structure; sheaths decaying in upper half $\ldots \ldots \ldots \ldots \ldots \ldots \ldots \ldots \ldots \ldots \ldots \ldots \ldots \ldots \ldots \ldots \ldots \ldots \ldots \ldots \ldots \ldots \ldots$ Thamnocho

4b Male spikelets \pm globose; females with 1-3 styles obscured behind floral bracts; perianth papery, sometimes keeled; sheath apical

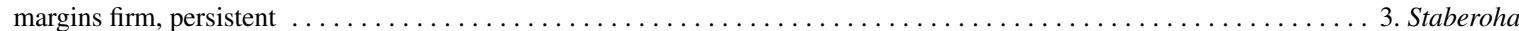

3b Ovary dehiscent; diaspore a seed:

5a Culms branching; female floral bracts taller than flowers, often with longitudinal striations . . . . . . . 8.2 Restio subgen. Pendulostemon

5 b Culms simple (except for $R$. capensis, where culms have whorled branches); female floral bracts shorter than flowers, never with

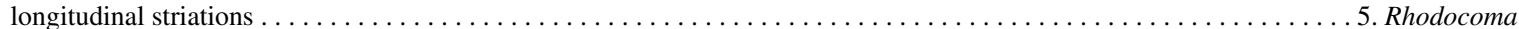
2b Male spikelets erect:

6a Sheaths falling off, sometimes somewhat tardily so, leaving a distinct dehiscence ring:

7a Floral bracts membranous, much taller than flowers; ovary dehiscent or tardily indehiscent . . . . . . . . . . . . 7. Askidiosperma

$7 \mathrm{~b}$ Floral bracts leathery to bony, rarely taller than flowers, mostly shorter; ovary either dehiscent or indehiscent ............ $6 .$. Elegia $6 \mathrm{~b}$ Sheaths persistent:

8a Culms laterally compressed (sometimes only at apex); sheaths with stout mucro, both same green colour as culm, usually with

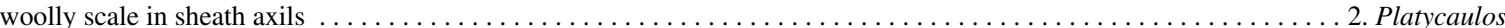


8b Culms round; if laterally compressed then sheaths brown, clearly different from culm, and without woolly scales:

9a Female inflorescences of numerous poorly organized spikelets arranged at several nodes; bracts not obscuring flowers; spathes

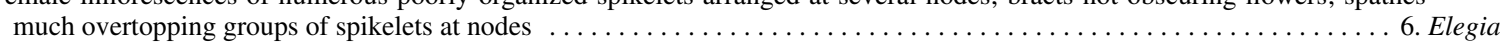

9b Female inflorescences of one to many well-organized spikelets, either racemosely or paniculately organized; bracts mostly obscuring flowers; spathes at most as tall as spikelets (Restio s.lat.):

10a Culms square or otherwise angular in cross section; plants $1 \mathrm{~m}$ or taller; inflorescences large, paniculate, with very numerous spikelets $\ldots \ldots \ldots \ldots \ldots \ldots \ldots \ldots \ldots \ldots \ldots \ldots \ldots \ldots \ldots \ldots \ldots \ldots \ldots \ldots \ldots \ldots \ldots \ldots \ldots \ldots \ldots \ldots \ldots \ldots \ldots$ Restio subgen. Calopsis

$10 \mathrm{~b}$ Culms round, terete or compressed (flattened) in cross section; plants variable in height, but often less than $1 \mathrm{~m}$; inflorescence rarely very large:

11a Style branches two, fused below into persistent stylar peg; ovary always dehiscent . . . . . . . . 8.9 Restio subgen. Ischyrolepis

11 b Style branches 1,2 or 3, never fused into persistent stylar peg; ovary either dehiscent or indehiscent:

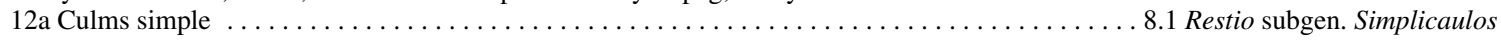

12b Fertile culms branched:

13a Floral bracts with upper margin markedly different from bract body, consisting of hollow cells; ovary usually bilocular, dehiscent $\ldots \ldots \ldots \ldots \ldots \ldots \ldots \ldots \ldots \ldots \ldots \ldots \ldots \ldots \ldots \ldots \ldots \ldots \ldots \ldots \ldots \ldots$ Restio subgen. Craspedolepis

13b Floral bracts without such upper margins; ovary various:

14a Female perianth papery, truncate or rounded; ovary indehiscent, unilocular:

15a Female floral bracts acuminate, apices somewhat recurved, darker than bract body; sheaths always tightly rolled around culms; nuts triangular, more than $2 \mathrm{~mm}$ long $\ldots \ldots \ldots \ldots \ldots \ldots \ldots \ldots \ldots$ Restio subgen. Eremorestio 15b Female floral bracts acute, apices erect, same colour as body of bracts; sheaths mostly spreading, sometimes tightly rolled around the culms; nuts various $\ldots \ldots \ldots \ldots \ldots \ldots \ldots \ldots \ldots \ldots \ldots \ldots \ldots \ldots \ldots$ Restio subgen. Locapsis $14 \mathrm{~b}$ Female perianth coriaceous or bony, acute; ovary indehiscent or dehiscent, with 1 , 2 , or 3 locules:

16a Ovary with 1 or 3 locules; sheath awn sometimes as long as sheath; sheaths with poorly developed membranous lobes $\ldots \ldots \ldots \ldots \ldots \ldots \ldots \ldots \ldots \ldots \ldots \ldots \ldots \ldots \ldots \ldots \ldots \ldots \ldots \ldots \ldots \ldots \ldots \ldots \ldots \ldots$ Restio subgen. Varirestio 16b Ovary with 1 or 2 , rarely 3 locules; sheath awn shorter than sheath $\ldots \ldots \ldots \ldots \ldots \ldots \ldots \ldots \ldots . \ldots \ldots$ Restio subgen. Restio

\section{Soroveta-Platycaulos grade}

An expanded Platycaulos and the newly erected genus Soroveta H.P.Linder \& C.R.Hardy, gen. nov., comprise a relatively species-poor grade within the Restioneae that is paraphyletic to the remainder of the Restioneae (Figures 1-5). The monotypic Soroveta is rather isolated and does not share any particularly striking morphological characteristics with Platycaulos. Perhaps their greatest resemblances lie in their native habitats, where both characteristically grow in areas of impeded drainage or summer rainfall, although the two genera do not co-occur.

1. Soroveta H.P.Linder \& C.R.Hardy, gen. nov., ab aliis generibus tribus Restioneae bracteis floralibus transversaliter foveatis et combinatione vaginorum persistentium cum tepalis uniformibus distinguendum.

TYPE.—Soroveta ambigua (Mast.) H.P.Linder \& C.R. Hardy.

Plants clumped. Fertile culms sparsely branched, round; sheaths persistent, closely convoluted, margins coriaceous, without hyaline shoulders. Male inflorescence racemose; spikelets $1-5$, erect, several-flowered; spathes persistent, shorter than spikelets; bracts dark brown, with transverse pitting; anthers exserted from flowers. Female inflorescence and spikelets similar to males, with 1-5 linear or oblong, acute, 2-8-flowered spikelets; flowers not laterally compressed; tepals chartaceous or cartilaginous, scabrid all over, outer lateral tepals not differentiated from outer odd tepal; staminodes present. Gynoecium with 3 white, feathery styles free to base; ovary bilocular, dehiscent. Seed brown, pitted. Culm anatomy: epidermal cells single-layered, lateral radial wall straight, unthickened; chlorenchyma two-layered, stomatal cavities with protective cells; parenchymatous layer between chlorenchyma and sclerenchyma of 3-5 cells; central ground tissue with single, central cavity; tannin and silica absent.

Etymology: Soroveta (f.): soror (Latin: f., III), sister; vetus (Latin), ancient; referring to the topological position of the genus, as the sister to the rest of Restioneae (Figure 2).

Notes: the isolated position of this species was already recognized by Masters (1897) who gave it the very prescient specific epithet. Morphologically, the species shows several unusual features in the male and female inflorescences, notably resembling Elegia in the naked female flowers without any lateral (dorsiventral) flattening, but without the caducous sheaths and other attributes typical of that clade. Furthermore, the dark brown floral bracts with transverse pitting are unique in the subfamily. However, there are no obvious synapomorphies for the rest of the Restioneae, consequently the basal position of this species cannot be detected morphologically. In the absence of molecular data, the species would probably have been retained as a highly specialized species of Restio.

1.1. Soroveta ambigua (Mast.) H.P.Linder \& C.R. Hardy, comb. nov.

Restio ambiguus Mast. in Flora capensis 7: 96 (1897). Type: Cape, s.loc., Zeyher s.n. (K, holo.!; B!).

2. Platycaulos H.P.Linder in Bothalia 15: 64 (1984). Type: Platycaulos compressus (Rottb.) H.P.Linder.

Plants tufted, tangled or mat-forming. Fertile culms branching, more or less compressed, though sometimes only near apex; sheaths persistent, with no abscission line, closely convoluted, usually densely textured and same colour as culms, apical margins narrowly membranous, continuing behind the stout, awl-like awn. Male inflorescence racemose or paniculate with up to 20 sessile or stiffly erect, often distichous spikelets; spathes persistent or caducous; male bract with upper margin like body of bract; anthers exserted from flowers. Female inflorescence with 1-10 spikelets; spikelets 1-15-flowered, variously shaped; bracts at least as tall as flowers, often much taller, mostly cartilaginous, apical margin like rest of bract; imbricate and obscuring spikelet axis; tepals chartaceous or cartilaginous, glabrous or keels of lateral sepals villous; staminodes present. Gynoecium with 3 white, feathery styles free to base; ovary with 1 or 2 fer- 


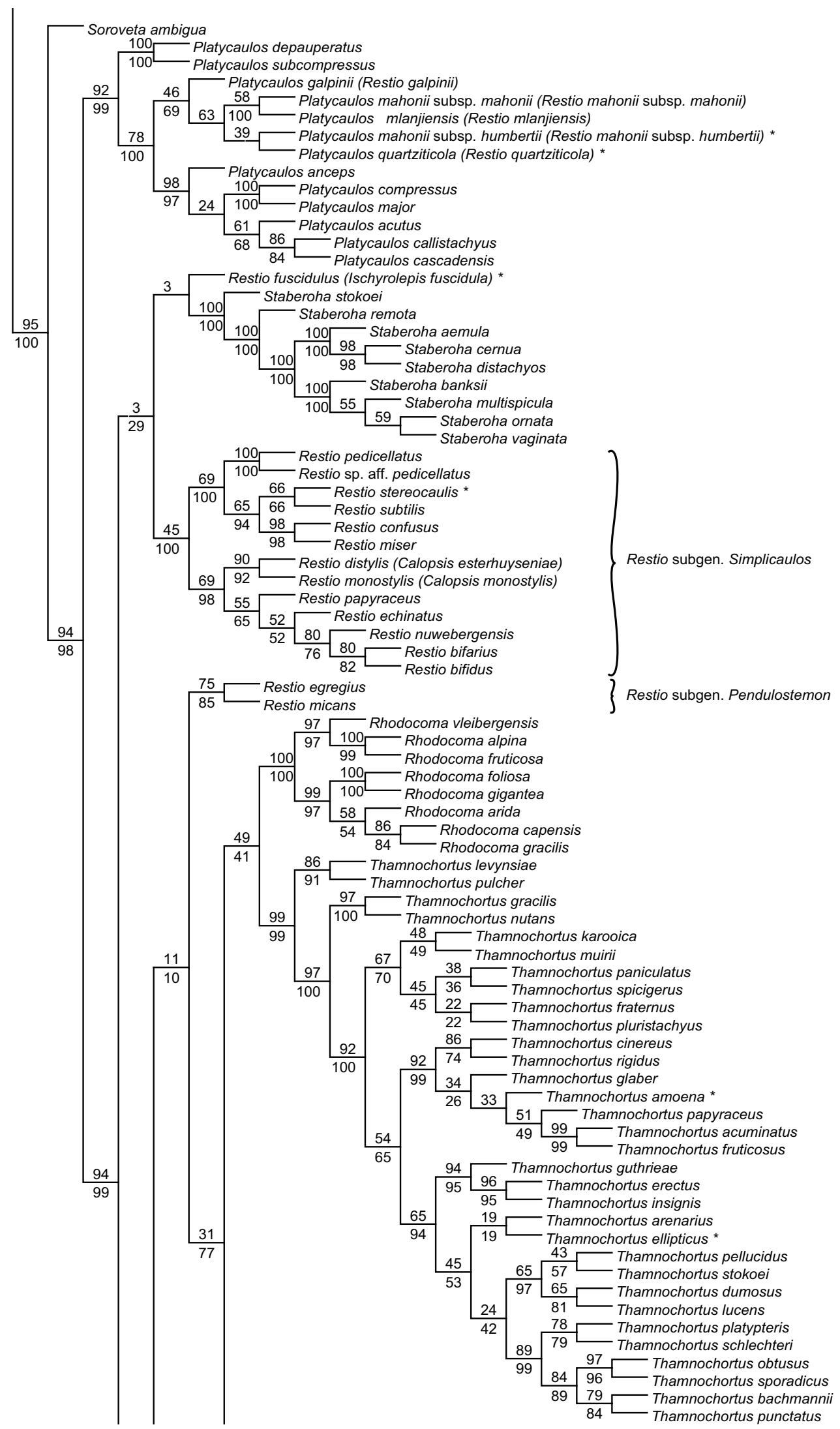

FIGURE 2.-Portion of strict consensus tree of total combined analysis of all species by Hardy et al. (2008) containing Soroveta, Platycaulos, Staberoha, Restio subgen. Simplicaulos, Restio subgen. Pendulostemon, Rhodocoma, and Thamnochortus. Names in parentheses are the now synonymous names of Linder (2001a) when different from the ones here proposed. A single species of Restio subgen. Ischyrolepis (Restio fuscidulus) that was missing many data (including all molecular data), was resolved in this tree as sister to Staberoha, albeit with $3 \%$ bootstrap support which we do not consider substantial enough to warrant disputing the monophyly of Restio subgen. Ischyrolepis or the genus Restio as circumscribed here. Bootstrap values above branches indicate support based on a 500-replicate bootstrap analysis that included 20 species for which DNA data were lacking (asterisked taxa). Bootstrap values below branches indicate support based on an analysis that excluded these morphology-only taxa. Where no value is given below a branch, it indicates that the clade did not appear in the analysis excluding morphology-only species. 
tile, dehiscent locules. Seed brown, black, white or tan, with brittle white ornamentation or rarely rugose. $\mathrm{Culm}$ anatomy: epidermal cells in 1 layer, lateral wall straight, unthickened; parenchymatous layer of 1-4 cells; central ground tissue without cavity; tannin absent or present in epidermis, sclerenchyma or central ground tissue; silica absent.

Etymology: Platycaulos (m.): platys (Greek), broad, flat; kaulos (Greek), stalk; referring to the compressed culms typical of this genus.

Notes: the genus was separated from Restio by Linder in 1984, based on a range of morphological, anatomical and palynological attributes. At the time, Linder did not realise that these features were also visible in the tropical species (now included below via new combinations), albeit in a less than obvious fashion. Fortunately, the taxon's namesake attribute, the more or less compressed culms, is also found in the tropical species, therefore the generic name remains appropriate. Almost all species are found in habitats with impeded drainage or summer rainfall.

2.1. Platycaulos depauperatus (Kunth) H.P.Linder in Bothalia 15: 436 (1985).

2.2. Platycaulos subcompressus (Pillans) H.P.Linder in Bothalia 15: 347 (1985).

\subsection{Platycaulosgalpinii (Pillans) H.P.Linder \& C.R} Hardy, comb. nov.

Restio galpinii Pillans in Transactions of the Royal Society of South Africa 30: 250 (1945). Type: Natal, Underberg, between Cathkin Peak and Giants Castle, Esterhuysen 8820 (BOL, lecto.! [Linder in Bothalia 15: 447 (1985)], K!, NBG!, NY).

2.4a.Platycaulos mahonii (N.E.Br.)H.P.Linder \& C.R. Hardy subsp. mahonii, comb. nov.

Hypolaena mahonii N.E.Br. in Flora of tropical Africa 8: 265 (1901). Restio mahonii (N.E.Br.) Pillans: 255 (1945). Type: Malawi, Southern Province, Mt Zomba, Mahon s.n. (K, holo.!; B!, BOL!).

2.4b. Platycaulos mahonii (N.E.Br.) H.P.Linder \& C.R.Hardy subsp. humbertii (Cherm.) H.P.Linder \& C.R. Hardy, comb. nov.

Restio madagascariensis Cherm. var. humbertii Cherm. in Archives de Botanique, Bulletin Mensuel, Caen 7: 85 (1930). R. mahonii (N.E.Br.) Linder subsp. humbertii (Cherm.) H.P.Linder: 103 (1986) Type: Madagascar, massif de l'Andohahelo, Humbert 6147 (P, holo.!; $\mathrm{B}$ !, K!, NY).

2.5. Platycaulos mlanjiensis (H.P.Linder) H.P.Linder \& C.R.Hardy, comb. nov.

Restio mlanjiensis H.P.Linder in Kew Bulletin 50: 623 (1995). Type: Malawi, Mt Mlanje, Sombani, Verboom, Pauw \& Hooks 1 (BOL, holo.!; K!, MAL!, MO!, NSW!, PRE!, S!, SRGH!, WAG!, Z!).

2.6. Platycaulos quartziticola (H.P.Linder) H.P. Linder \& C.R.Hardy, comb. nov.

Restio quartziticola H.P.Linder in Kew Bulletin 41:103 (1986). Type: Zimbabwe, Chimanimani Mts, Whellan 1252 (K, holo.!; BOL!, BR, LISC, SRGH!).

2.7. Platycaulos compressus (Rottb.) H.P.Linder in Bothalia 15: 436 (1985).

2.8. Platycaulos major (Mast.) H.P.Linder in Bothalia 15: 436 (1985).

2.9. Platycaulos anceps (Mast.) H.P.Linder in Bothalia 15: 436 (1985).

2.10. Platycaulos acutus Esterh. in Linder in Bothalia 15: 434 (1985).
2.11. Platycaulos cascadensis (Pillans) H.P.Linder in Bothalia 15: 436 (1985).

2.12. Platycaulos callistachyus (Kunth) H.P.Linder in Bothalia 15: 436 (1985).

\section{Staberoha-Elegia clade}

Although molecular support for this clade is poor (see also Hardy et al. 2008), this clade makes sense morphologically, based largely on its combination of glabrous, conduplicate tepals and, mostly, simple, unbranched culms. Interestingly, the species in the family with pendulous male spikelets (e.g. Staberoha, Thamnochortus, Rhodocoma, Restio subgen. Pendulostemon H.P.Linder \& C.R.Hardy subgen. nov.) all occur in this clade, suggesting that pendulous male spikelets are either plesiomorphic or have evolved repeatedly in parallel within the clade.

Within this clade, the association between Staberoha and Restio subgen. Simplicaulos H.P.Linder \& C.R.Hardy subgen. nov. (Figure 2) is weak, and an alternative position is for Simplicaulos to be sister to Elegia, and for Staberoha to occupy an isolated position (Hardy et al. 2008). The two taxa may be linked morphologically by their simple culms, but that could be plesiomorphic in the whole clade, with a reversal in Restio subgen. Pendulostemon. Many species in these two taxa also have large female bracts that completely obscure the female flowers.

Restio subgen. Pendulostemon, consisting of just two species, is both phylogenetically and morphologically isolated in the clade. In particular, the branching culms of this genus are unusual for the clade, although species with branching culms also occur occasionally in Elegia and Thamnochortus.

The Thamnochortus-Rhodocoma subclade was previously recognized by Linder (1984). The two genera share pendulous male spikelets (also present in Staberoha and Restio subgen. Pendulostemon), scattered cavities in the central ground tissue, and sheaths of which the upper half is more or less membranous and soon decays. The genera have very different gynoecia: in Rhodocoma the ovaries are dehiscent, and the diaspore is a seed, whereas in Thamnochortus the ovaries are unilocular and indehiscent, and the fruit a soft-walled nut, included in an often widely winged, persistent perianth.

The Elegia-Askidiosperma subclade also dates back to the morphological phylogeny of Linder (1984), and is recognized by the caducous, or when persistent, poorly structured sheaths, and the inflorescences with numerous partial panicles originating from several nodes along a central axis. Furthermore, the tepals are quite bony, with generally no differentiation between the lateral and odd tepals. The central ground tissue lacks a cavity. Elegia is distinguished from Askidiosperma by a double-layered culm epidermis, whereas Askidiosperma is diagnosed by the very long, membranous bracts, and its more welldefined spikelets.

3. Staberoha Kunth, Enumeratio plantarum 3: 442 (1841). Lectotype: Staberoha distachyos (Rottb.) Kunth.

Plants caespitose or clumped. Fertile culms unbranched, round; sheaths persistent, closely or rarely loosely convoluted, margins usually like rest of sheath, rarely nar- 
rowly or broadly membranous, but hyaline shoulders never developed. Male inflorescence paniculate with 1 to several \pm globose spikelets, pendulous on flattened, flexible pedicels, rarely racemose and erect (S. stokoei); bracts much taller than flowers and completely obscuring them; tepals papery, lateral tepals keeled; anthers usually included in flowers at anthesis. Female inflorescence racemose with 1-5 linear, oblong, elliptical or ovate, erect spikelets, each with 6-25 flowers and no sterile bracts; female bracts at least twice as long as and obscuring flowers, imbricate. Female flowers laterally compressed; tepals mostly chartaceous, glabrous, outer lateral tepals flattened, keeled or winged; staminodes sometimes present. Gynoecium with 1-3, white, flattened styles obscured behind bracts at anthesis; style bases usually free or rarely seated on a stylopodium; ovary unilocular, indehiscent. Fruit a soft-walled nut dispersed with persistent, often winged, perianth. Culm anatomy: epidermal cells in 1 layer, lateral wall usually straight and unthickened, rarely sinuose and thickened; parenchymatous layer of 1-4 cells; central ground tissue rarely solid, usually with scattered cavities or a single, central cavity; tannin usually absent, if present usually restricted to epidermis; silica absent.

Etymology: Staberoha (f.): named after H. Staberoh, a medical doctor, pharmacist and experimentalist.

Notes: a very distinctive genus, almost restricted to the Western Cape, where often several species are found co-occurring. The ball-like, pendulous male spikelets and the small female flowers obscured behind the large female bracts allow an easy recognition of the genus. All species are found on well-drained soils, both on deep sandy soils (such as Staberoha distachyos) and on rocky slopes $(S$. remota). S. stokoei is a remarkable exception to many of the morphological attributes (the male spikelets are erect, and almost identical to the female spikelets), and is a geographically restricted species in the Great Swartberg, where it occupies almost vertical rock ledges on the upper south-facing slopes. It is satisfying to see that it occupies a topological position sister to the rest of the genus, indicating that many of the distinctive attributes of the genus evolved after the origin of the genus. If subdivision of the genus is appropriate, then $S$. stokoei could be regarded as one division, and the rest of the genus the second.

The pollen of this genus is unusual, with a thickened annulus, very similar to the pollen typical of the Poaceae (Linder \& Ferguson 1985). Similar pollen is also found in Restio subgen. Ischyrolepis. In the morphological analysis by Linder (1984) this pollen played an important role in emphasizing the phylogenetically early branching position of Staberoha, but the molecular analysis indicates that this curious pollen type most likely evolved twice, independently, in the Restioneae.

3.1. Staberoha stokoei Pillans in Journal of South African Botany 18: 118 (1952).

3.2. Staberoha remota Pillans in Transactions of the Royal Society of South Africa 29: 351 (1942).

3.3. Staberoha aemula (Kunth) Pillans in Transactions of the Royal Society of South Africa 16: 386 (1928).

3.4. Staberoha cernua (L.f.) Dur. \& Schinz, Conspectus florae africae 5: 520 (1894).
3.5. Staberoha distachyos (Rottb.) Kunth, Enumeratio plantarum 3: 444 (1841).

3.6. Staberoha banksii Pillans in Transactions of the Royal Society of South Africa 16: 385 (1928).

3.7. Staberoha multispicula Pillans in Journal of South African Botany 18: 117 (1952).

3.8. Staberoha ornata Esterh. in Linder in Bothalia 15: 396 (1985).

3.9. Staberoha vaginata (Thunb.) Pillans in Transactions of the Royal Society of South Africa 16: 384 (1928).

4. Thamnochortus P.J.Bergius, Descriptiones plantarum ex Capite Bonae Spei 353 (1767). Type: Thamnochortus fruticosus P.J.Bergius.

Plants caespitose or with spreading underground rhizomes. Fertile culms round and, except in two species, simple; sheaths persistent, closely convoluted, upper half broadly chartaceous and soon becoming lacerated, hyaline shoulders absent. Male inflorescence paniculate from one or several nodes, with up to 100 spikelets; spathes persistent; spikelets generally lorate to oblong, pendulous on flexible pedicels; bract margins like body of bract, much taller than and obscuring papery male flowers; anthers included in flowers at anthesis. Female inflorescence racemose or somewhat paniculate, with 1100 erect, many-flowered, lorate to obtriangular spikelets; bracts taller than flowers with only stigmas visible at anthesis. Female flowers with glabrous and smooth tepals; outer lateral tepals strongly keeled or widely winged; staminodes usually absent. Gynoecium with solitary, white, plumose style; ovary unilocular, indehiscent. Diaspore an oblong to completely round, wind-dispersed structure; nut enclosed by persistent perianth. Culm anatomy: epidermal cells single-layered, lateral walls usually sinuose and thickened; parenchymatous layer of 1-4 cells; central ground tissue with scattered cavities; tannin present in epidermis, parenchyma, sclerenchyma or central ground tissue; silica mostly absent.

Etymology: Thamnochortus (m.): thamnos (Greek), bush, shrub; chortus (Greek), green herbage, grass, fodder.

Notes: mostly associated with more arid areas, especially in the northwestern Cape, along the coastal plains (Thamnochortus bachmannii), Nieuwoudtville (T. platypteris), but also typical of the wettest fynbos vegetation (T. cinereus). Also noted for the important thatching plants (T. insignis). The plants often form extensive stands, and can locally dominate the vegetation. Striking in some species are the widely winged, persistent perianths, making for efficient wind dispersal of the seed.

This genus is very clearly demarcated, and is very readily diagnosed by the slender, pendulous male spikelets, the closely convoluted sheaths with a decaying upper half, the many-flowered, erect female spikelets, and the single plumose style. The closest relative is Rhodocoma, with which it shares features of the culm anatomy and pollen structure, as well as the pendulous male spikelets. However, Thamnochortus has an indehiscent, unilocular ovary, whereas Rhodocoma has a dehiscent, three-locular ovary. In many ways this relationship is similar to that between Chondropetalum and Elegia s.str., but in the case of Thamnochortus there are no morphological intermediates and there is strong 
molecular evidence for the reciprocal monophyly of the two genera.

The biogeography and evolution in this genus was investigated by Linder \& Mann (1998). It is possible to assign the species to five main groups, not all of which are monophyletic (Figure 2).

a) Basal grade: includes the only two species with branching culms:

4.1. Thamnochortus levynsiae Pillans in Transactions of the Royal Society of South Africa 16: 364 (1928).

4.2. Thamnochortus pulcher Pillans in Transactions of the Royal Society of South Africa 29: 350 (1942).

4.3. Thamnochortus nutans (Thunb.) Pillans in Transactions of the Royal Society of South Africa 16: 365 (1928). 4.4. Thamnochortus gracilis Mast. in A.DC., Monographiae phanerogamarum 1: 327 (1878).

b) Limestone clade: all species associated with limestones or coastal dunes, except T. karooica:

4.5. Thamnochortus karooica H.P.Linder in South African Journal of Botany 56: 450 (1990).

4.6. Thamnochortus muirii Pillans in Transactions of the Royal Society of South Africa 16: 366 (1928).

4.7. Thamnochortus paniculatus Mast. in Botanische Jahrbücher 29, Beiblatt 66: 12 (1900b).

4.8. Thamnochortus spicigerus (Thunb.) Spreng., Systema vegetabilium 1: 187 (1824).

4.9. Thamnochortus fraternus Pillans in Transactions of the Royal Society of South Africa 16: 370 (1928).

4.10. Thamnochortus pluristachyus Mast. in Botanische Jahrbücher 29, Beiblatt 66: 12 (1900b).

c) Big bract group: species with large, often silvercoloured female bracts:

4.11. Thamnochortus cinereus H.P.Linder in Bothalia 15: 473 (1985).

4.12. Thamnochortus rigidus Esterh. in Linder in Bothalia 15: 477 (1985).

4.13. Thamnochortus glaber (Mast.) Pillans in Transactions of the Royal Society of South Africa 16: 363 (1928).

4.14. Thamnochortus papyraceus Pillans in Transactions of the Royal Society of South Africa 29: 350 (1942).

4.15. Thamnochortus amoena H.P.Linder in South African Journal of Botany 56: 451 (1990).

4.16. Thamnochortus acuminatus Pillans in Transactions of the Royal Society of South Africa 29: 349 (1942).

4.17. Thamnochortus fruticosus P.J.Bergius, Descriptiones plantarum ex Capite Bonae Spei 353 (1767).

d) Thatching reed group: plants up to $2 \mathrm{~m}$ tall:

4.18. Thamnochortus erectus (Thunb.) Mast. in Journal of the Linnean Society, Botany 14: 419 (1874).

4.19. Thamnochortus insignis Mast. in Gardeners' Chronicle, ser. 3, 25: 242 (1899).

e) Typical group: mostly plants $<1 \mathrm{~m}$ tall, diaspores often round (as broad as long):

4.20. Thamnochortus guthrieae Pillans in Transactions of the Royal Society of South Africa 16: 371 (1928).
4.21. Thamnochortus ellipticus Pillans in Transactions of the Royal Society of South Africa 16: 368 (1928). 4.22. Thamnochortus lucens (Poir.) H.P.Linder in Bothalia 15: 475 (1985).

4.23. Thamnochortus arenarius Esterh. in Linder in Bothalia 15: 472 (1985).

4.24. Thamnochortus sporadicus Pillans in Journal of South African Botany 18: 116 (1952).

4.25. Thamnochortus pellucidus Pillans in Journal of South African Botany 18: 113 (1952).

4.26. Thamnochortus obtusus Pillans in Journal of South African Botany 18: 112 (1952).

4.27. Thamnochortus stokoei Pillans in Transactions of the Royal Society of South Africa 16: 375 (1928).

4.28. Thamnochortus dumosus Mast. in Botanische Jahrbücher 29, Beiblatt 66: 11 (1900b).

4.29. Thamnochortus platypteris Kunth in Enumeratio plantarum 3: 429 (1841).

4.30. Thamnochortus schlechteri Pillans in Transactions of the Royal Society of South Africa 16: 372 (1928).

4.31. Thamnochortus bachmannii Mast. in Annalen des Kaiserlich-Königlichen Naturhistorischen Hofmuseums, Wien 15: 11 (1900a).

4.32. Thamnochortus punctatus Pillans in Transactions of the Royal Society of South Africa 16: 376 (1928).

5. Rhodocoma Nees in Lindl., A natural system of botany, edn 2: 450 (1836). Type: Rhodocoma capensis Nees ex Steud.

Plants caespitose or with straight rhizomes. Fertile culms round, unbranched or in $R$. capensis much branched with branches whorled at each node; sheaths persistent, upper half chartaceous and soon decaying, leaving a lacerated remnant; hyaline shoulders absent. Male inflorescence racemose from several nodes, each partial inflorescence with several to numerous pendulous spikelets on flexible pedicels; spikelets \pm elliptical; bracts without distinct membranous upper margin; anthers included in flowers at anthesis. Female inflorescence similar to male, but partial inflorescences stiffly erect with few to several spikelets; spathes sometimes prominent and membranous or chartaceous; spikelets elliptical to ovate, with 1-5 flowers; bracts shorter than flowers. Female flowers not laterally compressed; tepals bony, glabrous and smooth; staminodes present. Gynoecium with 3, white to red, feathery styles free to base; ovary 3-locular, dehiscent or rarely falling with seed. Seed brown, grey or tan, colliculate or rugose. Culm anatomy: epidermal cells 1-layered, lateral walls straight and unthickened or sinuose and thickened; parenchyma of 1-4 rows of cells; central ground tissue with scattered cavities; tannin present in epidermis, parenchyma, sclerenchyma and central ground tissue; silica usually absent, or when present, in parenchyma.

Etymology: Rhodocoma (f.): rhodon (Greek), rosy; kome (Greek), hair of the head; presumably referring to the strikingly red or rosy styles in the type species, $R$. capensis.

Notes: most of the species are found in the southern Cape, where a clear pattern of ecological and geographical replacement is evident. Rhodocoma fruticosa is widespread from the Cape to the Drakensberg, and is very common over large areas along the eastern margins of the fynbos. 
Superficially the species are similar to Thamnochortus, especially because of the pendulous male spikelets and the similar culm and sheath construction. However, they can be separated by the dehiscent female ovaries, by the short bracts in the females, and less confidently by the shorter and more elliptical spikelets.

The evolution in this genus has been investigated twice, first by Linder \& Vlok (1991), then by Hardy \& Linder (2007).

\subsection{Rhodocoma foliosa (N.E.Br.) H.P.Linder \&} C.R.Hardy, comb. nov.

Restio foliosus N.E.Br. in Flora capensis 7: 753 (1900). Type: Garcia's Pass, Galpin 4783 (K, lecto.! [Linder in Bothalia 15: 478 (1985)]; B!, BOL!, K!),

5.2. Rhodocoma gigantea (Kunth) H.P.Linder in Bothalia 15: 479 (1985).

5.3. Rhodocoma capensis Nees ex Steud., Synopsis plantarum glumacearum 2: 249 (1855).

5.4. Rhodocoma gracilis H.P.Linder \& Vlok in Plant Systematics and Evolution 175: 156 (1991).

5.5. Rhodocoma arida H.P.Linder \& Vlok in Plant Systematics and Evolution 175: 158 (1991).

5.6. Rhodocoma vleibergensis H.P.Linder, sp. nov., $R$. aridae affinis, sed caespitibus pauciculmis, spiculis femineis longioribus (5-7 mm longis), stomatibus superficiebus notabilis.

TYPE.-Western Cape, 3319 (Worcester): Ceres, Baviaanshoek, Vleiberg, (-BA), 14-10-1994, H.P.Linder 5882 (BOL, holo.; K, Z).

Plants tufted with few 1.0-1.5 m tall culms and with spreading rhizomes. Fertile culms unbranched, smooth, olivaceous, apical diam. 1.5-2.5 mm; sheaths closely convoluted, 40-60 mm long, apical margins broadly chartaceous and soon decaying, hyaline shoulders absent, apically acute; mucro penicillate, straight and erect, 4-10 mm long. Male inflorescence with up to 500 spikelets, paniculate, 80-300 × 30-50 mm; spathes persistent, chartaceous, upper margins lacerated and largely decayed at anthesis, shorter than spikelets; spikelets pendulous on flexible pedicels longer than spikelets, elliptical, rounded, 4.5$6.5 \mathrm{~mm}$ long, 5-7-flowered; bracts shorter than to as tall as flowers, 1.5-2.5 mm long, oblong or ovate, rounded or obtuse, chartaceous. Male flower 2.0-2.5 mm long; tepals all same size, cartilaginous, glabrous, outer lateral tepals conduplicate; anthers $1.2-1.4 \mathrm{~mm}$ long, included in flowers, pistillode present. Female inflorescence with up to 500 spikelets, paniculate, sparsely branching, stiffly erect, 80 $200 \times 10-30 \mathrm{~mm}$; spathes persistent, chartaceous or membranous, longer than spikelets but not obscuring them; spikelets 1-flowered, with 3-6 sterile bracts shorter than flowers, 2-3 mm long, ovate, rounded or obtuse or acute, chartaceous. Female flower 4.5-6.0 mm long; tepals bony, glabrous and smooth, midrib flush with tepal body, apices acute, inner and outer whorls of same length; staminodes present. Gynoecium: styles feathery, white, 3, free to base; ovary with 3 dehiscent locules. Culm anatomy: epidermal cells single-layered, lateral wall sinuose, thickened, outer wall thickened, colliculate; glabrous, $1 / w$ ratio $6: 4$, all the same length; stomatal apparatus superficial, guard cells seated on top of support cells; chlorenchyma of 2 layers of cells, $1 / \mathrm{w}$ ratio $12: 8$, inner and outer layers somewhat dissimilar; protective cells reaching to base of chlorenchyma layer; parenchymatous layer of 2 or 3 cells, cells smaller than epidermal cells; sclerenchyma ring of 9-13 layers, without protrusions, cell walls thick; central ground tissue with scattered cavities; tannin present in epidermis, sclerenchyma or central ground tissue; silica sand absent. Flowering time: September, seed release in November.

Etymology: Vleiberg, a little known peak in the Swartruggens, from which this new species was first recorded.

Distribution and ecology: endemic to the western margins of the Tanqua Karoo, from the Bonteberg at Touws River, northwards via Baviaansberg, Vleiberg to the Bokkeveld Sneeukop. The altitude is from 1 000-1 $600 \mathrm{~m}$, the habitat restricted to sandstone- or quartzite-derived soils, where populations are found in welldrained habitats on rocky slopes. The plants are killed by fire, and populations are re-established from seed.

Discussion: this species is morphologically very similar to Rhodocoma arida, but with a different 'gestalt', the plants being smaller, tattier looking, and spreading with a more developed rhizome. The spikelets are generally larger. This applies particularly to the female spikelets. Furthermore, there is a geographical separation, with $R$. vleibergensis found north of the Laingsburg Witteberg, and $R$. arida east of this line. This also determines the proportion of summer rain in the area, with $R$. arida receiving a substantial proportion of its rain in summer, whereas $R$. vleibergensis receives almost no summer rain. Despite the morphological similarity to $R$. arida, the phylogeny of Hardy \& Linder (2007) indicates that the species is more closely related to the $R$. alpina-R. fruticosa subclade.

\section{Additional collections}

WESTERN CAPE.-3319 (Worcester): Ceres, Baviaanshoek, Watervalsberg, between top of track and trig beacon, common on stony soils, (-BA), 14-10-1994, H.P.Linder 5854 (Z, K); Bonteberg, Abrahamshoek, summit ridge on well-drained soils, (-BB), 25-10-2000, H.P.Linder $7103(\mathrm{Z})$

5.7. Rhodocoma fruticosa (Thunb.) H.P.Linder in Bothalia 15: 478 (1985).

5.8. Rhodocoma alpina H.P.Linder \& Vlok in Plant Systematics and Evolution 175: 156 (1991).

6. Elegia $L$. , Mantissa plantarum altera 162 (1771). Type: Elegia juncea L.

Chondropetalum Rottb.: 11 (1772). Type: Chondropetalum deustum Rottb. [= Elegia deusta (Rottb.) Kunth], lecto. [Linder 1984].

Dovea Kunth: 457 (1841). Type: Dovea macrocarpa Kunth [= Elegia macrocarpa (Kunth) Moline \& H.P. Linder].

Lamprocaulis Mast. in A.DC.: 349 (1878). Type: Lamprocaulis grandis (Kunth) Mast. [= Elegia grandis Kunth].

Plants tufted, clumped or mat-forming, often with well-developed, spreading rhizomes. Fertile culms mostly unbranched, in some species branched, and in two species branches whorled at each node, mostly round, sometimes \pm compressed; sheaths sometimes persistent, but more commonly caducous with distinct abscission line, 
when present, most commonly loosely convoluted and same texture over whole structure, rarely upper margins membranous or otherwise different from rest of organ. Male inflorescence of several clusters of partial, paniculate inflorescences, each with several to very numerous flowers only poorly organized into spikelets; young partial inflorescences generally hidden behind large spathes, which drop before anthesis; large spathe-like spathellae occasionally present; male bracts usually shorter than perianth, but in appearance similar to tepals. Male flowers with undifferentiated, glabrous tepals; anthers included in flowers at anthesis. Female inflorescence structurally similar to male inflorescences; each partial inflorescence with 1-many flowers, these poorly organized into spikelets; spathes large, usually persistent, often completely obscuring flowers at anthesis; spikelets often clustered in paniculate partial inflorescences, making them difficult to delimit; bracts mostly shorter than flowers with no differentiation between body and margin, rarely acuminate and/or lacerated on margins. Female flowers with undifferentiated, glabrous tepals; staminodes usually present. Gynoecium with 2 or 3 mostly feathery styles free to base or more rarely seated on a stylopodium; ovary with 3 usually dehiscent or 1 indehiscent locule. Nuts generally triangular, often black, without elaiosomes, perianth sometimes persistent on nuts but never winged; seeds from dehiscent ovaries often brown and smooth. Culm anatomy: epidermal cells almost always in 2 layers, lateral wall straight, unthickened; parenchymatous layer of 1-6 cells; central ground tissue solid or with scattered cavities, rarely with a single, central cavity; tannin usually in epidermis and central ground tissue, rarely in parenchyma or sclerenchyma; silica absent.

Etymology: Elegia (f.), from the Greek elegos, meaning weeping or lament, and this was then used by Plinius in the Latinized form of Elegia to refer to a kind of reed.

Notes: this genus contains a remarkably wide range of variation in morphology, previously recognized as four genera. However, this variation does not readily group into reciprocally monophyletic groups, and consequently the whole group is best treated as one large genus, as suggested by Moline \& Linder (2005). This larger clade is readily diagnosed by anatomical attributes (epidermis in two layers: Figure 1). The morphological attributes (caducous sheaths; paniculate inflorescences) have numerous exceptions, which makes them more difficult to use.

The genus contains several well-known species, such as Elegia tectorum, widely cultivated, previously widely used as a thatching reed; E. capensis, widely cultivated, dominant in many areas in regions with some groundwater, where the stoloniferous growth allows the species to take over the vegetation; E. filacea, which has an enormous ecological range, and is found in almost all vegetation types.

The species are organized into four clades (Figure 3).

a) Elegia mucronata clade, without obvious characters:

6.1. Elegia cuspidata Mast. in Journal of the Linnean Society, Botany 10: 240 (1868).

6.2. Elegia mucronata (Nees) Kunth, Enumeratio plantarum 3: 475 (1841). b) Chondropetalum clade: includes most species previously included in Chondropetalum. Morphologically this clade is defined by the dehiscent ovaries. However, it also includes Elegia verreauxii, which has an indehiscent ovary:

6.3. Elegia nuda (Rottb.) Kunth, Enumeratio plantarum 3: 462 (1841).

6.4. Elegia tectorum (L.f.) Moline \& H.P.Linder in Systematic Botany 30: 772 (2005).

6.5. Elegia elephantina H.P.Linder, sp. nov., a $E$. tectoro caespitibus elatioribus $(1.0-2.5 \mathrm{~m})$, culmis validioribus $(4-6 \mathrm{~mm})$, spiculis maribus maioribus (3.0-3.5 $\mathrm{mm}$ diametro), tepalis femineis exterioribus interiores aequantibus recedit.

TYPE.-Western Cape, 3318 (Cape Town): between Hopefield and Koperfontein, $33^{\circ} 05^{\prime} 31^{\prime \prime} \mathrm{S}, 18^{\circ} 34^{\prime} 36^{\prime \prime E}$, plants up to $2 \mathrm{~m}$ tall, forming small populations in hollows among the dunes, (-AB), 22-08-2000, H.P.Linder 7072 (Z, holo.).

Evergreen, tufted plants, 1.0-2.5 m tall. Rhizome spreading, unbranched or sparsely branched, culms evenly spaced. Fertile culms unbranched, round, smooth, olivaceous, 4-6 mm diam. at base, 1.4-2.5 mm diam. at apex; sheaths caducous, with an abscission line present, loosely convoluted, 30-60 mm long, margins entire, reddish to dark brown with fine tan speckles and tan margins, slightly glossy; sheath mucro penicillate, straight and erect, 6-10 mm long. Male inflorescence with more than 100 spikelets, paniculate, $80-500 \times 20-30 \mathrm{~mm}$; spathes caducous, taller than spikelets, cartilaginous; spikelets erect on short stiff pedicels, subglobose, $3.0-3.5 \mathrm{~mm}$ in diam., 3- or 4-flowered; bracts shorter than flowers, ovate, 1.2-1.7 mm long, acute, margins entire, chartaceous or cartilaginous, bract awn minute or absent. Male flower 2.3-2.9 mm long, glabrous; tepals chartaceous or cartilaginous, inner tepals longer than outer tepals, outer lateral tepals conduplicate; anthers included in flowers. Female inflorescence with more than 50 spikelets, interrupted, 80-400 × 15-20 mm; spathes longer than spikelets, caducous, bony; spikelets subglobose, 3.2-4.2 mm long, 4- or 5-flowered; bracts all fertile, shorter than flowers, erect, 1.5-2.0 mm long, orbicular (at times wider than tall), rounded or obtuse, cartilaginous (with a sturdy midrib), apical margin like rest of bract, same as body of bract, awn minute or absent. Female flowers 2.2-2.8 mm long, tepals bony, glabrous and smooth, midrib raised, margins entire, apices acute, inner and outer whorls equally long; outer lateral tepals conduplicate, odd outer tepal elliptical, inner tepals ovate, 1.8-2.3 mm long; staminodes present. Gynoecium with 3 feathery styles, bases free; 3-locular, dehiscent ovary. Seed $0.6-0.8 \times 0.3-0.5 \mathrm{~mm}$, shape in side view elliptical, shape round in diam. and rectangular in cross section, brown. Flowering time: July.

Distribution and ecology: endemic to the west coast of South Africa, from Blouberg to Elands Bay. Local in damp hollows and seepages on well-leached sand below $200 \mathrm{~m}$.

Etymology: this species is known as olifantsriet on the west coast. Unfortunately, this name appears to be applied to any very large member of the Restionaceae, thus is not very useful. The name is derived from the Latin for elephant: elephas. 


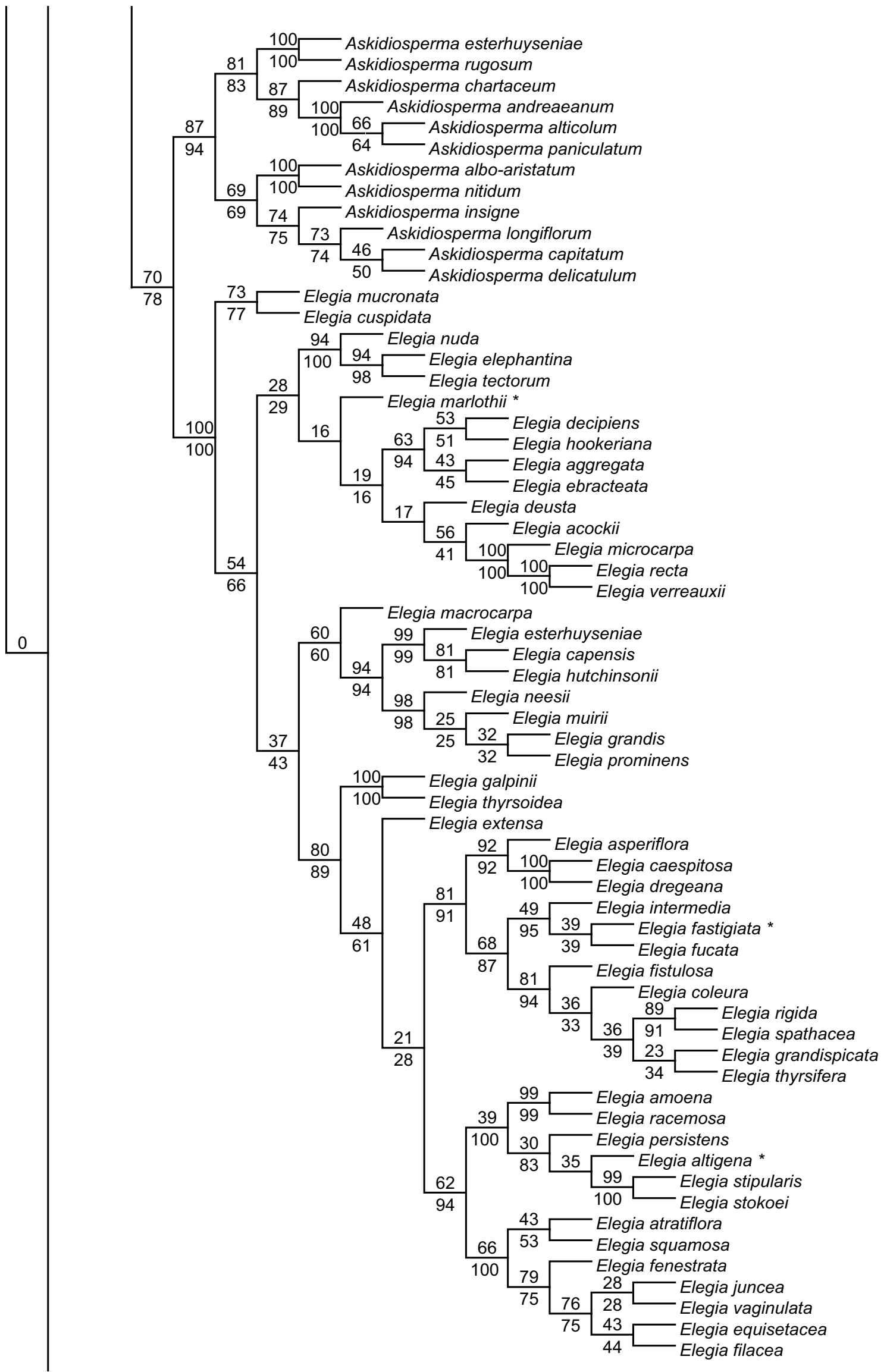

FIGURE 3.-Portion of strict consensus tree of total combined analysis of Hardy et al. (2008) containing Askidiosperma and Elegia sensu Moline $\&$ Linder (2005). Bootstrap values above the branches indicate support based on a 500-replicate bootstrap analysis that included 20 species for which DNA data were lacking (asterisked taxa). Bootstrap values below branches indicate support based upon a 500-replicate analysis that included only taxa for which both DNA data and morphology data were available. Where no value is given below a branch, it indicates that the clade did not appear in the analysis excluding morphology-only species. 
Discussion: this species is very close to Elegia tector$u m$, from which it primarily differs in being bigger in all dimensions. Furthermore, the inner and outer whorls of the female tepals are the same length, whereas in $E$. tectorum the inner tepals are longer than the outer. Both species co-occur on the west coast at Blouberg, and no intermediate plants have been seen.

6.6. Elegia marlothii (Pillans) Moline \& H.P.Linder in Systematic Botany 30: 772 (2005).

6.7. Elegia hookeriana (Mast.) Moline \& H.P.Linder in Systematic Botany 30: 772 (2005).

6.8. Elegia decipiens (Esterh.) Moline \& H.P.Linder in Systematic Botany 30: 771 (2005).

6.9. Elegia ebracteata (Kunth) Moline \& H.P.Linder in Systematic Botany 30: 771 (2005).

6.10. Elegia aggregata (Mast.) Moline \& H.P.Linder in Systematic Botany 30: 771 (2005).

6.11. Elegia deusta (Rottb.) Kunth, Enumeratio plantarum 3: 460 (1841).

6.12. Elegia acockii (Pillans) Moline \& H.P.Linder in Systematic Botany 30: 771 (2005).

6.13. Elegia microcarpa (Kunth) Moline \& H.P.Linder in Systematic Botany 30: 772 (2005).

6.14. Elegia recta (Mast.) Moline \& H.P.Linder in Systematic Botany 30: 772 (2005).

6.15. Elegia verreauxii Mast. in Journal of the Linnean Society, Botany 21: 589 (1885).

c) Lamprocaulis clade: includes most species with branching culms, and which have, except for Elegia macrocarpa, indehiscent nuts. In several species the sheaths are persistent:

6.16. Elegia macrocarpa (Kunth) Moline \& H.P.Linder in Systematic Botany 30: 772 (2005).

6.17. Elegia capensis (Burm.f.) Schelpe in Journal of South African Botany 33: 156 (1967).

6.18. Elegia hutchinsonii Pillans in Transactions of the Royal Society of South Africa 29: 344 (1942).

6.19. Elegia esterhuyseniae Pillans in Transactions of the Royal Society of South Africa 30: 259 (1945).

6.20. Elegia neesii Mast. in Journal of the Linnean Society, Botany 10: 246 (1868).

6.21. Elegia muirii Pillans in Transactions of the Royal Society of South Africa 16: 319 (1928).

6.22. Elegia grandis (Nees) Kunth, Enumeratio plantarum 3: 475 (1841).

6.23. Elegia prominens Pillans in Transactions of the Royal Society of South Africa 16: 320 (1928).

d) Elegia clade: includes almost all species of the previous genus Elegia, characterized by the indehiscent ovaries and usually unbranched culms:

6.24. Elegia galpinii N.E.Br. in Flora capensis 7: 754 (1900).

6.25. Elegia thyrsoidea (Mast.) Pillans in Annals of the Bolus Herbarium 3,3: 146 (1922).

6.26. Elegia extensa Pillans in Transactions of the Royal Society of South Africa 29: 343 (1942).

6.27. Elegia asperiflora (Nees) Kunth, Enumeratio plantarum 3: 474 (1841).

6.28. Elegia caespitosa Esterh. in Linder in Bothalia 15: 421 (1985).

6.29. Elegia dregeana Kunth, Enumeratio plantarum 3: 469 (1841).
6.30. Elegia intermedia (Steud.) Pillans in Transactions of the Royal Society of South Africa 16: 332 (1928).

6.31. Elegia fastigiata Mast. in Botanische Jahrbücher 29, Beiblatt 66: 7 (1900b).

6.32. Elegia fucata Esterh. in Linder in Bothalia 15: 423 (1985).

6.33. Elegia fistulosa Kunth, Enumeratio plantarum 3: 467 (1841).

6.34. Elegia coleura Nees ex Mast. in A.DC., Monographiae phanerogamarum 1: 358 (1878).

6.35. Elegia rigida Mast. in Journal of the Linnean Society, Botany 21: 587 (1885).

6.36. Elegia spathacea Mast. in Journal of the Linnean Society, Botany 21: 588 (1885).

6.37. Elegia grandispicata H.P.Linder in Bothalia 15: 424 (1985).

6.38. Elegia thyrsifera (Rottb.) Pers., Synopsis plantarum 2: 607 (1807).

6.39. Elegia fenestrata Pillans in Transactions of the Royal Society of South Africa 16: 338 (1928).

6.40. Elegia persistens Mast. in Botanische Jahrbücher 29 Beiblatt, 66: 8 (1900b).

6.41. Elegia racemosa (Poir.) Pers., Synopsis plantarum 2: 607 (1807).

6.42. Elegia amoena Pillans in Transactions of the Royal Society of South Africa 30: 258 (1945).

6.43. Elegia altigena Pillans in Transactions of the Royal Society of South Africa 30: 257 (1945).

6.44. Elegia equisetacea Mast. in Journal of the Linnean Society, Botany 21: 583 (1885).

6.45. Elegia filacea Mast. in Journal of the Linnean Society, Botany 21: 589 (1885).

6.46. Elegia atratiflora Esterh. in Linder in Bothalia 15: 420 (1985)

6.47. Elegia squamosa Mast. in Journal of the Linnean Society, Botany 10: 244 (1868).

6.48. Elegia stipularis Mast. in Journal of the Linnean Society, Botany 21: 587 (1885).

6.49. Elegia stokoei Pillans in Transactions of the Royal Society of South Africa 29: 345 (1942).

6.50. Elegia juncea $L$., Mantissa plantarum altera 297 (1771).

6.51. Elegia vaginulata Mast. in Journal of the Linnean Society, Botany 21: 586 (1885).

7. Askidiosperma Steud., Synopsis plantarum glumacearum 2: 257 (1855). Type: Askidiosperma capitatum Steud.

Plants caespitose. Fertile culms unbranched, round; sheaths dropping off, with an abscission line present, loosely convoluted or flat and standing free from culm, margins coriaceous, like rest of body, hyaline shoulders absent. Male inflorescence with 1 to several partial inflorescences subtended by large spathes; each partial inflorescence with 1 to several, many-flowered spikelets; bracts much taller than flowers, papery or membranous, margins entire or lacerated. Male flowers not laterally compressed; tepals glabrous, inner and outer often of different lengths; anthers included in flowers at anthesis. Female inflorescence, spikelets and flowers similar to male. Female flowers with staminodes. Gynoecium: styles 2 or 3, white, feathery, free to base; ovary 1-3-locular, dehiscent or sometimes dropping with seed. Seed silvery or more commonly brown and smooth. Culm 
anatomy: epidermis with a single layer of cells, lateral walls straight, unthickened; parenchyma of 1-3 layers of cells; central ground tissue solid, rarely with a single, central cavity; tannin usually absent, when present in epidermis, sclerenchyma or (rarely) in central ground tissue; silica usually absent, when present, in parenchyma or sclerenchyma.

Etymology: Askidiosperma (n.): from Greek askion or askidion, which is the diminutive of askos, which is a bag, sac, wine skin or hide; and sperma (n., Greek), which is a seed. The connection to the genus is unclear.

Notes: this genus shares with Elegia the caducous sheaths, and the tepals which are all the same (outer lateral tepals are not flattened and keeled). The species had been included in Chondropetalum by Pillans (1928), but were again separated by Linder (1984), as they differ from Elegia by the culms with simple (not doubled-layered) epidermis, and by the floral bracts which are hyaline-membranous and much taller than the flowers, as well as by the phytochemical composition (Harborne et al. 1985).

The species are mostly found in the western mountains, rather rarely in the southern mountains of the Western Cape, and are absent from the coastal flats and plains. Species range from seepages over bedrock (Askidiosperma insigne) to alluvial soils along streams and on well-drained rocky slopes.

7.1. Askidiosperma chartaceum (Pillans) H.P.Linder in Bothalia 15: 431 (1985).

7.2. Askidiosperma andreaeanum (Pillans) H.P.Linder in Bothalia 15: 431 (1985).

7.3. Askidiosperma alticolum (Esterh.) H.P.Linder in Nordic Journal of Botany 21: 198 (2001b).

7.4. Askidiosperma paniculatum (Mast.) H.P.Linder in Bothalia 15: 432 (1985).

7.5. Askidiosperma esterhuyseniae (Pillans) H.P.Linder in Bothalia 15: 432 (1985).

7.6. Askidiosperma rugosum Esterh. in Linder in Bothalia 15: 432 (1985).

7.7. Askidiosperma albo-aristatum (Pillans) H.P.Linder in Bothalia 15: 431 (1985).

7.8. Askidiosperma nitidum (Mast.) H.P.Linder in Bothalia 15: 432 (1985).

7.9. Askidiosperma insigne (Pillans) H.P.Linder in Bothalia 15: 432 (1985).

7.10. Askidiosperma longiflorum (Pillans) H.P.Linder in Bothalia 15: 432 (1985).

7.11. Askidiosperma capitatum Steud., Synopsis plantarum glumacearum. 2: 257 (1855).

7.12. Askidiosperma delicatulum H.P.Linder in Nordic Journal of Botany 21: 196 (2001b).

\section{Restio clade}

This large clade is readily defined by the laterally compressed female flowers, where the keels of the outer lateral tepals are more or less villous. In most species the culms are branching. This clade largely includes most of the segregates of the genus Restio sensu Linder (1984) and Calopsis sensu Linder (1984), as well as Ischyrolepis. Several strongly supported subclades are recognized: Craspedolepis, Calopsis s.str., Restio s.str.,
Locapsis and Ischyrolepis which are characterized by different apomorphies and apomorphic tendencies:

Craspedolepis: diagnosed by the bracts with hollow (deeply concave) cells along the upper margin (honeycomb cells), and the plants and spikelets tend to be robust, the ovaries mostly dehiscent, with two locules. In many species the spikelets are relatively massive.

Calopsis: highly paniculate inflorescences with very many small spikelets; culms mostly angular or even square.

Restio: sheaths mostly with large membranous lobes flanking the mucro; the plants and spikelets tend to be small, the ovary mostly unilocular and often indehiscent.

Locapsis: sheaths mostly spreading and without a differentiated apical margin; perianth papery, rounded; diaspore a nut.

Ischyrolepis: ovaries with two styles which are basally fused, this fused portion persisting as a peg on the dehisced ovary.

Varirestio and Eremorestio, however, lack characters, and are recognized in order to retain monophyly.

Morphologically, Eremorestio would fit with Locapsis, while Varirestio could be polymorphic. It remains possible that the apparent monophyly of these two segregates is an artifact of ancient hybridization, and that the plastid phylogeny is not tracking the species phylogeny.

However, the phylogenetic structure within the clade is unclear. There is little molecular support for the groupings, and we cannot postulate good morphological characters for the various molecular clades.

Also included in this clade are Pendulostemon and Simplicaulos. The balance of the evidence places these two segregates into the Staberoha-Elegia clade, but taxonomically they are better kept in the large Restio s.lat.

8. Restio Rottb., Descriptiones plantarum rariorum 9 (1772). Type: Restio triticeus Rottb. (lecto. McVaugh 1968).

Calopsis Beauv. ex Desv.: 44, t. 3 (1828). Type: Calopsis paniculata (Rottb.) Desv. (= Restio paniculatus Rottb.).

Ischyrolepis Steud.: 249 (1855). Type: Ischyrolepis subverticellatus Steud. (= Restio subverticellatus (Steud.) Mast.).

Craspedolepis Steud.: 264 (1855). Type: Craspedolepis verreauxii Steud. (= Restio filiformis Poir.).

Plants caespitose, clumped, tangled or mat-forming. Fertile culms simple or branching, round, or rarely square or compressed; sheaths persistent, closely or loosely convoluted, usually with a narrow membranous margin, often with tall, acute membranous lobes flanking mucro. Male and female inflorescences mostly very similar; mostly paniculate, more rarely racemose, with 1 to numerous spikelets; spathes usually persistent; 
bracts usually coriaceous, varying from shorter to taller than flowers; anthers exserted from flowers at anthesis. Female inflorescence occasionally with fewer spikelets than males; spikelets with up to 30 laterally compressed flowers; tepals chartaceous or cartilaginous, glabrous or sparsely (rarely densely) villous on keels of lateral sepals; staminodes present. Gynoecium with 1, 2 or 3 feathery styles free to base, fused into a basal peg, or rarely seated on a stylopodium; ovary 1-, 2- or 3-locular, either dehiscent or indehiscent. Diaspore either a seed or a soft-walled nut; seed variously coloured, usually smooth, occasionally colliculate; nut dropped with a persistent papery perianth that is sometimes winged. Culm anatomy: epidermal cells 1-layered, lateral walls straight and unthickened or sinuose and thickened; parenchymatous layer of up to 6 cells; central ground tissue either with no cavity, a single central cavity, or with scattered cavities; tannin rarely absent, when present then in the epidermis, sclerenchyma, or central ground tissue; silica either absent, or when present, in chlorenchyma or parenchyma.

Etymology: Restio (m., Latin), a ropemaker; it is unclear why Linnaeus referred to restios as such, since they are not to our knowledge useful for the making of ropes, due to the brittle nodes.

The extensive variation in the genus is best expressed in the eight subgenera recognized.

8.1. Restio subgen. Simplicaulos H.P.Linder \& C.R.Hardy, subgen. nov., primo adspectu Restioni, Craspedolepi, Calopsi, Locapsi, Varirestioni et Eremorestioni culmis rotundis, vaginis persistentibus, spiculis maribus erectis, staminodiis praesentibus, stylis libris maxime simile, sed a speciebus olim ad subgenera Calopsem et Restionem ascriptis culmis simplicibus et inflorescentiis maribus et femineis valde similibus differt.

\section{TYPE.—Restio bifidus Thunb.}

Plants usually tufted. Fertile culms mostly unbranched or rarely sparsely branched, round or very rarely compressed (Restio subtilis); sheaths persistent, closely or loosely convoluted or rarely flat and standing free from culm ( $R$. papyraceus); apical sheath margins narrowly or broadly membranous; hyaline shoulders absent or variously developed. Male inflorescence racemose, with 1-20 spikelets, paniculate with pendulous spikelets only in $R$. bifarius; spathes persistent; bracts with upper margin like body of bract, sometimes with hollow cells, obtuse to acuminate and recurved; anthers usually exserted from flowers at anthesis. Female inflorescence always racemose with 1-5 variously shaped, 1-40-flowered spikelets; bracts shorter to much longer than flowers, apical margin like rest of bract, membranous or with honeycombed cells, imbricate and obscuring spikelet axis. Flowers with outer lateral tepals usually conduplicate, but in three species, undifferentiated; all tepals cartilaginous, glabrous or keels of lateral sepals villous; staminodes present. Gynoecium with 1, 2 or 3 white, feathery, free styles; ovary with 1-3 dehiscent or rarely indehiscent locules. Fruit: in species with indehiscent ovaries, perianth winged, persistent around ovary, in species with dehiscent ovaries, seed silvery, brown or grey; surface pitted, colliculate or striate. Culm anatomy: epi- dermal cells in 1 layer, lateral wall straight, unthickened or rarely sinuose and thickened; parenchymatous layer of 1-3 cells; central ground tissue solid or rarely with scattered cavities or with single, central cavity; tannin absent or present in epidermis, sclerenchyma or central ground tissue; silica absent.

Etymology: Simplicaulos (m.): simplex (Latin), simple, unbranched; caulos (Greek), stem; referring to the usually unbranched culms in this subgenus.

Notes: many species in this subgenus are associated with impeded drainage, and Restio miser and R. confusus are often dominants in convex-domed seepages on shale bands and on sandstone. Restio bifidus is typical of shallow seepages, and can be dominant over much of the upper plateau of Table Mountain. However, many of the other species are found in well-drained habitats.

There are very distinct morphological groups in this subgenus. The first group has large, almost flat, bracts (Restio bifarius, $R$. bifidus, $R$. nuwebergensis and $R$. papyraceus), that are quite similar to the female spikelets of the possible sister clade Staberoha. The second group has small button-like spikelets, borne on fine-stemmed tussocky plants, often with only one spikelet per culm, and round female flowers in which the lateral tepals are not conduplicate ( $R$. subtilis, $R$. confusus, $R$. miser). The third group has thick spindle-shaped spikelets, and nutlets with a persistent perianth forming a wing ( $R$. monostylis, $R$. esterhuyseniae). Finally, $R$. echinatus and $R$. pedicellatus have acuminate bracts.

This subgenus lacks any striking synapomorphies. However, optimization on the phylogeny shows that the subgenus ancestrally had simple culms, and that branched culms evolved only in the Restio bifarius group. Even in this group, branching is often absent, and when present, is sparse. The unbranched culms are shared with its possibly nearest relatives, Elegia and Staberoha, but differentiate the subgenus from the rest of the genus Restio. Although it is easy to differentiate subgen. Simplicaulos from its putative phylogenetic relatives Staberoha or Elegia by the persistent sheaths, by staminodes still present in the female spikelets, the (mostly) erect male spikelets and the male flowers aggregated into clear spikelets, these are all plesiomorphic features. It is remarkable how variable the subgenus is regarding previously used generic characters, such as the number of locules and styles and the type of diaspore (nut or seed). Not surprisingly, subgen. Simplicaulos contains species previously placed in Restio sensu Linder 1985 and Calopsis sensu Linder 1985.

Although the clade is strongly supported, its position within the Restioneae is not. The plastid data suggests (weakly) a phylogenetic relationship to Staberoha or Elegia, but the possibility that it is related to Restio s.lat. cannot be rejected, even by plastid data.

8.1.1. Restio pedicellatus Mast. in Journal of the Linnean Society, Botany 8: 252 (1865).

8.1.2. Restio echinatus Kunth, Enumeratio plantarum 3: 384 (1841).

8.1.3. Restio stereocaulis Mast. in Botanische Jahrbücher 29 Beiblatt 66: 1 (1900b). 
8.1.4. Restio subtilis Nees ex Mast. in Journal of the Linnean Society, Botany 8: 251 (1865).

8.1.5. Restio confusus Pillans in Journal of South African Botany 18: 103 (1952).

8.1.6. Restio miser Kunth, Enumeratio plantarum 3: 392 (1841).

8.1.7. Restio distylis H.P.Linder \& C.R.Hardy, nom. nov. pro Leptocarpus esterhuyseniae Pillans in Transactions of the Royal Society of South Africa 30: 260 (1945). Calopsis esterhuyseniae (Pillans) H.P.Linder: 466 (1985). Type: Mitchell's Pass, Slab Peak, Esterhuysen 6211 (BOL, holo.!; K!), non Restio esterhuyseniae Pillans.

Named for the unusual condition of having two styles.

8.1.8. Restio monostylis (Pillans) H.P.Linder \& C.R.Hardy, comb. nov.

Leptocarpus monostylis Pillans in Journal of South African Botany 18: 108 (1952). Calopsis monostylis (Pillans) H.P.Linder: 469 (1985). Type: south slopes of the Langeberg near Riversdale, Esterhuysen 16993 (BOL, holo.!).

8.1.9. Restio papyraceus Pillans in Transactions of the Royal Society of South Africa 29: 342 (1942).

8.1.10. Restio nuwebergensis Esterh. in Linder in Bothalia 15: 453 (1985).

8.1.11. Restio bifarius Mast. in Journal of the Linnean Society, Botany 10: 278 (1868).

8.1.12. Restio bifidus Thunb., Phytographische Blätter, Göttingen 1: 7 (1803).

8.2. Restio subgen. Pendulostemon H.P.Linder \& C.R.Hardy, subgen. nov., primo adspectu Restioni, Craspedolepi, Calopsi, Locapsi, Varirestioni et Eremorestioni culmis rotundis, ramificantibus, vaginis persistentibus, staminodiis praesentibus, stylis libris maxime simile, sed a speciebus olim ad subgenera Restionem vel Calopsem ascriptis combinatione spiculorum marium pendulorum cum tepalis femineis glabris spiculisque femineis grandibus striis longitalibus instructis differt.

\section{TYPE._-Restio micans Nees.}

Plants tufted or clumped. Fertile culms branching, round; sheaths persistent, closely convoluted, margins similar to body of bracts or narrowly membranous. Male inflorescence paniculate, with 6-50 pendulous spikelets; bracts \pm leathery, overtopping flowers. Female inflorescences usually racemose, with up to 20 erect, elliptical or obovate, rounded to acute, several-flowered spikelets; bracts at least as tall as flowers, imbricate, usually with longitudinal striations, margins like body or narrowly membranous. Female flowers laterally compressed; tepals bony or cartilaginous, glabrous, outer lateral tepals usually conduplicate and keeled; staminodes present. Gynoecium with 3 , white, feathery, free styles; ovary with 2 locules, dehiscent. Seed silvery or pink, smooth or colliculate. Culm anatomy: epidermis single-layered, epidermal lateral cell walls straight, unthickened; parenchyma 1-5-layered; central ground tissue solid or with single, central cavity; tannin found in epidermis or sclerenchyma or central ground tissue; silica absent or present in parenchyma.

Etymology: Pendulostemon (m.): pendulo (Latin), pendulous; stemon (Greek), stamen; referring to the pendulous male spikelets.
Notes: the two species of this subgenus mentioned below were previously included in Restio s.str. because of their dehiscent ovaries, laterally flattened flowers and branched culms. Their current position is uncertain, but plastid data weakly indicate a relationship to Thamnochortus and Rhodocoma (Figure 2) with which they share the pendulous male spikelets. However, a closer relationship to Restio s.str. cannot be rejected.

Although the two species had not previously been associated, they share a number of morphological attributes. The plants are rather untidy, erect tussocks with robust, erect, branching culms. The sheaths are coriaceous without a substantial membranous margin. The spikelets, both male and female, are spindle-shaped and relatively large. The male spikelets are pendulous. The only unique feature is the longitudinal striation on the bracts, but this feature is not always easy to observe. Restio micans is a rare species on coastal sands, $R$. egregius is more widespread in the wetter mountains of the Western Cape.

8.2.1. Restio egregius Hochst. in Krauss in Flora 28: 337 (1845).

8.2.2. Restio micans Nees in Linnaea 5: 649 (1830).

8.3. Restio subgen. Craspedolepis (Steud.) H.P.Linder \& C.R.Hardy, stat. nov.

Craspedolepis Steud., Synopsis plantarum glumacearum 2: 264 (1855). Type: Craspedolepis verreauxii Steud. (= Restio filiformis Poir.).

Plants caespitose to tangled, without spreading rhizomes. Fertile culms mostly branching, round or rarely compressed; sheaths persistent, usually closely convoluted, apical margin \pm membranous, sometimes with large membranous shoulders flanking mucro. Male inflorescence racemose or paniculate, with up to 10 (rarely more) usually erect, mostly elliptical, spikelets ( $2 \mathrm{spp}$. with pendulous spikelets); male bract with upper margin usually with honeycombed cells, which eventually decay, taller than flowers; anthers exserted from flowers at anthesis. Female inflorescence similar to males, but spikelets are somewhat bigger, mostly elliptical, with up to 40 flowers; female bracts imbricate, shorter to taller than flowers, apical margin with honeycombed cells. Female flowers: outer tepals differentiated into conduplicate lateral tepals and a flat odd tepal, rarely glabrous and smooth, usually densely villous on keels of conduplicate tepals, occasionally also on back of outer odd tepal; staminodes present. Gynoecium with 3, white, feathery styles free to base; ovary usually with 2 , rarely 3 or 1 , fertile locules, dehiscent. Seed variously coloured, surface smooth or colliculate. Culm anatomy: epidermal cells 1-layered, lateral wall straight and unthickened or sinuose and thickened; parenchyma up to 4-layered; central ground tissue usually solid; tannin usually present in epidermis, sclerenchyma and central ground tissue; silica usually absent.

Etymology: Craspedolepis (f.): kraspedon (Greek), edge, border or fringe; lepis (Greek), scale. This name may be interpreted to refer to the upper margin of the floral bracts (scales) which differ from the body of the bract by the honeycombed cells, and are thus bordered.

Notes: this is a very distinctive segregate from Restio s.str. The most notable synapomorphy are the hollow 
cells (honeycomb cells) that form the upper margins of the floral bracts. This is absent from one species in the subgenus, and similar structures are also found in a few species in two other subgenera. The other characters are more in the nature of 'tendencies': large, elliptical spikelets (where Restio insignis and $R$. strobilifer are extreme examples); very hairy tepals, with often all three outer tepals hairy along the keels; almost always with two fertile locules. This contrasts with Restio s.str. with its tendency to unilocular, indehiscent or tardily dehiscent ovaries.

The subgenus is widespread especially in the western half of the Cape Floristic Region (CFR), and is almost absent from the eastern parts of the CFR. There is a remarkable range of seed surface ornamentation, from colliculate to smooth. The inflorescence structure is also highly variable, from solitary spikelets, to manyspikeletted, paniculate structures.

The species are organized into several poorly separated subgroups (Figure 4).

a) Restio fusiformis group: seed triangular in cross section, either smooth or colliculate. The female spikelets are rather diverse in appearance:

8.3.1. Restio inveteratus Esterh. in Linder in Bothalia 15: 450 (1985).

8.3.2. Restio obscurus Pillans in Transactions of the Royal Society of South Africa 29: 341 (1942).

8.3.3. Restio fusiformis Pillans in Journal of South African Botany 18: 104 (1952).

8.3.4. Restio acockii Pillans in Transactions of the Royal Society of South Africa 29: 339 (1942).

8.3.5. Restio praeacutus Mast. in Flora capensis 7: 84 (1897)

8.3.6. Restio rupicola Esterh. in Linder in Bothalia 15: 459 (1985).

b) Restio perseverans group: inner male tepals shorter than the outer; seed triangular in cross section, surface ornamentation smooth:

8.3.7. Restio perseverans Esterh. in Linder in Bothalia 15: 457 (1985).

c) Restio aureolus group: female flowers only sparsely hairy, seeds planoconvex in cross section, surface ornamentation smooth. This includes $R$. occultus, with numerous few-flowered spikelets in paniculate inflorescences and richly branched plants.

8.3.8. Restio aureolus Pillans in Transactions of the Royal Society of South Africa 30: 246 (1945).

8.3.9. Restio perplexus Kunth, Enumeratio plantarum 3: 406 (1841).

8.3.10. Restio pulvinatus Esterh. in Linder in Bothalia 15: 457 (1985).

8.3.11. Restio cymosus (Mast.) Pillans in Annals of the Bolus Herbarium 3,2: 85 (1921).

8.3.12. Restio capillaris Kunth, Enumeratio plantarum 3: 405 (1841).

8.3.13. Restio patens Mast. in Flora capensis 7:97 (1897).

8.3.14. Restio brachiatus (Mast.) Pillans in Annals of the Bolus Herbarium 3,2: 85 (1921).
8.3.15. Restio occultus (Mast.) Pillans in Transactions of the Royal Society of South Africa 16: 243 (1928).

d) Restio filiformis group: seed triangular in cross section, surface ornamentation colliculate. In this group the female spikelets are compact, globose to elliptical, often rather few:

8.3.16. Restio filiformis Poir. in Lam., Encyclopédie méthodique. Botanique 6: 173 (1804).

8.3.17. Restio brunneus Pillans in Transactions of the Royal Society of South Africa 16: 250 (1928).

8.3.18. Restio burchellii Pillans in Transactions of the Royal Society of South Africa 29: 340 (1942).

8.3.19. Restio insignis Pillans in Transactions of the Royal Society of South Africa 30: 251 (1945).

8.3.20. Restio pachystachyus Kunth, Enumeratio plantarum 3: 399 (1841).

8.3.21. Restio strobilifer Kunth, Enumeratio plantarum 3: 398 (1841).

8.3.22. Restio nodosus Pillans in Transactions of the Royal Society of South Africa 30: 252 (1945).

8.3.23. Restio bifurcus Nees ex Mast. in Journal of the Linnean Society, Botany 8: 247 (1865).

8.3.24. Restio bolusii Pillans in Transactions of the Royal Society of South Africa 16: 247 (1928).

8.4. Restio subgen. Varirestio H.P.Linder \& C.R. Hardy, subgen. nov., primo adspectu Restioni, Craspedolepi, Calopsi, Locapsi et Eremorestioni culmis rotundis, ramificantibus, vaginis persistentibus, spiculis maribus erectis, staminodiis praesentibus, stylis 3 , libris, ovario loculis 1 vel 3, dehiscentibus maxime simile, sed vaginis interdum mucronibus pro ratione longis (longioribus quam dimidia pars vaginae) munitis differt et praeterea positio topologica recognitionem subgeneris cogit.

\section{TYPE.-Restio debilis Nees.}

Plants caespitose. Fertile culms branching or rarely simple, round; sheaths persistent, closely to very loosely convoluted; apical margins undifferentiated or forming membranous lobes; mucro sometimes as long as body of sheath. Male inflorescences racemose to paniculate, with up to 10 erect spikelets; spathes often overtopping spikelets; bracts with upper margins sometimes with honeycombed cells; anthers exserted from flowers at anthesis. Female inflorescence basically similar to male, but with fewer and larger spikelets; spikelets oblong, elliptical, ovate or obovate, with up to 20 flowers; bracts shorter or longer than flowers, apical margin sometimes with honeycombed cells. Female flowers laterally compressed; outer lateral tepals conduplicate, outer odd tepal flat, laterals either glabrous or villous; staminodes present. Gynoecium: with 3, white, feathery styles, free to base; ovary with 1 or 3 dehiscent locules. Seed variously coloured, smooth or colliculate. Culm anatomy: epidermal cells 1-layered, lateral wall straight and unthickened or more rarely sinuose and thickened; parenchyma 1- or 2-layered; central ground tissue solid or with a single, central cavity; tannin, when present, found in epidermis, sclerenchyma or central ground tissue; silica absent.

Etymology: Varirestio (m.): vari (Latin), various, variable; restio (Latin), ropemaker; the name reflects the extremely heterogeneous nature of this subgenus. 


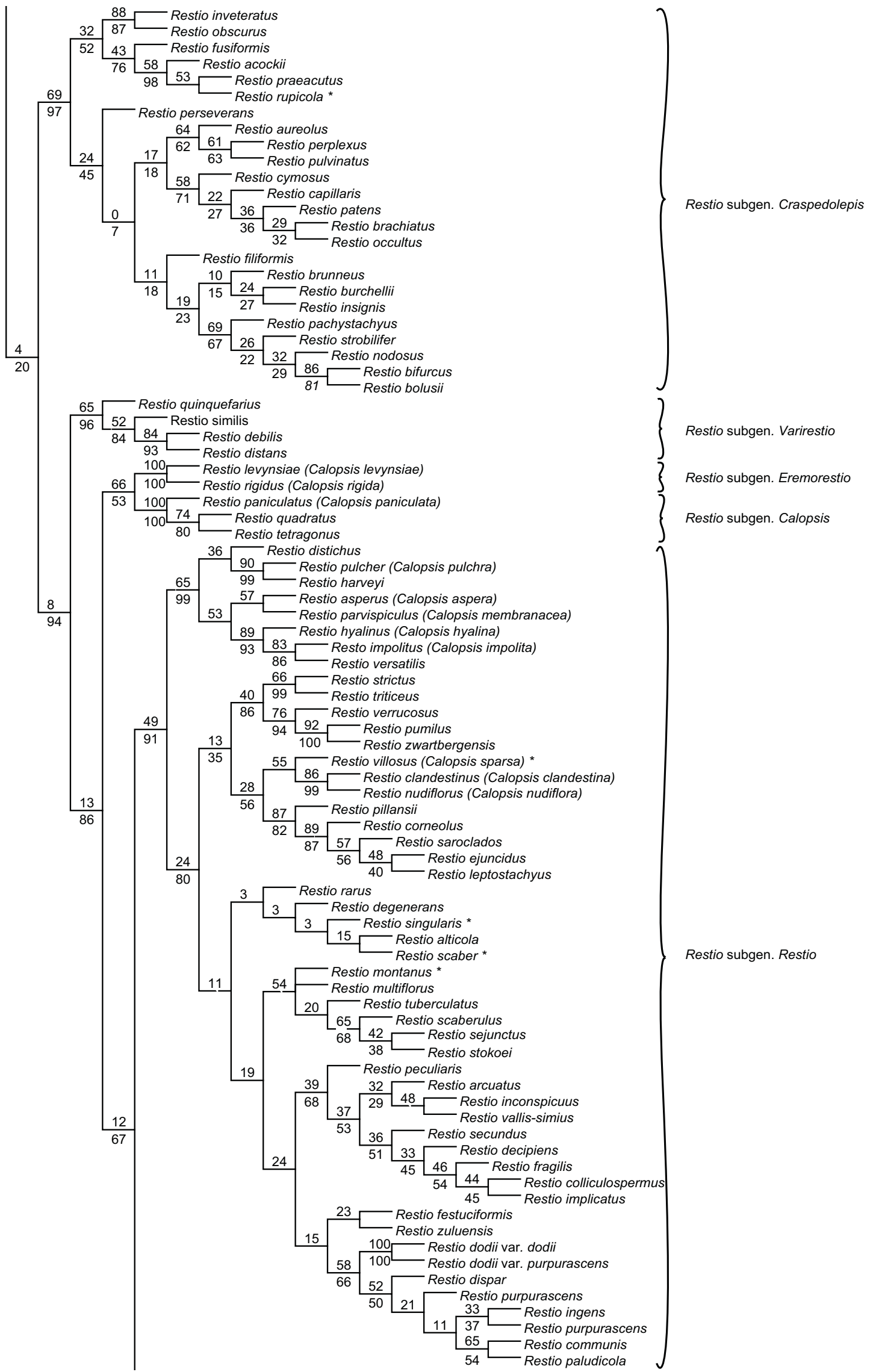

FIGURE 4.-Portion of strict consensus tree of total combined analysis of Hardy et al. (2008) containing Restio subgen. Craspedolepis, R. subgen. Varirestio, $R$. subgen. Eremorestio, $R$. subgen. Calopsis, and $R$. subgen. Restio. Names in parentheses are the now synonymous names of Linder (2001a) when different from the ones here proposed. Bootstrap values above the branches indicate support based on a 500-replicate bootstrap analysis that included 20 species for which DNA data were lacking (asterisked taxa). Bootstrap values below branches indicate support based upon a 500-replicate analysis that included only taxa for which both DNA data and morphology data were available. Where no value is given below a branch, it indicates that the clade did not appear in the analysis excluding morphology-only species. 
Notes: recognition of this subgenus is forced by its topological position, sister to distinctive subgenera such as Ischyrolepis, Locapsis, Restio and Calopsis. Its four species appear not to share any unique attributes, and are morphologically very divergent. There is no morphological support for the recognition of this clade. Of the four species, two have three locules and two just one; two species have exceptionally long mucros, the others short mucros. Similarly there is no homogeneity in the anatomy or the seed colour or ornamentation. Nor is there a pattern of variation that would allow the recognition of two diagnosable taxa.

8.4.1. Restio quinquefarius Nees in Linnaea 5: 639 (1830).

8.4.2. Restio similis Pillans in Annals of the Bolus Herbarium 3,2: 82 (1921).

8.4.3. Restio debilis Nees in Linnaea 5: 641 (1830).

8.4.4. Restio distans Pillans in Transactions of the Royal Society of South Africa 30: 247 (1945).

8.5. Restio subgen. Calopsis (Beauv. ex Desv.) H.P. Linder \& C.R.Hardy, stat. nov.

Calopsis Beauv. ex Desv., Annales des Sciences Naturelles 13: 44, t. 3 (1828). Type: Calopsis paniculata (Rottb.) Desv. (= Restio paniculatus Rottb.).

Large plants with large rhizomes. Fertile culms branching, square or at least in upper parts semicircular, always somewhere angular; sheaths persistent, with no abscission line, closely convoluted, apical margins either coriaceous like rest of body, or with large acute hyaline shoulders flanking the penicillate mucro. Male and female inflorescence very similar, racemose to paniculate, with very many partial inflorescences terminating apical part of fertile shoot, each with 1 to many elliptical to oblong, many-flowered spikelets. Male flowers with anthers exserted at anthesis. Female spikelets with up to 14 flowers; bracts shorter than, to as long as, flowers, margins not differentiated; outer lateral tepals conduplicate, keels glabrous to sparsely villous; staminodes present. Gynoecium with 3, white, feathery styles, free to base; ovary with 1-3 locules, indehiscent or dehiscent, or sometimes dropping with seed. Seed brown and smooth. Culm anatomy: epidermal cells single-layered, lateral walls straight and unthickened; parenchymatous layer of 1 or 2 cells; central ground tissue solid or with single, central cavity; tannin present in epidermis, parenchyma, sclerenchyma, or central ground tissue; silica present in parenchyma or central ground tissue.

Etymology: Calopsis (f.): calos (Greek), beautiful; opsis (Greek), aspect; they are quite striking plants, consequently the generic name Calopsis (= looking beautiful) is highly appropriate.

Notes: this is a dramatically redefined concept of Calopsis, as it excludes the whole genus as currently recognized except the type species, and includes two species formerly placed in Restio. However, the three species share a very similar growth form: one can think of them as being huge paniculate inflorescences of which the lower portion is sterile. Segregating them into separate genera was based on an over-reliance on the ovary dehiscence (Restio with capsules, Calopsis with nuts). Furthermore, in all three species the culms are more or less angular, and in two of them they are sharply square. All three species are associated with ground water, and C. paniculata is a typical streambank species, widespread in the CFR.

8.5.1. Restio paniculatus Rottb., Descriptions plantarum rariorum 10 (1772).

8.5.2. Restio quadratus Mast. in Journal of the Linnean Society, Botany 10: 277 (1868).

8.5.3. Restio tetragonus Thunb., Dissertatione de Restione: 17 (1788).

8.6. Restio subgen. Eremorestio H.P.Linder \& C.R. Hardy, subgen. nov., Calopsi sensu Linder (1984) vaginis persistentibus, antheris exsertis, ovariis unilocularibus indehiscentibus affinis, sed combinatione vaginorum arcte convolutorum, cum nuce triquetra, $2-3 \mathrm{~mm}$ longa differt.

\section{TYPE.—Calopsis rigida (Mast.) H.P.Linder.}

Plants tufted or mat-forming. Fertile culms branching, round; sheaths persistent, closely convoluted, upper half more membranous than lower half, soon decaying. Male inflorescence racemose or sparsely paniculate with 2-20 \pm elliptical spikelets; spathes persistent, sometimes taller than spikelets; bracts acute to acuminate, slightly taller than flowers, apices somewhat darker than bodies; anthers exserted from flowers at anthesis. Female inflorescence similar to males, but always racemose and with fewer, somewhat larger spikelets; bracts taller than flowers, bony or cartilaginous, acute to acuminate, apices recurved somewhat from spikelet, giving it a bristly appearance; flowers laterally compressed; tepals chartaceous, rounded, glabrous or keels of lateral sepals sparsely villous; staminodes present. Gynoecium with 3 , white, feathery styles free to base; ovary unilocular, indehiscent. Diaspore a soft-walled nut enclosed in perianth, triangular, 2-3 mm long, perianth not winged. Culm anatomy: epidermal cells 1-layered, lateral wall straight, unthickened; parenchymatous layer of 2 or 3 cells; central ground tissue solid; tannin, when present, in epidermis or central ground tissue; silica absent.

Etymology: Eremorestio (m.): Eremia (Greek), desert; Restio (Latin), ropemaker; restios living in arid areas, referring to the habitat of the two species in this genus, occurring along the arid margins of the Cape Floristic Region.

Notes: similar to the situation in Varirestio, this subgenus of two species is recognized in order to be able to separate the larger subgenera Restio s.str. and Ischyrolepis. Contrary to the situation in Varirestio, however, there are numerous similarities between the two species. They have similar diaspores (soft-walled nuts dispersed in a papery perianth). Such diaspores defined the genus Calopsis sensu Linder 1984. The papery perianth and rather brittle bracts are also typical of this group. Morphologically the genus is very close to Locapsis, and it is not clear whether monophyly would be significantly rejected if the two were combined. The morphological distinction between Eremorestio and Locapsis is not easy, as most of the characteristics of Eremorestio are also found in the larger subgen. Locapsis. Possibly the best attribute could be that the tips of the floral bracts in the 
two species of Eremorestio are darker than the bodies of the bracts, and these tips are recurved away from the axis of the spikelet. In Locapsis the bract tips are generally the same colour as the body of the bracts, and the tips are closely rolled around the spikelets, resulting in slender spindle-shaped spikelets. However, it is not clear whether this attribute will be a useful, consistent key character.

These two species also occupy a typical Locapsis habitat, along the arid fringes of the Cape. They have a disjunct distribution, with Restio levynsiae in the Swartruggens Mountains, and $R$. rigidus from the Voetpadsberg near Laingsburg to the Great Swartberg.

\subsubsection{Restio levynsiae (Pillans) H.P.Linder \& C.R.} Hardy, comb. nov.

Leptocarpus levynsiae Pillans in Transactions of the Royal Society of South Africa 29: 346 (1942). Calopsis levynsiae (Pillans) H.P.Linder: 467 (1985). Type: Katbakkies, Levyns 1845 (BOL, holo.!).

8.6.2. Restio rigidus (Mast.) H.P.Linder \& C.R.Har$d y$, comb. nov.

Leptocarpus rigida Mast. in Botanische Jahrbücher 29, Beiblatt 66: 10 (1900b). Calopsis rigida (Mast.) H.P.Linder: 470 (1985). Type: Koue Bokkeveld, Schlechter 8882, 8883 (K, lecto.! [Linder in Bothalia 15: 470 (1985)]; BM!, BOL!, BR!, K!, P!, S!, WAG!, Z!).

\subsection{Restio subgen. Restio}

Plants caespitose, clumped, tangled or mat-forming. Fertile culms branching (with the sole exception of $R$. strictus), round; sheaths persistent, closely or loosely convoluted, usually with a narrow membranous margin, often with tall, acute, membranous lobes flanking mucro. Male and female inflorescences mostly very similar; mostly paniculate, more rarely racemose, with 1 to numerous spikelets; spathes usually persistent, often overtopping spikelets; bracts varying from shorter to taller than flowers, without honeycombed cells in apical parts; anthers exserted from flowers at anthesis. Female inflorescence occasionally with fewer spikelets than males; spikelets with up to 16 laterally compressed flowers; tepals chartaceous or cartilaginous, glabrous or sparsely (rarely densely) villous on keels of lateral sepals; staminodes present. Gynoecium with 3, white, feathery styles free to base or rarely seated on a stylopodium; ovary mostly unilocular, rarely with 2 locules, only in $R$. sejunctus with 3 locules, either dehiscent or indehiscent. Diaspore either a seed or a soft-walled nut; seed variously coloured, usually smooth, occasionally colliculate; nut dropped with a persistent papery perianth that is sometimes winged. Culm anatomy: epidermal cells 1-layered, lateral walls usually straight and unthickened, occasionally sinuose and thickened; parenchymatous layer of up to 6 cells; central ground tissue either with no cavity, a single central cavity, or with scattered cavities; tannin rarely absent, when present then in the epidermis, sclerenchyma, or central ground tissue; silica either absent, or when present, in chlorenchyma or parenchyma.

Notes: Restio, as defined here, is still a very broad subgenus, including species from Calopsis and Restio sensu Linder 1984. Broadly speaking, it includes the generally more slender members of Restio s.lat., with a tendency towards small spikelets, to unilocular and often indehiscent ovaries, and to more membranous sheaths and bracts. This contrasts to subgen. Craspedolepis, which includes the more robust Restio species.
Although there are no clearcut synapomorphies for the subgenus, there are a number of attributes which in combination will often lead to a correct identification. Most species in the subgenus have tall membranous lobes flanking the mucro on the sheath. These are also found in many other genera (e.g. subgen. Ischyrolepis), but are rare in the other segregates of Restio s.lat. In Restio s.str. they are optimized as being ancestrally present. As such, this character can be seen as a synapomorphy for the subgenus, although it cannot be used to key out the subgenus, due to the absence of this feature from many species of Restio, and its presence in many species in other genera. In most species in the subgenus there is a single functional locule. Furthermore, in most cases this locule is also dehiscent. Typical of the subgenus are rather small spikelets, often with few flowers, rather than the more massive spikelets characteristic of Craspedolepis.

Ecologically most species are found along the wetter coastal mountains, where they often form an understorey under other vegetation.

Despite the substantial variation in the subgenus, it is not possible to formally recognize sections, but to facilitate an understanding of the variation in this large taxon, the species are placed into informal groups.

a) Restio aspera group: mostly ex-Calopsis species, with paniculate inflorescences, rounded tepal apices, tepals sometimes winged, and indehiscent ovaries:

\subsubsection{Restio distichus Rottb., Descriptiones plantarum} rariorum 11 (1772).

\subsubsection{Restio pulcher (Esterh.) H.P.Linder \& C.R.}

\section{Hardy, comb. nov.}

Calopsis pulchra Esterh. in Linder in Bothalia 15: 469 (1985). Type: along road from Elim to Stanford, Esterhuysen 31255 (BOL, holo.!; B!, BOL!, C!, E!, F, GRA!, K!, L, LD, M!, MO!, NBG!, NY, PRE!, RSA, S!, STE!, TCD!, UC, US, W!, WAG!).

8.7.3. Restio harveyi Mast. in Journal of the Linnean Society, Botany 8: 253 (1865).

\subsubsection{Restio asperus (Mast.) H.P.Linder \& C.R.Har-} $d y$, comb. nov.

Hypolaena aspera Mast. in Journal of the Linnean Society, Botany 10: 264 (1868). Calorophus asper (Mast.) Kuntze: 747 (1891). Leptocarpus asper (Mast.) Pillans: 345 (1928). Calopsis aspera (Mast.) H.P.Linder: 465 (1985). Type: Nieuw Kloof, Houw Hoek, Burchell 8069 (K, lecto.! [Linder in Bothalia 15: 465 (1985)]; BOL!, K!, P!); Hottentots Holland Mtns, Ecklon \& Zeyher s.n. (K!); s.loc. Thom 632 (K!); mountains at Grietjiesgat, Ecklon \& Zeyher s.n. (K!); Palmiet River, Ecklon 951 (B!).

\subsubsection{Restio parvispiculus H.P.Linder \& C.R.Har-} $d y$, nom. nov.

Hypolaena burchellii Mast. in Journal of the Linnean Society, Botany 10: 268 (1868). Calorophus burchellii (Mast.) Kuntze: 747 (1891). Leptocarpus membranaceus Pillans: 346 (1928). Type: Nieuw Kloof, Houw Hoek Mtns, Burchell 8116 (BOL!, K!); Baviaanskloof Mtns, near Genadendal, Burchell 7894a (BOL!, K!, P!); 7632 (K, lecto.! [Linder in Bothalia 15: 469 (1985)]; BOL!), non Restio burchellii Pillans et Restio membranaceus Nees (= Elegia intermedia (Steud.) Pillans.

\subsubsection{Restio hyalinus (Mast.) H.P.Linder \& C.R.}

Hardy, comb. nov.

Hypolaena hyalina Mast. in Botanische Jahrbücher 29, Beiblatt 66: 13 (1900b). Leptocarpus hyalinus (Mast.) Pillans: 344 (1928). Mastersiella hyalina (Mast.) Gilg-Ben.: 25 (1930). Calopsis hyalina (Mast.) H.P.Linder: 467 (1985). Type: Koude River, Schlechter 10464, 
10465 (K, lecto.! [Linder in Bothalia 15: 467 (1985)]; BOL!, BR!, MEL!, MO!, NBG!, P!, S!, WAG!, Z!).

8.7.7. Restio impolitus Kunth, Enumeratio plantarum 3: 404 (1841).

8.7.8. Restio versatilis H.P.Linder in Bothalia 15: 463 (1985).

b) Restio triticeus group: has dehiscent unilocular ovaries. Two subgroups are recognized, one of which has colliculate seed (rather than the smooth seed typical of the rest of the genus):

8.7.9. Restio strictus N.E.Br. in Flora capensis 7: 752 (1900).

8.7.10. Restio triticeus Rottb., Descriptiones plantarum rariorum 11 (1772).

8.7.11. Restio verrucosus Esterh. in Linder in Bothalia 15: 462 (1985)

8.7.12. Restio pumilus Esterh. in Linder in Bothalia 15: 458 (1985).

8.7.13. Restio zwartbergensis Pillans in Transactions of the Royal Society of South Africa 16: 229 (1928).

8.7.14. Restio villosus H.P.Linder \& C.R.Hardy, nom. nov. pro Calopsis sparsa Esterh. in Linder in South African Journal of Botany 56: 454 (1990). Type: Caledon Div., Arieskraal, Esterhuysen 32751 (BOL, holo.!, B!, C!, E!, K!, L!, M!, MO!, PRE!, S!, STE!, UPS!), non Restio sparsus Mast. (= Restio strobilifer Kunth).

The name refers to the uniquely villous flower bases.

8.7.15. Restio clandestinus (Esterh.) H.P.Linder \& C.R.Hardy, comb. nov.

Calopsis clandestina Esterh. in Linder in Bothalia 15: 465 (1985). Type: mountain above Harold Porter Reserve, Esterhuysen 34146 (BOL, holo.!, B!, C!, E!, F, GRA!, K!, L, M!, MO!, NBG!, NY, PRE, RSA, S!, STE!, TCD!, UC, US, W!, WAG!)

8.7.16. Restio nudiflorus (Pillans) H.P.Linder \& C.R.Hardy, comb. nov.

Leptocarpus nudiflorus Pillans in Transactions of the Royal Society of South Africa 30: 261 (1945). Calopsis nudiflora (Pillans) H.P.Linder: 469 (1985). Type: Somerset Sneeukop, Esterhuysen 8230 (BOL, holo.!; K!)

8.7.17. Restio pillansii H.P.Linder in Bothalia 15: 457 (1985).

8.7.18. Restio corneolus Esterh. in Linder in Bothalia 15: 443 (1985).

8.7.19. Restio saroclados Mast. in A.DC., Monographiae phanerogamarum 1: 291 (1878).

8.7.20. Restio ejuncidus Mast. in Botanische Jahrbücher 29, Beiblatt 66: 2 (1900b).

8.7.21. Restio leptostachyus Kunth, Enumeratio plantarum 3: 407 (1841).

c) Restio multiflorus group: bracts ovate, margins ciliate or shallowly toothed; ovaries with 2(3) locules:

8.7.22. Restio montanus Esterh. in Linder in Bothalia 15: 453 (1985).

8.7.23. Restio multiflorus Spreng., Systema vegetabilium 1: 187 (1824)

8.7.24. Restio tuberculatus Pillans in Annals of the Bolus Herbarium 3,3: 146 (1922).

8.7.25. Restio scaberulus N.E.Br. in Flora capensis 7: 751 (1900).
8.7.26. Restio sejunctus Mast. in Flora capensis 7: 97 (1897).

8.7.27. Restio stokoei Pillans in Transactions of the Royal Society of South Africa 16: 231 (1928).

d) Restio dodii group: spathes taller than the spikelets, plants often very fine and tangled, ovaries unilocular and dehiscent:

8.7.28. Restio rarus Esterh. in Linder in Bothalia 15: 459 (1985).

8.7.29. Restio degenerans Pillans in Transactions of the Royal Society of South Africa 30: 246 (1945).

8.7.30. Restio singularis Esterh. in Linder in Bothalia 15: 460 (1985).

8.7.31. Restio alticola Pillans in Journal of South African Botany 19: 101 (1952).

8.7.32. Restio scaber Mast. in Botanische Jahrbücher 29, Beiblatt 66: 1 (1900b).

8.7.33. Restio peculiaris Esterh. in Linder in Bothalia 15: 455 (1985).

8.7.34. Restio arcuatus Mast. in A.DC., Monographiae phanerogamarum 1: 247 (1878).

8.7.35. Restio inconspicuus Esterh. in Linder in Bothalia 15: 449 (1985).

8.7.36. Restio vallis-simius H.P.Linder in Bothalia 15: 462 (1985).

8.7.37. Restio secundus (Pillans) H.P.Linder in Bothalia 15: 460 (1985).

8.7.38. Restio decipiens (N.E.Br.) H.P.Linder in Bothalia 15: 444 (1985).

8.7.39. Restio fragilis Esterh. in Linder in Bothalia 15: 447 (1985).

8.7.40. Restio colliculospermus H.P.Linder in Bothalia 15: 443 (1985).

8.7.41. Restio implicatus Esterh. in Linder in Bothalia 15: 447 (1985).

8.7.42. Restio festuciformis Nees ex Mast. in Journal of the Linnean Society, Botany 8: 248 (1865), as festucaeformis.

8.7.43. Restio zuluensis H.P.Linder in Bothalia 15: 463 (1985).

8.7.44a. Restio dodii Pillans in Annals of the Bolus Herbarium 3,2: 85 (1921) var. dodii.

8.7.44b. Restio dodii Pillans var. purpurascens Pillans in Transactions of the Royal Society of South Africa 16: 252 (1928)

8.7.45. Restio dispar Mast. in Journal of the Linnean Society, Botany 8: 246 (1865).

8.7.46. Restio purpurascens Nees ex Mast. in Journal of the Linnean Society, Botany 8: 249 (1865).

8.7.47. Restio ingens Esterh. in Linder in Bothalia 15: 449 (1985).

8.7.48. Restio communis Pillans in Transactions of the Royal Society of South Africa 16: 264 (1928).

8.7.49. Restio paludicola H.P.Linder, sp. nov., a $R$. communis spiculis maribus minoribus (8-10 mm longis), paucifloris (1 vel 2) differt.

TYPE.-Western Cape, 3419 (Caledon): Caledon Div., Hermanus Mountain, on rocky banks of a small perennial stream, overlooking coast, growing quite densely in places, $1-2 \mathrm{ft}[0.3-0.6 \mathrm{~m}]$ tall, $\pm 1000 \mathrm{ft}[300 \mathrm{~m}],(-$ AC), 26-08-1973, Esterhuysen 33222 (BOL, holo.). 
Plants mat-forming or tangled, stoloniferous. Fertile culms sparsely branched, finely to roughly warty, green or olivaceous, $0.3-0.8 \mathrm{~m}$ long, $0.1-0.7 \mathrm{~mm}$ diam. at apex; sheaths closely convoluted, $10-35 \mathrm{~mm}$ long, reddish brown with golden mottling, tuberculate, apical margins truncate, coriaceous, hyaline shoulders up to half as long as sheath, acute; mucro penicillate, straight and erect or recurved, 3-9 $\mathrm{mm}$ long. Male inflorescence racemose, with 2-10 spikelets, 40-80 mm long; spathes chartaceous, reddish brown with a golden speckling, persistent, taller than spikelets; spikelets sessile, obovate (obtriangular), rounded, 8-10 mm long, 1- or 2-flowered; bracts longer than flowers, 3-6 mm long, linear or oblong, acute, chartaceous, bract with upper margin like body of bract, bract awn minute or absent. Male flower 2.0-3.5 mm long; outer tepals cartilaginous; inner tepals shorter than outer, membranous, outer lateral tepals conduplicate or as other tepals, glabrous or keel sparsely villous (visible only under higher magnification); anthers 1.2-1.5 mm long, exserted from flowers; pistillode present. Female inflorescence racemose, with 2-10 spikelets, 30-80 $\mathrm{mm}$ long; spathes longer than spikelets, persistent, cartilaginous; spikelet sessile, obtriangular, truncate, 9-14 mm long, mostly single-flowered, rarely 2- or 3-flowered; bracts at least as tall as flowers, 5-9 mm long, linear or oblong, acute, chartaceous, awn minute or absent. Female flower $3.5-4.0 \mathrm{~mm}$ long; tepals cartilaginous, glabrous and smooth or keels of lateral sepals sparsely villous, apices acute, inner and outer whorls same length, 3.5-4.0 mm long; odd outer tepal linear or oblong, inner tepals linear or oblong; staminodes present. Gynoecium: styles feathery, white, 3, free to base; ovary unilocular, dehiscent. Seed 1.6-1.7 × 0.9-0.95 $\mathrm{mm}$, elliptical in side view, triangular in cross section, tan or pink, smooth (shiny). Culm anatomy: epidermal cells 1-layered, lateral walls straight, unthickened, outer wall thickened, colliculate, glabrous, $1 / \mathrm{w}$ ratio $2.5: 1.5$; stomatal apparatus superficial, guard cells seated on top of support cells; chlorenchyma of 2 layers of cells, 1/w ratio $5: 3$, inner and outer layers similar; protective cells reaching to base of chlorenchyma layer; parenchymatous layer of 1 or 2 cells, cells smaller than epidermal cells; sclerenchyma with 4-7 layers of cells, without protrusions; central ground tissue with scattered cavities; tannin found in epidermis, sclerenchyma or central ground tissue; silica sand in chlorenchyma (where protective cells touch parenchyma). Flowering time: March or April; seed release in August or September.

Distribution and ecology: restricted to the Kleinrivierberge behind Hermanus, in the Western Cape, where it is found at an altitude of 300-700 m, on Table Mountain Sandstone. The species is restricted to wet habitats, in seepages with Roridula, and along stream margins. These are found on the south-facing upper slopes of these low mountains, where they receive ample rain throughout the year. The plants grow into a dense tangled understorey under the other vegetation.

Notes: the new species is very close to Restio communis from the Cape Peninsula, but it differs in the less robust spikelets, the more slender flowers, and the smaller female bracts. The male spikelets are $8-10 \mathrm{~mm}$ long (instead of $15-20 \mathrm{~mm}$ ), and have only 1 or 2 flowers (instead of 6-12 flowers), and the male flowers are $2.0-3.5 \mathrm{~mm}$ long (instead of 3.6-4.0 $\mathrm{mm}$ long). There is a single collection from the Caledon Swartberg, which might be intermediate, or which might constitute yet another segregate.

Etymology: paluster (Latin), marshy; cola (Latin), dweller in; referring to the habitat of the species in boggy places.

\section{Additional collections}

WESTERN CAPE.-3419 (Caledon): Hermanus Mountain, Roridula Stream, forming a dense undergrowth in wet seepages, (-AC), 1605-1999, H.P.Linder 6933 (Z); Caledon, above Vogelklip Kloof, Hermanus, banks of small open stream, diffuse, amongst shrubs, (-AD), 18-11-1973, Esterhuysen 33352 (BOL); Caledon, Klein River Mtns, nr Hermanus, Rocklands Peak area, in small marsh, on stream banks, (-AD), 03-05-1971, Esterhuysen 32572 (BOL); Caledon, Maanschyn Kop (Rocklands Kop), \pm 1 mile [1.6 km] E of summit peak; in small marsh below upper slopes of ridge, (-AD), 08-10-1967, Esterhuysen 31732 (BOL); Caledon, Maanschyn Kop, between Hermanus and Stanford, in small marsh on E slopes, (-AD), 22-02-1968, Esterhuysen $31930 a$ (BOL); Caledon, Swartberg, at base of marsh, on N slope, over ridge, (-AB), 13-03-1976, Esterhuysen 34208 (BOL).

8.8. Restio subgen. Locapsis H.P.Linder \& C.R. Hardy, subgen. nov., a subgeneribus ad Restio ascriptis combinatione epidermidis culmorum unistratae, cum vaginis persistentibus, spiculisque maribus erectis, ovarioque indehiscenti, spiculisque femineis fusiformibus, tepalisque chartaceis rotundatis distinguendum.

\section{TYPE.-Restio vimineus Rottb.}

Plants mostly tufted, occasionally tending to mat-forming from spreading underground stolons. Fertile culms mostly branching, round; sheaths persistent, closely or loosely convoluted or often flat and standing free from culm, margins generally same texture as body of sheath, without membranous upper margin or membranous shoulders. Male and female inflorescences similar, racemose or paniculate, with up to 20 erect spikelets; spathes persistent, very rarely overtopping spikelets; bracts concolorous, margins same texture and colour as body of bract, usually cartilaginous, as tall as or somewhat taller than flowers. Male flowers with exserted anthers. Female spikelet generally narrowly elliptical, with up to 12 flowers, as flowers mature bracts usually diverge, transforming spikelet from slender to bristly. Female flowers laterally compressed; female tepals chartaceous and apically rounded, keels of lateral sepals generally \pm villous; staminodes present or absent. Gynoecium with 3, feathery, white to red styles free to base or seated on a stylopodium; ovary unilocular, indehiscent. Diaspores small, soft nuts, perianth persistent and \pm enclosing nuts. Culm anatomy: epidermal cells in 1 layer, lateral walls straight and unthickened or sinuose and thickened; parenchyma (1)2(3) cells wide; central ground tissue with a single central cavity (this lacking in $R$. ramosissimus) tannin usually absent, when present, in epidermis and central ground tissue; silica usually absent, but present in parenchyma of $R$. rigoratus.

\section{Etymology: Locapsis (f.), an anagram of Calopsis.}

Notes: Restio subgen. Locapsis contains the largest fragment of Calopsis sensu Linder (1984). The genus is readily diagnosed by several attributes. The spreading, concolorous sheaths are not found in all species, but are quite unique in the tribe. The narrow, usually manyflowered female spikelets are also distinctive, especially together with the more-or-less papery, rounded tepals. As such, the genus is easy to delimit against its phylogeneti- 
cally closest relatives: Restio s.str. and $R$. subgen. Ischyrolepis (Figure 5). However, it is much more difficult to delimit the genus from Restio subgen. Eremorestio, and morphologically and ecologically it would be much more satisfying to combine these two genera.

\subsubsection{Restio andreaeanus (Pillans) H.P.Linder \&} C.R.Hardy, comb. nov.

Leptocarpus andreaeanus Pillans in Transactions of the Royal Society of South Africa 16: 349 (1928). Calopsis andreaeana (Pillans) H.P.Linder: 465 (1985). Type: Willowmore Aasvogelberg, Andreae 975 (BOL, holo.!; STE!).

8.8.2. Restio tenuispicatus H.P.Linder \& C.R.Har$d y$, nom. nov. pro Hypolaena filiformis Mast. in Journal of the Linnean Society, Botany 10: 267 (1868). Calorophus filiformis (Mast.) Kuntze: 747 (1891). Calopsis filiformis (Mast.) H.P.Linder: 467 (1985). Type: Houw Hoek Mtn, Zeyher 4349 (K, lecto.! [Linder in Bothalia 15: 467 (1985)]; BOL!, BR!, MEL!, P!); s.loc., Thom 1031 (K!), non Restio filiformis Poir.

The name refers to the slender culms, also expressed in the specific epithet filiformis.

8.8.3. Restio calcicola H.P.Linder \& C.R.Hardy, nom. nov. pro Leptocarpus fruticosus Mast. in Botanische Jahrbücher 29, Beiblatt 66: 9 (1900b). Calopsis fruticosa (Mast.) H.P.Linder: 467 (1985). Type: in hills near Ratels River, Schlechter 9718 (K, lecto.! [Linder, Bothalia 15: 467 (1985)]; BM!, BR!, MO!, NBG!, P!, S!, WAG!), Schlechter 9717 (B!, BM!, BR!, K!, MO!, NBG!, P!, S!, WAG!), non Restio fruticosus Thunb. (= Rhodocoma fruticosa (Thunb.) H.P.Linder).

This is a limestone species, hence the specific name.

8.8.4. Restio albotuberculatus H.P.Linder \& C.R. Hardy, nom. nov. pro Leptocarpus burchellii Mast. in Journal of the Linnean Society, Botany 10: 222 (1868). Calopsis burchellii (Mast.) H.P.Linder: 465 (1985). Type: between Vet River and Krombecks River, Burchell 7185 (K, lecto.! [Linder in Bothalia 15: 465 (1985)]; BOL!); foot of Langeberg at Kampsche Berg, Burchell 7146 (BOL!, K!); Malgaten River at Wolf Drift, Burchell 6101 (BOL!, K!), non Restio burchellii Pillans.

Named for the characteristic white tubercles on the culms.

8.8.5. Restio muirii (Pillans) H.P.Linder \& C.R. Hardy, comb. nov.

Leptocarpus muirii Pillans in Transactions of the Royal Society of South Africa 16: 353 (1928). Calopsis muirii (Pillans) H.P.Linder: 469 (1985). Type: north end of Garcia's Pass, Muir 3178, 3179 (BOL, holo.!).

8.8.6. Restio ramosissimus H.P.Linder \& C.R. Hardy, nom. nov. pro Hypolaena gracilis Nees ex Mast. in Journal of the Linnean Society, Botany 10: 266 (1868). Calorophus gracilis (Mast.) Kuntze: 747 (1891). Leptocarpus gracilis (Mast.) Pillans: 146 (1922). Calopsis gracilis (Mast.) H.P.Linder: 467 (1985). Type: Muizenberg, Zeyher 4347 (K, lecto.! [Linder in Bothalia 15: 467 (1985)]; MEL!, P!, S!, Z!); near Simonstown, Zeyher 1006 (K!); Wright 500 (P!), non Restio gracilis R.Br.

8.8.7. Restio rigoratus (Mast.) H.P.Linder \& C.R. Hardy, comb. nov.

Leptocarpus rigoratus Mast. in Botanische Jahrbücher 29, Beiblatt 66: 9 (1900b). Calopsis rigorata (Mast.) H.P.Linder: 470 (1985). Type: in hills near Vogelvlei near Elim, Schlechter 10490 (B, lecto.! [Linder in Bothalia 15: 470 (1985)]; BOL!, K!, MO!, NBG!, P!, S!, WAG!, Z!).

8.8.8. Restio rudolfii (Pillans) H.P.Linder \& C.R. Hardy, nom. nov. pro Leptocarpus marlothii Pillans in Transactions of the Royal Society of South Africa 16: 353 (1928). Calopsis marlothii (Pillans) H.P. Linder: 467 (1985). Type: Vaalkloof, near Karoopoort, Marloth 9102 (BOL, holo.!; B!, K!), non Restio marlothii Pillans.

Named for Rudolf Marloth.

8.8.9. Restio vimineus Rottb., Descriptiones plantarum rariorum 10 (1772).

\subsubsection{Restio adpressus (Esterh.) H.P.Linder \&} C.R.Hardy, comb. nov.

Calopsis adpressa Esterh. in Linder in Bothalia 15: 465 (1985) Type: hills inland from Pearly Beach, Esterhuysen 32977 (BOL, holo.!; E!, K!, L, M!, MO!, S!).

8.8.11. Restio durus (Esterh.) H.P.Linder \& C.R. Hardy, comb. nov.

Calopsis dura Esterh. in Linder in Bothalia 15: 466 (1985). Type: South Cedarberg suurvlakte, between Kaffirkop and Loskop, Esterhuysen 34251 (BOL, holo.!; B!, C!, E!, F, GRA!, K!, L, LD, M!, MO!, NBG!, NY, PRE!, RSA, S!, STE!, TCD!, UC, US, W!, WAG!).

8.9. Restio subgen. Ischyrolepis (Steud.) H.P.Linder \& C.R.Hardy, stat. nov.

Ischyrolepis Steud., Synopsis plantarum glumacearum. 2: 249 (1855). Type: Ischyrolepis subverticellatus Steud. (= Restio subverticellatus (Steud.) Mast.).

Plants tufted or tangled, often with spreading stolons, but very rarely with rhizomes. Fertile culms usually branching, rarely unbranched or branches whorled at nodes; round or very rarely compressed; sheaths persistent, closely or more rarely loosely convoluted, very rarely standing free from culm; margins coriaceous or membranous, sometimes with tall membranous lobes flanking mucro. Male and female inflorescences basically quite similar, racemose to paniculate, 1 to numerous spikelets, except that females generally have fewer and larger spikelets than males; in some species male spikelets tightly clustered, while females tend to have single spikelets. Male spikelets sometimes linear and curved, bracts obtuse to often acuminate and recurved, or extended into a slender awn; anthers exserted from flowers at anthesis. Female spikelets with up to 40 flowers; bracts shorter to taller than flowers, apically obtuse to often acuminate and recurved, or extended into a fine awn; flowers laterally compressed; tepals chartaceous or cartilaginous; glabrous or keels of lateral sepals more or less villous; staminodes absent. Gynoecium with 2, white to red, feathery styles; style bases fused to form a pillar; ovary with 2(1) locules, dehiscent. Seed translucent or variously coloured, smooth, pitted, colliculate, striate or rarely rugose. Culm anatomy: epidermal cells 1-layered, lateral walls straight and unthickened or sinuose and thickened; parenchymatous layer 1-3 cells deep; central ground tissue solid or with a single, central cavity; tannin absent or present in epidermis, sclerenchyma or central ground tissue; silica absent or present in parenchyma and/or rarely in central ground tissue.

Etymology: Ischyrolepis (f.): Ischyros (Greek), strong; lepis (Greek), scale; presumably this refers to the usually quite tough floral scales which enclose the flowers. 


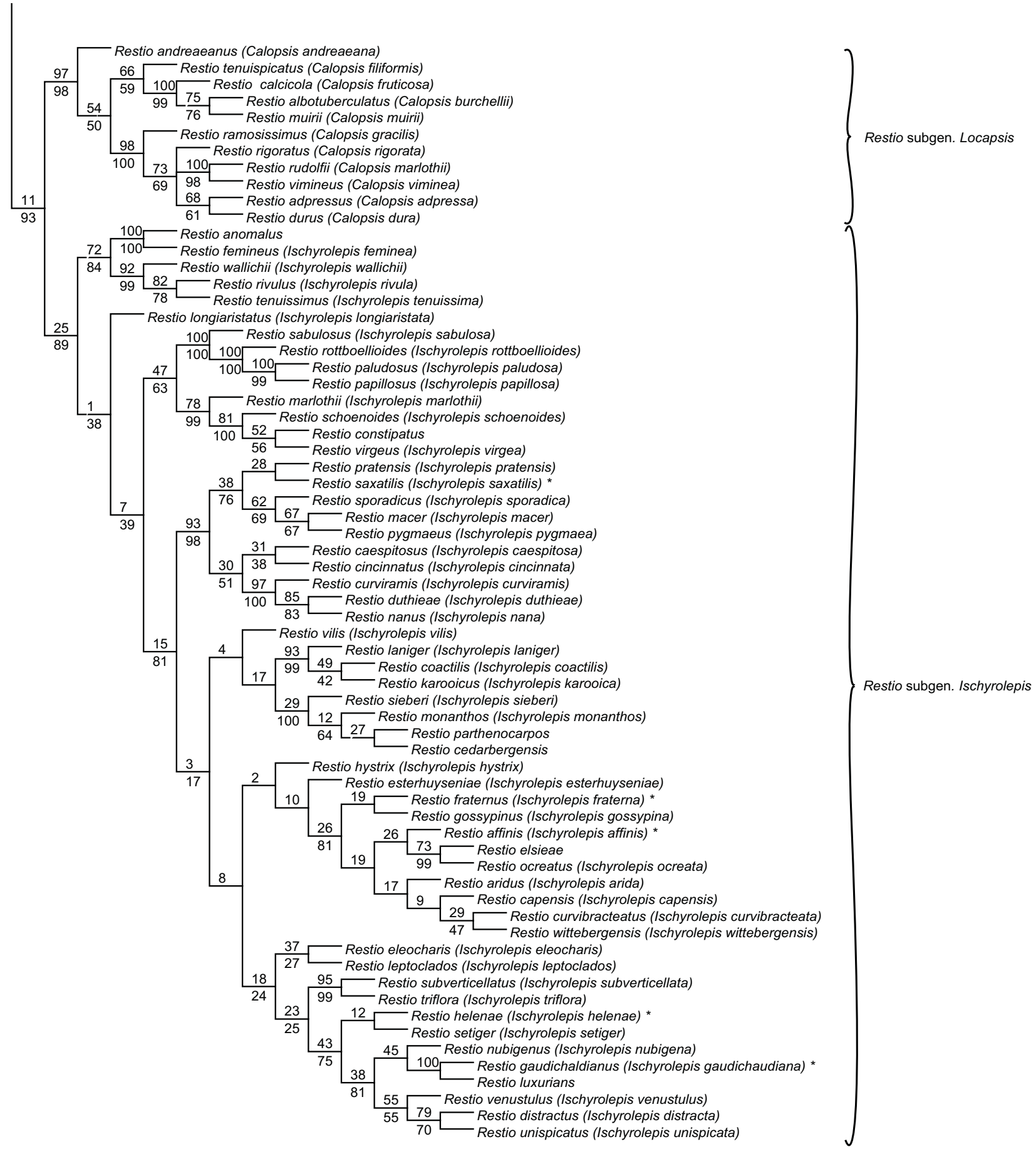

FIGURE 5.-Portion of strict consensus tree of the total combined analysis of Hardy et al. (2008) containing Restio subgen. Locapsis and R. subgen. Ischyrolepis. A single species of Restio subgen. Ischyrolepis (Restio fuscidulus) that was missing many data (including all molecular data), was resolved in this tree as sister to Staberoha (see Figure 1), albeit with $3 \%$ bootstrap support which we do not consider substantial enough to warrant disputing the monophyly of Restio subgen. Ischyrolepis. Names in parentheses are the now synonymous names of Linder (2001a) when different from the ones here proposed. Bootstrap values above branches indicate support based on a 500-replicate bootstrap analysis that included 20 species for which DNA data were lacking (asterisked taxa). Bootstrap values below branches indicate support based upon a 500-replicate analysis that included only taxa for which both DNA data and morphology data were available. Where no value is given below a branch it indicates that the clade did not appear in the analysis excluding morphology-only species.

Notes: Restio subgen. Ischyrolepis is readily diagnosed by a basal stylar peg, formed by the fusion of the two style arms. This persists on the ripe ovary, even after the seed has been released, as a distinctive peg. This is unique in the Restioneae. Furthermore, it usually has two styles (compare to the three or one more typically found). The species can look superficially very similar to Restio s.str. or Restio subgen. Craspedolepis. The pollen type is held in common with Staberoha, but the two genera are not phylogenetically closely related, according to the molecular data.

It is particularly common in the more arid parts of the Greater Cape Floristic Region (Born et al. 2007), and is replaced along the wetter coastal mountains by the subgenera Craspedolepis and Restio. 
There are a number of groups in this large subgenus, but it is not possible to clearly diagnose them. Furthermore, the subgenus, as currently defined, is so easily diagnosed that there is very little sense recognizing smaller groups at subgeneric level. However, further research may indicate that these subgroups deserve sectional recognition.

a) Female spikelets small and mostly with single flowers; styles often red:

8.9.1. Restio anomalus H.P.Linder sp. nov., a $R$. femineus marginibus vaginarum late membranaceis, tepalis interioribus florum feminearum $3.0-4.5 \mathrm{~mm}$ longis, ovario biloculari statim dignoscenda.

TYPE.-Western Cape, 3419 (Caledon): Pheasantshoek near Viljoenshof, in a marshy area near Elegia fistulosa and Restio festucaeformis, and along a small stream (or furrow), in peaty soil and on clayish bank, no male found, (-DA), 15-09-1976, Esterhuysen 34374 (BOL, holo.).

Plants compact, tufted, $0.15-0.25 \mathrm{~m}$ tall. Fertile culms branching, round, solid or with a small central cavity, finely rugulose or finely warty, green or olivaceous, $0.2-$ $0.4 \mathrm{~mm}$ diam. at apex; sheaths several, persistent, closely convoluted, 5-13 mm long, acute, margins entire, variable: greenish/olivaceaous or tan or light to darker brown, always with brown speckles and tan margins, hyaline shoulders absent; mucro penicillate, straight and erect or recurved, 3-7 mm long. Female inflorescence with 2-10 spikelets, interrupted or linear, 5-70 × 3-5 mm; spathes shorter than spikelets, persistent, coriaceous or cartilaginous; spikelet obovate or triangular with fruit sitting at base and tepals flaring apart at top, 4.0-6.5 mm long, with 1 flower, with 0 sterile bracts; bracts shorter than flowers, erect, 2.6-5.0 mm long, oblong, obtuse, cartilaginous, awn minute to less than half as long as bract body. Flower with four tepals; tepals $3.0-4.5 \mathrm{~mm}$ long, undifferentiated, coriaceous or cartilaginous, glabrous and smooth; margins entire, apices acute; staminodes absent; ovary with 2 locules, dehiscent; style 1, flattened. Seed (1.16-)1.27(-1.44) × (0.68-)0.73(-0.8) mm, in side view elliptical, in transverse view round, white, pitted. Flowering time: September.

Distribution and ecology: endemic on the Agulhas plains between Elim, Viljoenshof and the Soetanysberg, at an altitude of $50-150 \mathrm{~m}$, on either sandstone or silcretes. The species is locally common on gravelly soils or damp sand, often with impeded drainage.

Notes: this species is known currently only from the female material, and since it can be very common locally, it is presumably apomictic. It is closely related to Restio femineus, which is also known only from female material, and which forms similar neat little branching tufts. However, $R$. anomalus differs in many details from $R$. femineus. The sheath margins are broadly membranous (instead of coriaceus or narrowly membranous), the spathes overtop the spikelets (instead of being as tall as the spikelets), the inner and outer tepals are the same length (instead of the inner tepals being shorter than the outer tepals), the inner tepals are 3.0-4.5 mm long, compared to $2.2-2.6 \mathrm{~mm}$ in $R$. femineus, and the ovary has two locules instead of one. In addition, there are numerous small anatomical differences in the culm.

Etymology: $a$ - (in Greek composition), not; normalis (Greek), normal; abnormal, referring to the absence of male plants.

\section{Additional collections}

WESTERN CAPE.-3419 (Caledon): along road from Baardskeerdersbos to Elim; on laterite scrape on hill W of Elim. Locally common on damp sand over laterite, probably seasonally waterlogged conditions. Erect, tuft-like plants, only females seen, (-DA), 03-07-1999, Linder 6940 (BOL); Farm 'Brandfontein'; plateau between the sea and Soetanysberg. Table Mountain Sandstone (TMS) with sand overlay. In shallow wet sand on shaved off TMS bedrock, forming small tussocks. No males seen, (-DD), 25-10-1990, Linder 5163 (BOL); Hangnes, base of Soetanysberg; in marsh, near windmill, (-DD), 12-04-1978, Esterhuysen 34894 (BOL).

\subsubsection{Restio femineus (Esterh.) H.P.Linder \& C.R.}

\section{Hardy, comb. nov.}

Ischyrolepis feminea Esterh. in Linder in Bothalia 15: 404 (1985). Type: Simonstown, near the Four Seasons, W of Betty's Bay, Esterhuysen 31662 (BOL, holo.!; C!, E!, K!, L!, M!, MO!, NBG!, PRE!, S!, STE!).

8.9.3. Restio wallichii Mast. in Journal of the Linnean Society, Botany 8: 234 (1865).

8.9.4. Restio rivulus (Esterh.) H.P.Linder \& C.R. Hardy, comb. nov.

Ischyrolepis rivula Esterh. in Linder in Bothalia 15: 413 (1985). Type: Wuppertal, Boboskloof, Esterhuysen 31912 (BOL, holo.!; C!, E!, F!, K!, L!, LD!, M!, MO!, NBG!, PRE!, S!, STE!, TCD!, UC!, US!, W!, WAG!).

8.9.5. Restio tenuissimus Kunth in Enumeratio plantarum 3: 394 (1841).

\subsubsection{Restio longiaristatus (Pillans ex H.P.Linder)} H.P.Linder \& C.R.Hardy, comb. nov.

Ischyrolepis longiaristata Pillans ex H.P.Linder in Bothalia 15: 407 (1985). Type: Van Rhynsdorp, Driekoppen, Gifberg, Esterhuysen 30749 (BOL, holo.!; B!, D!, E!, F!, GRA!, K!, L!, LD!, M!, MO!, NBG!, NY!, PRE!, RSA!, S!, STE!, TCD!, UC!, US!, W!, WAG!).

8.9.7. Restio sabulosus Pillans in Transactions of the Royal Society of South Africa 16: 285 (1928).

8.9.8. Restio rottboellioides Kunth, Enumeratio plantarum 3: 394 (1841).

8.9.9. Restio paludosus Pillans in Annals of the Bolus Herbarium 3,3: 142 (1922).

\subsubsection{Restio papillosus (Esterh.) H.P.Linder \&}

C.R.Hardy, comb. nov.

Ischyrolepis papillosa Esterh. in Linder in Bothalia 15: 410 (1985). Type: Simonstown, Kenilworth Race Course, Esterhuysen 30849 (BOL, holo.!; B!, C!, E!, F!, GRA!, K!, L!, LD!, M!, MO!, NBG!, NY!, PRE!, RSA!, S!, STE!, TCD!, UC!, US!, W!, WAG!).

8.9.11. Restio pratensis (Esterh.) H.P.Linder \& C.R. Hardy, comb. nov.

Ischyrolepis pratensis Esterh. in Linder in Bothalia 15: 411 (1985). Type: Cape Town, Paarl Reserve on Paarl Mountain, Esterhuysen 31206 (BOL, holo.!; C!, E!, F!, K!, L!, M!, MO!, NBG!, S!, STE!, UC!).

8.9.12. Restio macer Kunth, Enumeratio plantarum 3: 390 (1841).

8.9.13. Restio sporadicus (Esterh.) H.P.Linder \& C.R.Hardy, comb. nov.

Ischyrolepis sporadica Esterh. in Linder in Bothalia 15: 413 (1985). Type: Cape Town, Riverlands near Mamre Road, Esterhuysen 34656 (BOL, holo.!; C!, E!, K!, L!, M!, MO!, S!, STE!)

8.9.14. Restio pygmaeus Pillans in Transactions of the Royal Society of South Africa 30: 253 (1945). 
8.9.15. Restio cincinnatus Mast. in Journal of the Linnean Society, Botany 8: 240 (1865).

8.9.16. Restio caespitosus (Esterh.) H.P.Linder \& C.R.Hardy, comb. nov.

Ischyrolepis caespitosa Esterh. in Linder in Bothalia 15: 402 (1985). Type: Caledon, Pheasantshoek near Viljoenshof, Esterhuysen 34358 (BOL, holo.!; B!, C!, E!, F!, GRA!, K!, L!, LD!, M!, MO!, NBG!, NY!, PRE!, RSA!, S!, STE!, TCD!, UC!, US!, W!, WAG!).

\subsubsection{Restio saxatilis (Esterh.) H.P.Linder \&} C.R.Hardy, comb. nov.

Ischyrolepis saxatilis Esterh. in Linder in South African Journal of Botany 56: 456 (1990). Type: Stellenbosch, Dragoon Buttress, Esterhuysen 32360 (BOL, holo.!; K!, M!, MO!, S!).

8.9.18. Restio curviramis Kunth, Enumeratio plantarum 3: 395 (1841).

8.9.19. Restio nanus (Esterh.) H.P.Linder \& C.R. Hardy, comb. nov.

Ischyrolepis nana Esterh. in Linder in Bothalia 15: 409 (1985). Type: Worcester, lower Wellington Sneeukop, at W base of the shale band, Esterhuysen 32658 (BOL, holo.!; C!, E!, K!, L!, M!, MO!, S!, STE!).

8.9.20. Restio duthieae Pillans in Transactions of the Royal Society of South Africa 16: 287 (1928).

b) Spikelets larger, usually few, many-flowered:

8.9.21. Restio marlothii Pillans in Annals of the Bolus Herbarium 3,2: 83 (1921).

8.9.22. Restio schoenoides Kunth, Enumeratio plantarum 3: 391 (1841).

8.9.23. Restio constipatus H.P.Linder, sp. nov., a Restio wittebergensi culmis ramosis, a $R$. schoenoide spiculis maribus 3-6 mm longis, spathis femineis spicula aequantibus, seminibus argenteis recedit.

TYPE.-Western Cape, 3319 (Worcester): summit of Matroosberg, among rocks, (-BC), 21-01-2001, H.P.Linder 7139 (Z, holo.; BOL, K, MO, NBG).

Plants clumped or tangled, stoloniferous, forming dense cushions among boulders, $0.2-0.5 \mathrm{~m}$ tall, or spreading mats on open slopes. Fertile culms branching, smooth, green or olivaceous, $0.5-1.5 \mathrm{~mm}$ diam. at apex; sheaths closely convoluted, 10-25 mm long, dark brown, apical margins narrowly membranous, hyaline shoulders absent, apex acute to acuminate; mucro penicillate, straight and erect, 2-10 $\mathrm{mm}$ long. Male inflorescence with 1 spikelet (very rarely, in the Swartberg) or 2-10 spikelets, forming a tight button, $8-25 \times 7-25 \mathrm{~mm}$; spathes persistent, as tall as spikelets, coriaceous, rather similar to lower bracts; male spikelets sessile, oblong or elliptical, 7-12 × 3-6 mm, 310-flowered; bracts taller than flowers, $5.5-10 \mathrm{~mm}$ long, oblong, acuminate, cartilaginous. Male flower 4.5-5.0 mm long, both tepal whorls equally long, hyaline or membranous, linear or oblong, outer lateral tepals conduplicate, sparsely villous on keels; anthers 2-3 mm long, exserted from flowers; pistillode absent. Female inflorescence with 1 spikelet (rarely, then mostly at western and eastern extremes of range) or 2-10 spikelets, forming a tight button, 10-25 × 3-25 mm; spathes equalling spikelets, persistent, coriaceous; spikelets sessile, elliptical, obtuse or acute, 10-20 mm long, 5-15-flowered, with 4 or 5 sterile bracts; bracts taller than flowers, erect or reflexed, 5.5-10 $\mathrm{mm}$ long, oblong, acuminate, cartilaginous, apical margin like rest of bract, same as body of bract, awn less than half as long as bract body. Female flower 5.0-6.5 mm long, tepals cartilaginous, all equally long, outer lateral tepals conduplicate with sparsely villous keels, odd outer and inner tepals oblong; staminodes absent. Gynoecium: styles 2, feathery, white; style bases free but adjacent; ovary dehiscent, bilocular. Seed 1.3-1.5 × $1 \mathrm{~mm}$, in side view elliptical, in diam. round, silvery, pitted. Flowering time: September to December.

Distribution and ecology: widespread on the summits of the inner ranges of the Cape Fold Mountains, from Sneeukop in the Cedarberg to Mannetjiesberg in the Kamannassie and Meiringspoortberg in the Groot Swartberg. The species is absent from the lower coastal mountains: the Kogelberg, Kleinriviersberg and the Cape Peninsula. The altitude range is $1500-2100 \mathrm{~m}$, all collections are from sandstone habitats. This is a species of rocky summits and exposed ridges. On the Matroosberg, the first author found it growing on shady rock ledges, well protected from fire, and quite cool, but dry. This is consistent with most habitat notes, which indicate cool, dry places, associated with rocks or rocky sites, or ledges. Possibly these are all fire-protected habitats.

Notes: the new species is similar to Restio wittebergensis; both species have both male and female spikelets aggregated into button-like heads. However, it differs from $R$. wittebergensis by its branching culms ( $R$. wittebergensis has simple culms), and the stoloniferous habit ( $R$. wittebergensis is caespitose). The stoloniferous habit and aggregated spikelets suggest a similarity to $R$. schoenoides, but this species is more slender, carpet-forming rather than tangled. There is a wide range of variation within $R$. constipatus, and in its current definition it might include two entities: the typical boulder-habitat (rocky summit) plants from the western part of the range, and more mat-forming plants from the Swartberg, which are very common along the summit ridges of these inland mountains. The differences in growth form are corroborated by a subtle difference in the flower size and a more slender growth form. This needs more, critical, investigation. These collections have in the past been assigned to $R$. schoenoides; however, the latter species is better understood as a summer rainfall species widespread in the Drakensberg and reaching to the Blouberg in the Limpopo Province. The interface between $R$. schoenoides and $R$. wittebergensis remains taxonomically difficult.

Etymology: constipata (Latin), crowded together; referring to the male and female spikelets, clustered together in capitate inflorescences. The name does not refer to medicinal use.

\section{Additional collections}

WESTERN CAPE.-3219 (Wuppertal): Cedarberg, kloof above Crystal Pool, (-AC), 25-06-1942, Esterhuysen 7897 (BOL); Cedarberg, peak near Sneeuwkop, (-AC), 02-01-1942, Esterhuysen 7567 (BOL); Cedarberg, Middelberg, SW slopes, (-AC), 01-03-1940, Esterhuysen $2524 b$ (BOL); Cold Bokkeveld, Turret Peak, in a cool shady spot above stream, and at base of rock, in colonies, forming patches, (-CC), 15-10-1972, Esterhuysen 33025 (BOL).

3319 (Worcester): Ceres-Tulbagh, Swartgat Peak, Sneeugat peaks, on steep upper slopes, SE aspect, (-AA), 02-05-1964, Esterhuysen 30687 (BOL); Worcester, Mosterts Hoek Twins, (-AD), 08-01-1944, Esterhuysen 9832 (BOL); Worcester, Mostert's Hoek Twins, S side of summit at base of low rock cap, in solid masses, (-AD), 23-02-1964, 
Esterhuysen 30615 (BOL); Worcester, Ridge Peaks, Waaihoek, summit, $1800 \mathrm{~m}$, amongst rocks, (-AD), 15-12-1942, Esterhuysen 8372 (BOL); Ceres, Roodeberg, (-BC), 01-01-1940, Esterhuysen 1487 (BOL); Worcester-Ceres, Matroosberg, at rocky summit, in shallow soil around base of low rock or along cracks or in stony soil, dense wiry plants, (-BC), 10-10-1962, Esterhuysen 29728 (BOL); Worcester, Roodeberg, Matroosberg group, on upper rocky slopes, often along step ledges, at the base of rock, dense growth, (-BC), 05-04-1964; Esterhuysen 30677 (BOL); Worcester, Matroosberg, on upper rocky slopes, along the base of low rock, dense masses, (-BC), 08-04-1980, Ester huysen 35419a (BOL); Ceres, Roodeberg, (-BC), 01-01-1940, Esterhuysen 1487 (BOL); Worcester, Pulpit Rock Nek, Hex River Mtns, in cracks in rock pavement ledges, (-BC), 09-03-1963, Esterhuysen 30076 (BOL); Worcester, Upper Wellington Sneeukop, N aspect, steep, rocky, well-drained slope, (-CA), 04-10-1964, Esterhuysen 30779a (BOL); Worcester, Du Toit's Peak, on rocky upper slopes and summit plateau, in dense masses, (-CA), 21-12-1975, Esterhuysen 34164 (BOL); Worcester, Du Toit's Peak, on rocky summit and upper rocky slopes and ridges, $\mathrm{S}$ aspect, varying in height, (-CA), 01-12-1963, Esterhuysen 30561 (BOL); Worcester, Du Toit's Peak, (-CA), 26-011943, Esterhuysen 8558 (BOL); Worcester, Witteberg, on rocky slopes near summit, (-CA), 28-02-1965, Esterhuysen 30957 (BOL); Worcester, Upper Wellington Sneeukop, growing against or next to rock, not seen on the smoother slopes, (- CA), 23-01-1972, Esterhuysen 32798 (BOL); Worcester, Slanghoek Peak, (- CA), 28-12-1975, Esterhuysen s.n. (BOL); Worcester, Slanghoek Peak, on shale band on S side, (-CA), 31-12-1972, Esterhuysen 33070a (BOL); Worcester, Slanghoek Mtns, ridge S of Grassy Dome, (-CA), 05-06-1966, Esterhuysen 31556 (BOL); Worcester, Du Toit's Peak, at rocky summit, growing between low rock, (-CA), 25-11-1962, Esterhuysen 29892 (BOL); Worcester, Witteberg, above Du Toit's Kloof, on summit, growing from between rock and in shallow marshy soil, (-CA), 04-08-1963, Esterhuysen 30253 (BOL); Worcester, Brandwacht Peak, near summit growing between rock surfaces or from crevices on W side, growing densely, (-CB), 07-04-1963, Esterhuysen 30124; Worcester, Waaihoek Peak, on SSE side of rocky summit, and amongst rocks near summit, common in patches, (-CB), 05-06-1965, Esterhuysen 31063 (BOL); Kaffir Kop, between Paardekop and Adolph's Kop, Fransch Hoek Pass, Villiersdorp, on sloping sandstone pavement, S aspect, (-CC) 02-11-1969, Esterhuysen 32309a (BOL); Caledon, Olifantsberg area near Genadendal, Boscheveld, rocky, summits, (-CD), 02 Jan. 1965 Esterhuysen 30895 (BOL); Soutrivier, Koo Rd, $\pm 14 \mathrm{mls}[22.4 \mathrm{~km}] \mathrm{S}$ of Matroosberg Station, in Protea mellifera veld, (-DB), 09-02-1964, Jessop s.n. (BOL).

3321 (Ladismith): Ladismith, Toverkop, Swartberg, on upper slopes, (-AC), 02-09-1973, Esterhuysen 33231 (BOL); Ladismith, Toverkop, Swartberg, on ledges and rocky places, $\mathrm{N}$ or roughly $\mathrm{N}$ aspect, common in patches, (-AC), 30-03-1964, Esterhuysen 30671 (BOL); Ladismith, from Toverkop to Seven Weeks Poort Berg, common on upper rocky slopes, (-AC), 30-03-1959, Esterhuysen 28269 (BOL); Prince Albert, Seven Weeks Poort Mtns, (-AD), 01-12-1928, Stokoe s.n. (BOL); Ladismith, Swartberg, Kouveldberg, (-AD), 30-031964, Esterhuysen 30666a (BOL); Ladismith, Seven Weeks Poort Berg to Toverkop, Swartberg, very common on upper slopes forming dense stands or pure communities in places, in stony, rocky places, on ledges, 1.0-1.5 ft [0.3-0.5 m] tall, (-AD), 27-03-1964, Esterhuysen 30656 (BOL); Ladismith, Seven Weeks Poort Berg, common on upper slopes, $\mathrm{N}$ north side and summit, (-AD), 01-04-1975, Esterhuysen 33798 (BOL); Calitzdorp, Gamka Reserve, Snygans-Bakens Kop area, at base of small cliff, $\mathrm{S}$ aspect, below hilltop, and between rock on top of cliff, (-BC), 22-05-1975, Esterhuysen 33834 (BOL).

3322 (Oudtshoorn): Prince Albert, Swartberg, (-AC), 01-10-1949, Stokoe in SAM74945 (BOL); Prince Albert, Swartberg, (-AC), 01-101949, Stokoe in SAM74944 (BOL); Prince Albert, Tierberg area, Swartberg, N slopes, (-AD), 01-06-1962, Esterhuysen 29549 (BOL); Oudtshoorn, Meiringspoortberg, on S slopes near summit and on $\mathrm{N}$ side on small vlakte, (-BC), 09-04-1966, Esterhuysen 31494 (BOL); Uniondale Mannetjiesberg, S slopes, (-DB), 05-11-1941, Esterhuysen 6403 (BOL).

\subsubsection{Restio virgeus Mast. in Botanische Jahrbücher} 29, Beiblatt 66: 4 (1900b).

8.9.25. Restio curvibracteatus (Esterh.) H.P.Linder \& C.R.Hardy, comb. nov.

Ischyrolepis curvibracteata Esterh. in Linder in Bothalia 15: 403 (1985). Type: Worcester, Du Toit's Peak, Esterhuysen 29894 (BOL, holo.!; B!, C!, E!, F!, K!, L!, M!, MO!, S!, STE!, UC!).
8.9.26. Restio wittebergensis (Esterh.) H.P.Linder \& C.R.Hardy, comb. nov.

Ischyrolepis wittebergensis Esterh. in Linder in Bothalia 15: 417 (1985). Type: Montagu, upper rocky S slopes of Witteberge, Esterhuysen 30479 (BOL, holo.!; C!, E!, F!, K!, L!, LD!, M!, MO!, NBG!, S!, STE!, UC!, WAG!).

8.9.27. Restio setiger Kunth, Enumeratio plantarum 3: 385 (1841).

8.9.28. Restio vilis Kunth, Enumeratio plantarum 3: 389 (1841).

8.9.29. Restio coactilis Mast. in Botanische Jahrbücher 29, Beiblatt 66: 3 (1900b).

\subsubsection{Restiokarooicus(Esterh.)H.P.Linder \& C.R.}

\section{Hardy, comb. nov.}

Ischyrolepis karooica Esterh. in Linder in Bothalia 15: 406 (1985) Type: Worcester, Karoopoort, on mountain slopes above the poort, Esterhuysen 30458 (BOL, holo.!; BM!, C!, E!, F!, GRA!, K!, L!, LD!, M!, MO!, NBG!, NY!, PRE!, RSA!, S!, STE!, TCD!, UC!, US!, W!, WAG!).

8.9.31. Restio hystrix Mast. in Journal of the Linnean Society, Botany 10: 276 (1868).

8.9.32. Restio esterhuyseniae Pillans in Transactions of the Royal Society of South Africa 30: 248 (1945).

8.9.33. Restio gossypinus Mast. in Botanische Jahrbücher 29, Beiblatt 66: 3 (1900b).

\subsubsection{Restio affinis (Esterh.) H.P.Linder \& C.R.} Hardy, comb. nov.

Ischyrolepis affinis Esterh. in Linder in Bothalia 15: 401 (1985). Type: Montagu, Langeberg, Kruispad Ridge between Goedgeloof Peak and Protea Valley, Esterhuysen 35612 (BOL, holo.!; B!, C!, E!, F!, K!, L!, LD!, M!, MO!, NBG!, PRE!, S!, STE!, TCD!, UC!, US!, W!, WAG!).

8.9.35. Restio ocreatus Kunth, Enumeratio plantarum 3: 385 (1841).

8.9.36. Restio fraternus Kunth, Enumeratio plantarum 3: 386 (1841).

8.9.37. Restio elsieae H.P.Linder, sp. nov., R. ocreatae affinis, sed culmis simplicibus, spiculis femineis ellipticis vel ovatis, seminibus longioribus $(2.2-2.8 \mathrm{~mm})$ notabilis.

TYPE.-Western Cape, 3319 (Worcester): Waaihoek Mtns, between Zebasberg and Mt Superior, alt. $1600 \mathrm{~m}$, (-AD), 17-03-2002, H.P.Linder 7460 (Z, holo.; B, BOL, $\mathrm{K}, \mathrm{MO}, \mathrm{NBG}, \mathrm{NSW}, \mathrm{PRE})$.

Plants tufted, 0.16-0.45 m tall, without spreading rhizomes or stolons. Fertile culms unbranched, round, solid or with a small central cavity, smooth, olivaceous, 1.2$2.0 \mathrm{~mm}$ diam. at apex; sheaths several, persistent, loosely convoluted, 18-36 mm long, orange to reddish brown, apical margins narrowly to broadly membranous, acute to acuminate, hyaline shoulders continuing behind mucro; mucro hair-like, straight and erect or recurved or twisted, 3-8 mm long. Male inflorescence racemose or globose, 15-35 × 9-20 mm wide, with 2-10 spikelets; spathes persistent, at least as tall as spikelets, coriaceous or cartilaginous; spikelets erect, elliptical, 7-13 × 2.8-4 mm, 1040-flowered; bracts longer than flowers, 5-11 mm long, widely oblong, acuminate, coriaceous, bract with upper margin membranous, awn recurved, acuminate, at least half as long as the bract body. Male flower 4.5-6.0 mm long; tepals equally long, oblong to elliptical, outer tepals more rigid than inner tepals, outer lateral tepals conduplicate and sparsely to densely villous on keels; anthers 1.8- 
$3.0 \mathrm{~mm}$ long, exserted from flowers; pistillode absent. Female inflorescence with 1 spikelet; spathes up to as long as spikelet, persistent, coriaceous or cartilaginous; spikelet elliptical or ovate, 14-23 mm long, 10-30-flowered; bracts longer than flowers, reflexed, 8-14 mm long, ovate, acute or acuminate, coriaceous, awn up to as long as bract body. Female flower 5-7 mm long, tepals cartilaginous; outer lateral tepals conduplicate, villous along keels, 5-7 mm long; odd outer tepal oblong or ovate, 5$7 \mathrm{~mm}$ long; inner tepals ovate, 4.0-6.5 mm long; staminodes absent. Gynoecium: styles 2, feathery, style bases fused to form a pillar; ovary dehiscent, bilocular. Seed $(2.24-) 2.47(-2.76) \times(1.3-) 1.43(-1.53) \mathrm{mm}$, in side view elliptical, diam. round, silvery or white (and shiny), pitted. Flowering time: January and February; seed release in March and April.

Distribution and ecology: endemic in the Hex River Mountains between Worcester and Ceres, where it is locally very common between $1600-2100 \mathrm{~m}$. It is found on stony, well-drained mountain slopes. It appears to occupy the same habitat as Restio virgeus, and the two species alternate on the stony slopes between Zebasberg and Mt Superior. The plants appear to be killed by fire, regenerating from seed.

Notes: Restio elsieae species is a high-altitude segregate from $R$. ocreata. It differs by the simple, stout culms, and smaller growth form. The single female spikelet with recurved bracts and the unbranched culms are similar to $R$. curvibracteatus, but $R$. elsieae can immediately be recognized by the flat, spreading sheaths.

Etymology: the species is named for Elsie E. Esterhuysen, the foremost collector from the Cape mountains, who made Restionaceae her speciality. She collected actively from 1930 to 1990 , and contributed more to our knowledge of the Cape flora than any other collector. Her meticulous collections, assembled to reflect the distribution range and morphological variability of each species, are currently housed at the Bolus Herbarium, but duplicates of her collections are widely distributed.

\section{Additional collections}

WESTERN CAPE.-3319 (Worcester): Brandwacht Peak, rocky slopes SW-S aspect, below beacon and at base of summit cap, clumps, forming dense pure stands in places, erect, stiffly rounded, seed shed, (-CB), 07-04-1963, Esterhuysen 30123 (BOL); Worcester, Fonteintjiesberg, rocky places on E slopes of ridge below plateau, local, stiff habit, dense rounded clumps, stems pointing in all directions, (-CB), 20-101963, Esterhuysen 30423 (BOL); Worcester, Fonteintjiesberg, above Pulpit Rock Nek, rocky plateau, N and S aspects and steep slope, (-CB), 16-12-1963, Esterhuysen 30588 (BOL); Ceres, Buffelshoek Peak, leading into Witels, shale band, SW aspect, (-AD), 08-10-1956, Esterhuysen 26361 (BOL); Ceres, Milner Peak, Hex River Mtns, rocky W slopes, (-AD), 11-11-1960, Esterhuysen 28606 (BOL); Worcester, Waaihoek Peak, upper rocky slopes, abundant in patches of almost pure stands, dense, scratchy tufts, stems unbranched, (-AD), 11-02-1964, Ester huysen 30612 (BOL); Worcester, Buffelshoek Peak and Buffelshoek Twins, rocky places, (-AD), 19-09-1965, Esterhuysen 31183 (BOL).

8.9.38. Restio cedarbergensis H.P.Linder, sp. nov., a $R$. ocreatae culmis gracilioribus, bracteis maribus brevioribus (3.5-5.0 mm longis), floribus maribus brevioribus (2.5-3.0 $\mathrm{mm}$ longis), spiculis femineis brevioribus (5-11 mm longis), floribus spiculis femineis paucibus (3-8 floribus), seminibus laevibus differt.
TYPE.-Western Cape, 3219 (Wuppertal): Central Cedarberg, Gabriel's Pass directly above De Rif, 1300 m, (-AC), 30-09-2000, H.P.Linder 7090 (Z, holo.; BOL, $\mathrm{K}, \mathrm{MO}, \mathrm{NBG}, \mathrm{PRE})$.

Plants tufted, 0.3-0.6 m tall, without spreading rhizomes or stolons. Fertile culms branching, round, smooth to roughly warty, green or olivaceous, slender, $0.2-0.5$ mm diam. at apex; sheaths loosely convoluted or flat and standing free from culm, 8-20 mm long, golden brown to yellow, acuminate, apical margins narrowly membranous, hyaline shoulders absent; mucro absent or awl- or needleshaped, straight and erect, 0.5-3.0 mm long. Male inflorescence with 6-20 spikelets, racemose or paniculate, 20-55 × 6-12 mm; spathes persistent, at most as tall as spikelets, cartilaginous, acuminate; spikelets pendulous on flexible pedicels, linear or ovate, acute, $6-12 \times 2-3$ $\mathrm{mm}, 4-15$-flowered; bracts equalling flowers, 3.5-5.0 $\mathrm{mm}$ long, ovate, acuminate, cartilaginous, awn minute or at least less than half as long as bract body, acuminate recurved apices give spikelet a bristly appearance. Male flowers 2.5-3.0 mm long; tepals all equally long, linear to oblong; outer tepals cartilaginous, laterals conduplicate and sparsely villous on keels; inner tepals chartaceous; anthers 1.5-2.0 mm long, exserted from flowers; pistillode absent. Female inflorescence with up to 5 spikelets, sparsely paniculate, 5-35 × 4-8 $\mathrm{mm}$; spathes up to as long as spikelets, persistent, cartilaginous; spikelets sessile, elliptical or obovate, rounded, obtuse or acute, 5-11 $\mathrm{mm}$ long, 3-8-flowered; bracts 4.5-6.0 $\mathrm{mm}$ long, ovate, apiculate, bony or coriaceous, awn less than half as long as bract body. Female flower $3.0-4.5 \mathrm{~mm}$ long; tepals all equally long, $2.5-4.5 \mathrm{~mm}$ long, ovate, acute, bony or coriaceous, outer lateral tepals conduplicate with densely villous keels; staminodes absent. Gynoecium: styles 2, feathery, bases fused to form a pillar; ovary dehiscent, bilocular. Seed 1.7-2 × 1.1-1.3 mm, side view oblong (but distinctly bulged at one end), cross section triangular (with corners very rounded), grey (often with brown mottling), smooth. Flowering time: April.

Distribution and ecology: this new species is restricted to the southern Cedarberg and the northern Bokkeveld, and has been collected from Bloukop, north of the Bokkeveld Sneeukop, to Gabriel's Pass in the central Cedarberg. In this region, Restio cedarbergensis is found from 900-1500 m, on well-drained soils, often described as rocky. Several collections are from shale bands, and the first author has seen the species grow next to renosterveld, where sandstone meets shale, as well as on typical dry TMS soils. The species appears to prefer hot, dry, well-drained localities. Plants appear to be killed by fire, regenerating from seed.

Notes: Restio cedarbergensis was previously included under $R$. ocreatus, but it differs by the slender culms, and much smaller spikelets. On Gabriel's Pass the two species co-occur, without intermediates. The new species has finer culms and smaller spikelets, and forms lower, more tangled plants, whereas $R$. ocreatus is much stouter, with larger spikelets. Curiously, the molecular phylogeny does not indicate the relationship to $R$. ocreatus, but suggests a relationship to the $R$. sieberi group, which appears to be unlikely on the basis of the morphological data. 
Etymology: the name indicates the distribution range of the species, from the Cedarberg.

\section{Additional collections}

WESTERN CAPE.-3219 (Wuppertal): Cedarberg, WolfbergTafelberg area, in rocky places, common (-AC), 28-12-1962, Esterhuysen 30008 (BOL); S Cedarberg, (-AC), 01-04-1947, Stokoe 9570 (BOL); S Cedarberg, Dwarsrivierberg, rocky slope, (-CA), 01 Apr 1956, Esterhuysen 25548 (BOL); S Cedarberg, on E spur of Hondverbrand Ridge, sandy vlakte [flats], (-CB), 21-04-1946, Esterhuysen 12719 (BOL); S Cedarberg, Sandfontein Peak, between rocks, (-CB) 05-04-1947, Esterhuysen 13871 (BOL); S Cedarberg, Sandfontein Peak, on rocky sandy W slopes, frequent, (-CB), 20-04-1957, Esterhuysen 27213 (BOL); S Cedarberg, between Sandfontein Peak and Gideon's Kop, on lower stony W slopes, (-CB), 18-04-1965, Esterhuysen 31024 (BOL); N Cold Bokkeveld, Bloukop, on shale band slopes, locally very common, not seen along rocky sandstone ridge, (-CB), 07-07-1968, Esterhuysen 31971 (BOL).

8.9.39. Restio fuscidulus Pillans in Transactions of the Royal Society of South Africa 30: 249 (1945).

8.9.40. Restio aridus Pillans in Annals of the Bolus Herbarium 3,2: 84 (1921).

8.9.41. Restio capensis (L.) H.P.Linder \& C.R.Har$d y$, comb. nov.

Schoenus capensis L., Amoenitates 4: 264 (1755). Restio dichotomus L.: 735 (1767), nom. illeg. Thamnochortus dichtomus (L.) Spreng.: 187 (1824), nom. illeg. Ischyrolepis capensis (L.) Linder: 402 (1985). Type: Cape, s.loc., in Herb. Linn. 1164.3 (LINN holo.)

8.9.42. Restio eleocharis Mast. in Journal of the Linnean Society, Botany 8: 238 (1865).

8.9.43. Restio leptoclados Mast. in Journal of the Linnean Society, Botany 8 (1865).

8.9.44. Restio subverticellatus (Steud.) Mast. in Journal of the Linnean Society, Botany 8: 227 (1865)

8.9.45. Restio triflora Rottb., Descriptiones plantarum rariorum 10 (1772).

8.9.46. Restio helenae Mast. in Journal of the Linnean Society, Botany 8: 233 (1865)

8.9.47. Restio sieberi Kunth, Enumeratio plantarum 3: 387 (1841).

8.9.48. Restio monanthos Mast. in Journal of the Linnean Society, Botany 8: 238 (1865).

8.9.49. Restio parthenocarpos H.P. Linder sp. nov., a $R$. sieberi spiculis femineis floribus 2 vel 3 , bracteis femineis acutis, stylis roseis, a $R$. monanthe spiculis femineis $10-15 \mathrm{~mm}$ longis, bracteis femineis 10-13 mm longis, tepalis 5.0-5.5 mm longis, ab ambabus culmis parce ramificantibus, basi styli pubescenti recedit.

TYPE.-Western Cape, 3219 (Wuppertal): Northern Bokkeveld at start of pass to Suurvlakte, (-CA), 13-092002, H.P.Linder 7509 (Z, holo.; BOL, K, MO, NBG, NSW, PRE).

Plants tufted, compact, $0.25-0.4 \mathrm{~m}$ tall, without spreading rhizomes or stolons, all plants female. Fertile culms sparsely branched, round, smooth, olivaceous, finely warty or finely rugulose, $0.7-0.9 \mathrm{~mm}$ diam. at apex; sheaths several, persistent, closely convoluted, brown, acute, 13-20 $\mathrm{mm}$ long, hyaline shoulders absent, mucro awl- or needleshaped, straight and erect, 3-8 $\mathrm{mm}$ long. Female inflorescence with up to 5 spikelets, racemose or spicate, 10-35 $\times$ 3-10 mm; spathes like floral bracts, persistent, coriaceous; spikelets sessile, oblong, elliptical or ovate, rounded to acute, 10-15 mm long, 2-3-flowered; bracts overtopping flowers, ovate, 10-13 mm long, acute, coriaceous or cartilaginous, imbricate and obscuring spikelet axis; bract awn less than half as long as bract body. Female flower 5-6 mm long; tepals coriaceous or chartaceous, apices acute to acuminate; outer lateral tepals $5.0-5.5 \mathrm{~mm}$ long, conduplicate with keels densely villous; odd outer tepal ovate, 4.0-4.5 mm long; inner tepals shorter than outer, ovate, $3 \mathrm{~mm}$ long; staminodes absent; styles 2, feathery, pink or red, with villous bases fused to form a pillar; ovary dehiscent, bilocular. Seed 1.9-2.1 × 1.2-1.3 mm, in side view oblong, in cross section round or elliptical, silvery, pitted. Flowering time: September and October.

Distribution and ecology: this new, apparently apomictic species is known from only two localities in the Cold Bokkeveld, from the Suurvlakte at the northern end of the Cold Bokkeveld, and from the summit of the Skurweberg Pass at the southern end of the Cold Bokkeveld. The two locations are at 750-1 $100 \mathrm{~m}$, on sandstone, in deep sand over groundwater. Both locations showed some disturbance; the Skurweberg Pass population showed substantial disturbance.

Notes: the affinities of Restio parthenocarpos are not clear, but it may be related to Restio sieberi and $R$. monanthos by the seed surface morphology, seed shape, and general spikelet construction. It may also be of hybrid origin. The molecular phylogeny indicates an affinity to $R$. sieberi, $R$. monanthos and $R$. cedarbergensis. It differs from all species to which it might be assigned by numerous minor characters. The complex of variation associated with $R$. sieberi has not been critically explored, and this possibly apomictic species appears to be well embedded within this variation.

Etymology: parthenocarpos (Greek), producing seed or fruit without fertilization; the specific epithet is a noun in apposition.

\section{Additional collection}

WESTERN CAPE-3319 (Worcester): Agterwitzenberg Pass at dam on pass summit, (-AB), 14-09-2002, Linder, Hardy \& Moline 7523 (BOL, E, K, MO, NBG, NSW, PRE, Z)

\subsubsection{Restio nubigenus (Esterh.) H.P.Linder \& C.R.}

Hardy, comb. nov.

Ischyrolepis nubigena Esterh. in Linder in Bothalia 15: 409 (1985). Type: Worcester, Matroosberg, Esterhuysen 27780 (BOL, holo.!; E!, K!, L!, M!, MO!, S!, STE!).

8.9.51. Restio gaudichaudianus Kunth, Enumeratio plantarum 3: 387 (1841).

\subsubsection{Restio luxurians (Pillans) H.P.Linder, comb.} et stat. nov.

Restio gaudichaudianus Kunth var. luxurians Pillans in Transactions of the Royal Society of South Africa 16: 280 (1928). Type: Glen Leith, foot of the Lange Berge (?), Muir 3078 (BOL, lecto.! [Linder in Bothalia 15: 405 (1985)]; K!); Worcester, Hex River Mountains, Bolus 4234, 4235 (BOL!, K!); Bolus 15949, 15950 (BOL!); Wilde Paarde Berg (?), Stokoe in BOL17665 (BOL!); Montagu, Langeberge at Montagu, Marloth 3118, 3119 (BOL!); Page in BOL16540 (BOL!); Mitchell in BOL16626 (BOL!); Ladismith, Zwarteberge, Marloth 3170 (BOL!); Willowmore, Aasvogelberg, Andreae 940 (BOL!); s.loc., Zwartwaterpoort, Burchell 3409 (BOL!, K!)

Notes: since this form can always and readily be distinguished from Restio gaudichaudianus, it is best recognized at specific level. 
8.9.53. Restio venustulus Kunth, Enumeratio plantarum 3: 388 (1841).

Notes: although the spikelet structure is very similar to the hyper-variable (and probably too broadly defined) species Restio sieberi, the plants can always be distinguished by growth form, by the woolly prophylls, and by the stouter culms and somewhat larger spikelets. Ecologically it is also distinct, and is always associated with large rocks, or even more commonly with passages through the sandstone bedrock, where it often forms large monospecific stands. These habitats are presumably more shaded and colder than the typically sunny open habitat of the numerous forms of $R$. sieberi.

8.9.54. Restio laniger Kunth, Enumeratio plantarum 3: 386 (1841).

8.9.55. Restio distractus Mast., Flora capensis 7: 70 (1897).

8.9.56. Restio unispicatus (H.P.Linder) H.P.Linder \& C.R.Hardy, comb. nov.

Ischyrolepis unispicata H.P.Linder in Bothalia 15: 415 (1985). Type: Wuppertal, Northern Cold Bokkeveld, Vredelus at E base of Schoongezicht Peak, Esterhuysen 29670 (BOL, holo.!; C!, E!, K!, L!, M!, MO!, $\mathrm{S} !)$.

\section{ACKNOWLEDGEMENTS}

This study was funded by the Swiss Science Foundation grant SNF 31-66594-01, and the field work was supported by the Claraz Foundation and National Geographic Society Grant 7289-02. CapeNature provided collecting permission. We particularly want to thank Philip Moline (field work, collaboration on the Elegia complex), the Bolus Herbarium and Terry Trinder-Smith for handling our collections in Cape Town. Peter Goldblatt, Barbara Briggs and Nick Helme are thanked for critical input into the paper, and Peter Wilson and Otto Leistner for checking the Latin.

\section{REFERENCES}

ADAMSON, R.S. \& SALTER, T.M. 1950. Flora of the Cape Peninsula. Juta, Cape Town.

BACKLUND, A. \& BREMER, K. 1998. To be or not to be-principles of classification and monotypic plant families. Taxon 47: 391-400.

BENTHAM, G. \& HOOKER, J.D. 1862-1883. Genera plantarum. Reeve, London.

BERGIUS, P.J. 1767. Descriptiones plantarum ex Capite Bonae Spei. Stockholm.

BORN, J., LINDER, H.P. \& DESMET, P. 2007. The Greater Cape Floristic Region. Journal of Biogeography 34: 147-162.

BRIGGS, B.G. \& LINDER, H.P. 2009. A new subfamilial and tribal classification of Restionaceae (Poales). Telopea 12: 333-345.

BROWN, N.E. 1900. Addenda and corrigenda. In W.T. Thiselon-Dyer, Flora capensis 7: 751-765. Reeve, London.

BROWN, N.E. 1901. Restiaceae. In W.T. Thiselon-Dyer, Flora of tropical Africa 8: 264-266. Reeve, London.

BYTEBIER, B., BELLSTEDT, D.U. \& LINDER, H.P. 2007. A molecular phylogeny for the large African orchid genus Disa. Molecular Phylogenetics and Evolution 43: 75-90.

BYTEBIER, B., BELLSTEDT, D.U. \& LINDER, H.P. 2008. A new phylogeny-based sectional classification for the large African orchid genus Disa. Taxon 57: 1233-1251.

CHANDA, S. 1966. On the pollen morphology of the Centrolepidaceae, Restionaceae and Flagellariaceae, with special reference to taxonomy. Grana Palynologica 6: 355-415.

CHANDA, S. \& ROWLEY, J. 1967. Apertural types in pollen of the Restionaceae and Flagellariaceae. Grana Palynologica 7: 16-36.
CHERMEZON, H. 1930. Sur une variété nouvelle du Restio madagascariensis. Archives de botanique, bulletin mensuel, Caen 4: 84, 85.

CUTLER, D.F. 1969. Juncales. In C.R. Metcalfe, Anatomy of the monocotyledons, vol. 4: 1-357. Clarendon Press, Oxford.

DESVAUX, N.A. 1828. Observationes sur quelque families des plantes monocotylédones, d'aprés les manuscripts de feu le Baron Palisot de Beauvois. Annales des Sciences Naturelles 1,13: 37-52.

DOYLE, J.J. 1992. Gene trees and species trees: molecular studies as one-character taxonomy. Systematic Botany 17: 144-163.

DURAND, T.A. \& SCHINZ, H. 1895-1898. Conspectus florae africae. Bruxelles,

DYER, R.A. 1976. The genera of southern African flowering plants, vol. 2, gymnosperms and monocotyledons. Department of Agricultural Technical Services, Pretoria.

ELDENÄS, P. \& LINDER, H.P. 2000. Congruence and complementarity of morphological and trnL-F sequence, and the phylogeny of the African Restionaceae. Systematic Botany 25: 692-707.

FELSENSTEIN, J. 1978. Cases in which parsimony or compatibility methods will be positively misleading. Systematic Zoology 27: 401-410.

GILG-BENEDICT, C. 1930. Restionaceae. In A. Engler, Die Natürlichen Pflanzenfamilien 15a: 8-27. Engelman, Leipzig.

GILG, E. 1891. Beiträge zur vergleichende Anatomie der xerophilen Familie der Restionaceae. Botanische Jahrbücher 13: 541-606.

GOLDBLATT, P. 1978. An analysis of the flora of southern Africa: its characteristics, relationships, and origins. Annals of the Missouri Botanical Garden 65: 369-436.

HARBORNE, J.B. 1979. Correlations between flavonoid chemistry, anatomy and geography in the Restionaceae. Phytochemistry 18: 1323-1327

HARBORNE, J.B., BOARDLEY, M. \& LINDER, H.P. 1985. Variations in flavonoid patterns within the genus Chondropetalum (Restionaceae). Phytochemistry 24: 273-278.

HARBORNE, J.B. \& CLIFFORD, H.T. 1969. Flavonoid patterns of the Restionaceae. Gossypetin in Restio and a new flavone in Hypolaena. Phytochemistry 8: 2071-2075.

HARDY, C.R. \& LINDER, H.P. 2007. Phylogeny and historical ecology of Rhodocoma (Restionaceae) from the Cape Floristic Region. Aliso 23: 213-226.

HARDY, C.R., MOLINE, P.M. \& LINDER, H.P. 2008. A phylogeny for the African Restionaceae, and new perspectives on morphology's role in generating complete species-level phylogenies for large clades. International Journal of Plant Science 169: 377-390.

HUMPHREYS, A.M. \& LINDER, H.P. 2009. Concept versus data in the delimitation of plant genera. Taxon 33: 1054-1074.

KRAUSS, F. 1845. Pflanzen des Kap- und Natal-Landes, gesammelt und zusammengestellt von Dr Ferdinand Krauss. Flora 28: 337-344.

KUNTH, C.S. 1841. Enumeratio Plantarum, vol. 3. Cottae, Stuttgart \& Tuebingen.

KUNTZE, O. 1891. Revisio generum plantarum, vol. 2,2. Wishoff, Lugduni Batavorum.

LINDER, H.P. 1984. A phylogenetic classification of the genera of the African Restionaceae. Bothalia 15: 11-76.

LINDER, H.P. 1985. Conspectus of the African species of Restionaceae. Bothalia 15: 387-503.

LINDER, H.P. 1986. A review of the tropical African and Malagasy Restionaceae. Kew Bulletin 41: 99-106.

LINDER, H.P. 1990. A morphological study on the Thamnochortus erectus complex (Restionaceae). South African Journal of Botany 56: 443-449.

LINDER, H.P. 1995. Restio mlanjiensis, a new species of Restionaceae from south-central Africa. Kew Bulletin 50: 623-625.

LINDER, H.P. 2001a. The African Restionaceae. Contributions from the Bolus Herbarium. Cape Town.

LINDER, H.P. 2001b. Two new species of Askidiosperma (Restionaceae) from South Africa. Nordic Journal of Botany 21: 195-199.

LINDER, H.P. 2003. The radiation of the Cape flora, southern Africa. Biological Reviews 78: 597-638.

LINDER, H.P. \& FERGUSON, I.K. 1985. On the pollen morphology and phylogeny of the Restionales and Poales. Grana 24: 65-76.

LINDER, H.P. \& MANN, D.M. 1998. The phylogeny and biogeography of Thamnochortus (Restionaceae). Botanical Journal of the Linnean Society 128: 319-357.

LINDER, H.P. \& VLOK, J.H. 1991. The morphology, taxonomy and evolution of Rhodocoma (Restionaceae). Plant Systematics and Evolution 175: 139-160.

LINDLEY, J. 1836. A natural system of Botany, edn 2. Longman, Rees, Orme, Brown \& Green, London. 
LINNAEUS, C. 1755. Centuria I. Plantarum. In C. Linnaeus, Amoenitates 4: 261-296. Salvii, Stockholm.

LINNAEUS, C. 1767. Systema naturae. Salvii, Stockholm.

LINNAEUS, C. 1771. Mantissa plantarum altera. Salvii, Stockholm.

MADDISON, W.P. 1997. Gene trees in species trees. Systematic Biology 46: 523-536.

MADDISON, W.P. \& MADDISON, D.R. 2003. Mesquite: a modular system for evolutionary analysis, version 2.72 . Website: http://mesquiteproject.org/mesquite/mesquite.html (accessed).

MASTERS, M.T. 1865. Oberservations on the morphology and anatomy of the genus Restio, Linn., together with an enumeration of the South African species. Journal of the Linnean Society (Botany) 8: 211-255.

MASTERS, M.T. 1868. Synopsis of the South African Restiaceae. Journal of the Linnean Society (Botany) 10: 209-279.

MASTERS, M.T. 1874. On the Restiaceae of Thunberg's Herbarium. Journal of the Linnean Society (Botany) 14: 413-421.

MASTERS, M.T. 1878. Restiaceae. In A. De Candolle \& C. De Candolle, Monographiae Phanerogamarum 1: 218-398. Masson, Paris.

MASTERS, M.T. 1885. Supplementary notes on Restiaceae. Journal of the Linnean Society (Botany) 21: 574-594.

MASTERS, M.T. 1897. Restiaceae. In W.T. Dyer, Flora capensis 7: 59-149. Reeve, London.

MASTERS, M.T. 1899. Thamnochortus insignis. The Gardener's Chronicle 25, ser. 3: 242.

MASTERS, M.T. 1900a. Annalen des Kaiserlich-Königlichen Naturhistorischen Hofmuseums, Wien 15: 11.

MASTERS, M.T. 1900b. Restionaceae novae capensis herbarii Berolinensis, imprimis Schlechterianae. Botanische Jahrbücher 29 Beiblatt 66: 1-20.

MCVAUGH, R. 1968. Report of the committee for Spermatophyta. Taxon 17: 85-88.

MOLINE, P.M. \& LINDER, H.P. 2005. Molecular phylogeny and generic delimitation in the Elegia group (Restionaceae, South Africa) based on a complete taxon sampling and four chloroplast DNA regions. Systematic Botany 30: 759-772.

NEES AB ESENBECK, C.G. 1830. Beitrag zur Kenntnis der Familien der Restiaceen im Rücksicht auf Gattungen und Arten. Linnaea 5: 627-666.

NIXON, K.C. 1993. CLADOS. Published privately, New York.
OLIVER, E.G.H. 2000. Systematics of Ericeae (Ericaceae: Ericoideae) species with indehiscent and partially dehiscent fruits. Contributions from the Bolus Herbarium 19: 1-483.

PERSOON, C.H. 1807. Synopsis plantarum. Cramer \& Cotta, Paris \& Tübingen.

PILLANS, N.S. 1921. In H.M.L. Bolus, Novitates Africanae. Annals of the Bolus Herbarium 3,2: 82-85.

PILLANS, N.S. 1922. In H.M.L. Bolus, Novitates Africanae. Annals of the Bolus Herbarium 3,3: 123-146.

PILLANS, N.S. 1928. The African genera and species of Restionaceae. Transactions of the Royal Society of South Africa 16: 207-440.

PILLANS, N.S. 1942. New species of South African Restionaceae. Transactions of the Royal Society of South Africa 29: 339-356.

PILLANS, N.S. 1945. New and hitherto imperfectly known species of African Restionaceae. Transactions of the Royal Society of South Africa 30: 245-266.

PILLANS, N.S. 1952. New and hitherto imperfectly known species of South African Restionaceae. Journal of South African Botany 18: $101-122$

POIRET, J.L.M. 1804. In Lamarck, Encyclopédie méthodique. Botanique, vol. 6. Agasse, Paris.

REBELO, A.G., BOUCHER, C., HELME, N.A., MUCINA, L. \& RUTHERFORD, M.C. 2006. Fynbos Biome. In L. Mucina \& M.C. Rutherford, The vegetation of South Africa, Lesotho and Swaziland. Strelitzia 19. South African National Biodiversity Institute, Pretoria.

ROTTBOELL, C.F. 1772. Descriptiones plantarum rariorum. Möller, Copenhagen.

ROTTBOELL, C.F. 1773. Descriptiones et iconum rariores. Möller, Copenhagen.

SCHELPE, E.A.C.L.E. 1967. The identity of Equisetum capense Burm. f. Journal of South African Botany 33: 155, 156

SPRENGEL, K. 1824. Systema vegetabilium, vol. 1. Dieterich, Göttingen.

STEUDEL, E.G. VON. 1855. Synopsis plantarum glumacearum, vol. 2. Metzler, Stuttgart.

TAYLOR, H.C. 1978. Capensis. In M.J.A. Werger, Biogeography and ecology of southern Africa, vol. 1: 171-229. Junk, The Hague.

THUNBERG, C.P. 1788. Dissertatione de Restione. Dieterich, Gottingen.

THUNBERG, C.P. 1803. Novae species plantarum Capensium, examinatae et descriptae. Phytographische Blatter Gottinger 1: 1-35.

\section{INDEX}

Askidiosperma Steud., 14

albo-aristatum (Pillans) H.P.Linder, 15

alticolum (Esterh.) H.P.Linder, 15

andreaeanum (Pillans) H.P.Linder, 15

capitatum Steud., 15

chartaceum (Pillans) H.P.Linder, 15

delicatulum H.P.Linder, 15

esterhuyseniae (Pillans) H.P.Linder, 15

insigne (Pillans) H.P.Linder, 15

longiflorum (Pillans) H.P.Linder, 15

nitidum (Mast.) H.P.Linder, 15

paniculatum (Mast.) H.P.Linder, 15

rugosum Esterh., 15

Calopsis Beauv. ex Desv., 15, 20

adpressa Esterh., 24

andreaeana (Pillans) H.P.Linder, 24

aspera (Mast.) H.P.Linder, 21

burchellii (Mast.) H.P.Linder, 24

clandestina Esterh., 22

dura Esterh., 24

esterhuyseniae (Pillans) H.P.Linder, 17

filiformis (Mast.) H.P.Linder, 24

fruticosa (Mast.) H.P.Linder, 24

gracilis (Mast.) H.P.Linder, 24

hyalina (Mast.) H.P.Linder, 21

levynsiae (Pillans) H.P.Linder, 21

marlothii (Pillans) H.P. Linder, 24

monostylis (Pillans) H.P.Linder, 17

muirii (Pillans) H.P.Linder, 24

nudiflora (Pillans) H.P.Linder, 22

pulchra Esterh., 21 rigida (Mast.) H.P.Linder, 21

rigorata (Mast.) H.P.Linder, 24

Calorophus

asper (Mast.) Kuntze, 21

burchellii (Mast.) Kuntze, 21

filiformis (Mast.) Kuntze, 24

gracilis (Mast.) Kuntze, 24

Chondropetalum Rottb., 11

Craspedolepis Steud., 15, 17

Dovea Kunth, 11

Elegia $L ., 11$

acockii (Pillans) Moline \& H.P.Linder, 14

aggregata (Mast.) Moline \& H.P.Linder, 14

altigena Pillans, 14

amoena Pillans, 14

asperiflora (Nees) Kunth, 14

atratiflora Esterh., 14

caespitosa Esterh., 14

capensis (Burm.f.) Schelpe, 14

coleura Nees ex Mast., 14

cuspidata Mast., 12

decipiens (Esterh.) Moline \& H.P.Linder, 14

deusta (Rottb.) Kunth, 14

dregeana Kunth, 14

ebracteata (Kunth) Moline \& H.P.Linder, 14

elephantina H.P.Linder, 12

equisetacea Mast., 14

esterhuyseniae Pillans, 14

extensa Pillans, 14

fastigiata Mast., 14

fenestrata Pillans, 14 
Elegia L. (cont.)

filacea Mast., 14

fistulosa Kunth, 14

fucata Esterh., 14

galpinii N.E.Br., 14

grandis (Nees) Kunth, 14

grandispicata H.P.Linder, 14

hookeriana (Mast.) Moline \& H.P.Linder, 14

hutchinsonii Pillans, 14

intermedia (Steud.) Pillans, 14

juncea $L ., 14$

macrocarpa (Kunth) Moline \& H.P.Linder, 14

marlothii (Pillans) Moline \& H.P.Linder, 14

microcarpa (Kunth) Moline \& H.P.Linder, 14

mucronata (Nees) Kunth, 12

muirii Pillans, 14

neesii Mast., 14

nuda (Rottb.) Kunth, 12

persistens Mast., 14

prominens Pillans, 14

racemosa (Poir.) Pers., 14

recta (Mast.) Moline \& H.P.Linder, 14

rigida Mast., 14

spathacea Mast.,14

squamosa Mast., 14

stipularis Mast., 14

stokoei Pillans, 14

tectorum (L.f.) Moline \& H.P.Linder, 12

thyrsifera (Rottb.) Pers., 14

thyrsoidea (Mast.) Pillans, 14

vaginulata Mast., 14

verreauxii Mast., 14

Hypolaena

aspera Mast., 21

burchellii Mast., 21

filiformis Mast., 24

hyalina Mast., 21

mahonii N.E.Br., 8

Ischyrolepis Steud., 15, 24

affinis Esterh., 28

caespitosa Esterh., 27

capensis (L.) Linder, 30

curvibracteata Esterh., 28

feminea Esterh., 26

karooica Esterh., 28

longiaristata Pillans, 26

nana Esterh., 27

nubigena Esterh., 30

papillosa Esterh., 26

pratensis Esterh., 26

rivula Esterh., 26

saxatilis Esterh., 27

sporadica Esterh., 26

unispicata H.P.Linder, 31

wittebergensis Esterh., 28

Lamprocaulis Mast., 11

Leptocarpus

andreaeanus Pillans, 24

asper (Mast.) Pillans, 21

gracilis (Mast.) Pillans, 24

hyalinus (Mast.) Pillans, 21

levynsiae Pillans, 21

membranaceus Pillans, 21

monostylis Pillans, 17

muirii Pillans, 24

nudiflorus Pillans, 22

rigida Mast., 21

rigoratus Mast., 24

Mastersiella hyalina (Mast.) Gilg-Ben., 21

Platycaulos H.P.Linder, 6

acutus Esterh., 8

anceps (Mast.) H.P.Linder, 8

callistachyus (Kunth) H.P.Linder, 8

cascadensis (Pillans) H.P.Linder, 8

compressus (Rottb.) H.P.Linder, 8

depauperatus (Kunth) H.P.Linder, 8

galpinii (Pillans) H.P.Linder \& C.R.Hardy, 8

mahonii (N.E.Br.) H.P.Linder \& C.R.Hardy, 8

subsp. humbertii (Cherm.) H.P.Linder \& C.R.Hardy, 8

subsp. mahonii, 8 major (Mast.) H.P.Linder, 8

mlanjiensis (H.P.Linder) H.P.Linder \& C.R.Hardy, 8 quartziticola (H.P.Linder) H.P.Linder \& C.R.Hardy, 8 subcompressus (Pillans) H.P.Linder, 8

Restio Rottb., 15

acockii Pillans, 18

adpressus (Esterh.) H.P.Linder \& C.R.Hardy, 24

affinis (Esterh.) H.P.Linder \& C.R.Hardy, 28

albotuberculatus H.P.Linder \& C.R.Hardy, 24

alticola Pillans, 22

ambiguus Mast., 6

andreaeanus (Pillans) H.P.Linder \& C.R.Hardy, 24

anomalus H.P.Linder, 26

arcuatus Mast., 22

aridus Pillans, 30

asperus (Mast.) H.P.Linder \& C.R.Hardy, 21

aureolus Pillans, 18

bifarius Mast., 17

bifidus Thunb., 17

bifurcus Nees ex Mast., 18

bolusii Pillans, 18

brachiatus (Mast.) Pillans, 18

brunneus Pillans, 18

burchellii Pillans, 18

caespitosus (Esterh.) H.P.Linder \& C.R.Hardy, 27

calcicola H.P.Linder \& C.R.Hardy, 24

capensis (L.) H.P.Linder \& C.R.Hardy, 30

capillaris Kunth, 18

cedarbergensis H.P.Linder, 29

cincinnatus Mast., 27

clandestinus (Esterh.) H.P.Linder \& C.R.Hardy, 22

coactilis Mast., 28

colliculospermus H.P.Linder, 22

communis Pillans, 22

confusus Pillans, 17

constipatus H.P.Linder, 27

corneolus Esterh., 22

curvibracteatus (Esterh.) H.P.Linder \& C.R.Hardy, 28

curviramis Kunth, 27

cymosus (Mast.) Pillans, 18

debilis Nees, 20

decipiens (N.E.Br.) H.P.Linder, 22

degenerans Pillans, 22

dichotomus L., 30

dispar Mast., 22

distans Pillans, 20

distichus Rottb., 21

distractus Mast., 31

distylis H.P.Linder \& C.R.Hardy, 17

dodii Pillans

var. dodii, 22

var. purpurascens Pillans, 22

durus (Esterh.) H.P.Linder \& C.R.Hardy, 24

duthieae Pillans, 27

echinatus Kunth, 16

egregius Hochst., 17

ejuncidus Mast., 22

eleocharis Mast., 30

elsieae H.P.Linder, 28

esterhuyseniae Pillans, 28

femineus (Esterh.) H.P.Linder \& C.R.Hardy, 26

festuciformis Nees ex Mast., 22

filiformis Poir., 18

foliosus N.E.Br., 11

fragilis Esterh., 22

fraternus Kunth, 28

fuscidulus Pillans, 30

fusiformis Pillans, 18

galpinii Pillans, 8

gaudichaudianus Kunth, 30

var. luxurians Pillans, 30

gossypinus Mast., 28

harveyi Mast., 21

helenae Mast., 30

hyalinus (Mast.) H.P.Linder \& C.R.Hardy, 21

hystrix Mast., 28

implicatus Esterh., 22

impolitus Kunth, 22

inconspicuus Esterh., 22 
Restio Rottb., (cont.)

ingens Esterh., 22

insignis Pillans, 18

inveteratus Esterh., 18

karooicus (Esterh.) H.P.Linder \& C.R.Hardy, 28

laniger Kunth, 31

leptoclados Mast., 30

leptostachyus Kunth, 22

levynsiae (Pillans) H.P.Linder \& C.R.Hardy, 21

longiaristatus (Pillans ex H.P.Linder) H.P.Linder \& C.R.Hardy, 26

luxurians (Pillans) H.P.Linder, 30

macer Kunth, 26

madagascariensis Cherm. var. humbertii Cherm., 8

mahonii (N.E.Br.) Linder subsp. humbertii (Cherm.) H.P.Linder, 8

mahonii (N.E.Br.) Pillans, 8

marlothii Pillans, 27

micans Nees, 17

miser Kunth, 17

mlanjiensis H.P.Linder, 8

monanthos Mast., 30

monostylis (Pillans) H.P.Linder \& C.R.Hardy, 17

montanus Esterh., 22

muirii (Pillans) H.P.Linder \& C.R.Hardy, 24

multiflorus Spreng., 22

nanus (Esterh.) H.P.Linder \& C.R.Hardy, 27

nodosus Pillans, 18

nubigenus (Esterh.) H.P.Linder \& C.R.Hardy, 30

nudiflorus (Pillans) H.P.Linder \& C.R.Hardy, 22

nuwebergensis Esterh., 17

obscurus Pillans, 18

occultus (Mast.) Pillans, 18

ocreatus Kunth, 28

pachystachyus Kunth, 18

paludicola H.P.Linder, 22

paludosus Pillans, 26

paniculatus Rottb., 20

papillosus (Esterh.) H.P.Linder \& C.R.Hardy, 26

papyraceus Pillans, 17

parthenocarpos H.P. Linder, 30

parvispiculus H.P.Linder \& C.R.Hardy, 21

patens Mast., 18

peculiaris Esterh., 22

pedicellatus Mast., 16

perplexus Kunth, 18

perseverans Esterh., 18

pillansii H.P.Linder, 22

praeacutus Mast., 18

pratensis (Esterh.) H.P.Linder \& C.R.Hardy, 26

pulcher (Esterh.) H.P.Linder \& C.R.Hardy, 21

pulvinatus Esterh., 18

pumilus Esterh., 22

purpurascens Nees ex Mast., 22

pygmaeus Pillans, 26

quadratus Mast., 20

quartziticola H.P.Linder, 8

quinquefarius Nees, 20

ramosissimus H.P.Linder \& C.R.Hardy, 24

rarus Esterh., 22

rigidus (Mast.) H.P.Linder \& C.R.Hardy, 21

rigoratus (Mast.) H.P.Linder \& C.R.Hardy, 24

rivulus (Esterh.) H.P.Linder \& C.R.Hardy, 26

rottboellioides Kunth, 26

rudolfii (Pillans) H.P.Linder \& C.R.Hardy, 24

rupicola Esterh., 18

sabulosus Pillans, 26

saroclados Mast. in A.DC., 22

saxatilis (Esterh.) H.P.Linder \& C.R.Hardy, 27

scaber Mast., 22

scaberulus N.E.Br. 22

schoenoides Kunth, 27

secundus (Pillans) H.P.Linder, 22

sejunctus Mast., 22

setiger Kunth, 28

sieberi Kunth, 30

similis Pillans, 20

singularis Esterh., 22

sporadicus (Esterh.) H.P.Linder \& C.R.Hardy, 26

stereocaulis Mast., 16

stokoei Pillans, 22

strictus N.E.Br., 22 strobilifer Kunth, 18

subgen. Calopsis (Beauv. ex Desv.) H.P.Linder \& C.R.Hardy, 20

subgen. Craspedolepis (Steud.) H.P.Linder \& C.R.Hardy, 17

subgen. Eremorestio H.P.Linder \& C.R.Hardy, 20

subgen. Ischyrolepis (Steud.) H.P.Linder \& C.R.Hardy, 24

subgen. Locapsis H.P.Linder \& C.R.Hardy, 23

subgen. Pendulostemon H.P.Linder \& C.R.Hardy, 17

subgen. Restio, 21

subgen. Simplicaulos H.P.Linder \& C.R.Hardy, 16

subgen. Varirestio H.P.Linder \& C.R.Hardy, 18

subtilis Nees ex Mast., 17

subverticellatus (Steud.) Mast., 30

tenuispicatus H.P.Linder \& C.R.Hardy, 24

tenuissimus Kunth, 26

tetragonus Thunb., 20

triflora Rottb., 30

triticeus Rottb., 22

tuberculatus Pillans, 22

unispicatus (H.P.Linder) H.P.Linder \& C.R.Hardy, 31

vallis-simius H.P.Linder, 22

venustulus Kunth, 31

verrucosus Esterh., 22

versatilis $H$. P Linder, 22

vilis Kunth, 28

villosus H.P.Linder \& C.R.Hardy, 22

vimineus Rottb., 24

virgeus Mast., 28

wallichii Mast., 26

wittebergensis (Esterh.) H.P.Linder \& C.R.Hardy, 28

zuluensis H.P.Linder, 22

zwartbergensis Pillans, 22

Rhodocoma Nees, 10

alpina H.P.Linder \& Vlok, 11

arida H.P.Linder \& Vlok, 11

capensis Nees ex Steud., 11

foliosa (N.E.Br.) H.P.Linder \& C.R.Hardy, 11

fruticosa (Thunb.) H.P.Linder, 11

gigantea (Kunth) H.P.Linder, 11

gracilis H.P.Linder \& Vlok, 11

vleibergensis H.P.Linder, 11

Schoenus capensis L., 30

Soroveta H.P.Linder \& C.R.Hardy, 6

ambigua (Mast.) H.P.Linder \& C.R.Hardy, 6

Staberoha Kunth, 8

aemula (Kunth) Pillans, 9

banksii Pillans, 9

cernua (L.f.) Dur. \& Schinz, 9

distachyos (Rottb.) Kunth, 9

multispicula Pillans, 9

ornata Esterh., 9

remota Pillans, 9

stokoei Pillans, 9

vaginata (Thunb.) Pillans, 9

Thamnochortus P.J.Bergius, 9

acuminatus Pillans, 10

amoena H.P.Linder, 10

arenarius Esterh., 10

bachmannii Mast., 10

cinereus H.P.Linder, 10

dichtomus (L.) Spreng., 30

dumosus Mast., 10

ellipticus Pillans, 10

erectus (Thunb.) Mast., 10

fraternus Pillans, 10

fruticosus P.J.Bergius, 10

glaber (Mast.) Pillans, 10

gracilis Mast., 10

guthrieae Pillans, 10

insignis Mast., 10

karooica H.P.Linder, 10

levynsiae Pillans, 10

lucens (Poir.) H.P.Linder, 10

muirii Pillans, 10

nutans (Thunb.) Pillans, 10

obtusus Pillans, 10

paniculatus Mast., 10

papyraceus Pillans, 10

pellucidus Pillans, 10

platypteris Kunth, 10

pluristachyus Mast., 10 
Thamnochortus P.J.Bergius (cont.)

pulcher Pillans, 10

punctatus Pillans, 10

rigidus Esterh., 10 schlechteri Pillans, 10

spicigerus (Thunb.) Spreng., 10

sporadicus Pillans, 10

stokoei Pillans, 10 